\title{
Managing innovation: The role of collateral*
}

\author{
Yifei Mao \\ Kelley School of Business \\ Indiana University \\ yifmao@indiana.edu \\ (812) 855-3476
}

This version: January, 2015

\footnotetext{
*I am indebted to my co-chairs, Matt Billett and Xuan Tian, for their invaluable guidance, encouragement, and support. I am also deeply grateful to my committee members Jeffrey Fisher, Craig Holden, Gregory Udell, and Xiaoyun $\mathrm{Yu}$ who have been generous with their time and provided wonderful help. I also thank Michael Brennan, James Brown, Phil Dybvig, Espen Eckbo, Mariassunta Giannetti, Thomas Hellmann, Shiyang Huang, Josh Lerner, David Robinson, Per Stromberg, David Thesmar, Charles Trzcinka, Jun Yang, Yao Zeng, and all participants in the seminar at Indiana University, Institute of Financial Studies, the NBER Entrepreneurship Research Boot Camp, and SIFR Conference on Entrepreneurship and Innovation for helpful comments and suggestions. I thank David Sraer and Diego Garcia who shared their data with me. Remaining errors and omissions are my own responsibility.
} 


\title{
Managing innovation: The role of collateral
}

\begin{abstract}
This paper studies how credit constraints impact the management of corporate innovation. Specifically, my experiment exploits exogenous variations in the collateral value of real estate assets as shocks to firms' credit constraints. Building on this experiment, I find evidence that higher collateral value increases the quantity, quality and novelty of innovation. I show that: (1) increase in collateral value leads to more patent filings, with each patent on average receiving more citations, citing patents from a wider range of industries, and more likely to be in industries different from the parent firm; (2) in response to collateral shocks, firms restructure their innovation strategies through different channels such as internal research and development (R\&D), acquisitions of innovative targets, and corporation venture capital (CVC) investment equity investment in startups by incumbent firms; (3) the effect of collateral shocks on innovation is more pronounced for firms that are ex-ante credit constrained, but mitigated if firms are located in Metropolitan Statistical Area (MSA) areas with high local real estate price volatility.
\end{abstract}

Keywords: Innovation management, Collateral, Real Estate, R\&D, Corporate Venture Capital JEL classification: O31, O32, G34, G24, R30 


\section{Introduction}

Since Schumpeter, existing literature has well established the importance of technological innovation as a critical driver to a nation's long-term economic growth (Solow (1957)) and firms' competitive advantage (Porter (1992)). Nevertheless, how to effectively finance and promote innovation remains challenging for most countries and organizations ((Hall and Lerner (2010), Kerr and Nanda (2014))). The financial contracting environment surrounding innovation is particularly challenging. Specifically, innovation is associated with severe agency problems, as it entails highly risky and long-term investment, often in intangible assets such as human capital, and results in unpredictable outcomes (Holmstrom (1989)).

A growing literature explores the role that external capital market plays in impacting firm-level innovation. ${ }^{1}$ In particular, there has been a lot of debate on the bright and dark sides of different financial contracting instruments such as debt and equity in terms of spurring innovation (e.g., Aghion et al. (2013), Amore et al. (2013), Bernstein (2014), Brown et al. (2009, 2012), Hsu et al. (2014), Robb and Robinson (2014)). The focus of these studies has been on how incentive problems arising from these different contracting environments impact the innovation outputs. Recently, the nature of innovative projects (e.g., incremental vs. radical innovation) impacted by financing conditions begins to receive more research attention (Akcigit and Kerr (2012), Chava et al. (2013), Gao et al. (2014), Nanda and Nicholas (2014), Nanda and Rhodes-Kropf (2010, 2013)). However, the understanding on the precise mechanism and channels behind the relationship between external finance and innovation is still limited.

The goal of this paper is to deepen the understanding regarding the financing and innovation relationship, by identifying both a mechanism and specific channels through which access to finance affects innovation and by quantifying the impact of access to credit on shaping the distribution of innovative investment. To this end, I focus on corporate innovation. Corporations are important contributors to technological innovation economy wide. For instance, they generate a vast majority of patents in the U.S. ${ }^{2}$ Further, in the pusuit of long-term growth, corporations employ a spectrum of strategies from internal to external innovation, and from incremental to radical innovation, which render it a rich setting for examining various channels

\footnotetext{
${ }^{1}$ For surveys on research regarding financing and innovation, see Hall and Lerner (2010), and Kerr and Nanda (2014).

${ }^{2}$ Based on National Bureau of Economics Research (NBER) patent citation database and Hall, Jaffe, and Trajtenberg (2001), the patents filed by corporations are around $75 \%$ of all patents filed in the economy.
} 
of innovation. The incentives and contracting issues surrounding these different organizational vehicles of innovation have been well discussed by the literature on innovation management (Aghion and Tirole (1994), Fulghieri and Sevilir (2009), Matthews and Robinson (2008), Robinson (2008), Stein (1997)).

In the attempt to investigate how finance affects corporate innovation, I examine innovation budget allocation on channels including: $R \& D$, acquisitions, and corporate venture investment. The $\mathrm{R} \& \mathrm{D}$ done in corporate laboratories has been a dominant feature in the landscape of corporate innovation, and it is generally regarded as an organic and internal way of conducting innovation. In addition to in-house $R \& D$, another way for corporations to advance innovation is through external acquisitions of innovative targets (Bena and Li (2013), Higgins and Rodriguez (2006), Sevilir and Tian (2013), Zhou (2014)). Furthermore, as pointed out by Lerner (2012), corporations might motivate innovation through a "hybrid" model - a corporate venture capital (CVC) program that combines features of corporate research laboratories and venture-backed start-ups (Chemmanur et al. (2013), Chesbrough (2002), Chesbrough and Tucci (2004), Dushnitsky and Lenox (2005, 2006), Gompers and Lerner (2000)). ${ }^{3}$

Several empirical challenges face the identification of how external financing cost affects innovation. First, external cost of finance is unobservable ex ante and therefore is difficult to quantify. Second, innovation decisions are made endogeneous with company and market characteristics, including financial decisions of a firm. The endogeneity makes it difficult to establish the causal effect external financing cost may have on innovation, as well as the channels through which such an effect occurs. To address the first challenge, I use the market value of commercial real estate owned by firms as a measure for access to credit. To overcome the endogeneity problems, I employ identification strategies that make use of the exogeneous variations in the real estate value.

To quantify access to credit of a corporation, it is natural to use the commercial real estate market. First of all, real estate is an important asset for publicly traded innovative firms and its price variations lead to large swings of firm asset value. During the sample period of 1993 to 2009 , the market value of commercial real estate accounted for 15 percent of innovative firms'

\footnotetext{
${ }^{3}$ Corporate venture capital (CVC) investment is minority equity investment in entrepreneurial start-ups by incumbent firms. Corporations usually structure CVC programs as corporate subsidiaries. For a thorough discussion of CVC, see Gompers and Lerner (2000), Lerner (2012), Dushnitsky and Lenox (2005, 2006).
} 
total market value. ${ }^{4}$ Secondly, real estate is an important form of collateral. Commercial real estate usually has a high loan-to-value ratio (median of 82 percent of value according to Benmelech et al. (2005)). Compared to other types of collateral such as inventory and accounts receivables, real estate is easily redeployable and more likely to be pledged against debt. Finally, even in the presence of a first mortgage, a second lien could still be placed on real estate (Brueggeman and Fisher (2010)). It is particularly important in the setting of this paper, since it allows a firm to take advantage of the increase in real estate value to issue more debt.

While commercial real estate potentially affects the collateral value of a firm, prior studies provide some intuition of how collateral pledging might influence innovation. In the presence of contract incompleteness, collateral increases a firm's borrowing capacity by allowing lenders to seize the pledged assets in case of bankruptcy. ${ }^{5}$ Therefore, an increase in collateral value eases financing ex ante. Furthermore, the nature of innovation reinforces the role collateral plays in contracting. As summarized by Kerr and Nanda (2014), innovation is associated with high uncertainty (Knight (1921)), extremely skewed returns (Scherer and Harhoff (2000)), high information asymmetry (Holmstrom (1989)), and intangible assets (Hall and Lerner (2010)). These traits lead to high agency costs of debt. Meanwhile, it is difficult for debt holders to monitor the innovative process, since innovation does not provide many verifiable performance signals (Manso (2011)). While collateral pledging can be used to mitigate underinvestment problems ((Stulz and Johnson (1985), Bao and Kolasinski (2014)), it could become especially important in reducing the agency costs of debt for innovators. This is partially due to the fact that collateral pledging is a debt contracting mechanism that does not heavily rely on monitoring techniques to reduce agencies costs. ${ }^{6}$

In order to extract exogenous variations in the market value of real estate collateral, I adapt the identification approach developed in prior studies (Chaney, Sraer and Thesmar (2012), Cvijanovic (2014)). More precisely, I take firm-specific initial real estate holdings at the

\footnotetext{
${ }^{4}$ In this paper, innovative firms are defined as firms with patenting activities.

${ }^{5}$ See, Almeida and Campello (2007), Almeida, Campello, and Liu (2006), Barro (1976), Bernanke and Gertler (1989), Benmelech and Bergman (2009), Berger and Udell (1995), Boot, Thakor, and Udell (1991), Chan and Thakor (1987), Gan (2007), Jimenez et al. (2006), Rampini and Viswanathan (2013), Stiglitz and Weiss (1981), Shleifer and Vishny (1992), Tirole (2005), etc.

${ }^{6}$ As an increase in the collateral value improves the overall credit access of a firm, it is worth noting that there are two ways for firms to finance innovation by collateral pledging. First, firms may directly finance innovation projects with debt secured by real estate. Second, firms can employ secured debt to finance ordinary investment, and divert more internal resources to innovation expenses. Here, I do not distinguish between these two alternative methods, since either case is consistent with the hypothesis that access to finance affects innovation.
} 
beginning of the sample period, and then identify the real estate value variations stemming from local commercial real estate prices changes (at Metropolitan Statistical Area (MSA) level). The identification comes from two sources. First, I compare innovation of land-holding firms across MSA areas with different local real estate prices. This allows me to abstract from aggregate economic fluctuations that might affect innovation of firms. Second, within an MSA area, I compare innovation of firms with different levels of real estate holdings. Because firms lose or gain collateral value proportionate to their real estate holdings prior to the price shocks, the preshock real estate holdings, if randomly assigned, provide an exogenous measure of the change in collateral value (Gan (2007)). This method allows me to control for local economic shocks that could be correlated with innovation.

There are two sources of potential endogeneity: (1) real estate holdings might be endogeneous decisions; (2) local real estate prices might be correlated with investment opportunities that also drive innovation in the area. To mitigate the first concern, I control for the observable determinants in the real estate ownership, including size, location, profitability, age, and industry of a firm. The second concern is that different areas may be hit by different price shocks endogenous to local innovation activity. To address the issue, I instrument local real estate prices by the interaction between local land supply elasticity and national occupancy rate. The intuition behind the instrument is straightforward: for one unit demand shock to commercial real estate (proxied by occupancy rate), areas with lower land supply elasticity would experience a larger appreciation in commercial real estate prices because housing supply can not be expanded easily in the area (Mian and Sufi (2011), Glaeser, Gyourko, and Saiz (2008)). Local land supply elasticity is a measure of land availability at the MSA level developed by Saiz (2010), capturing both geographical constraints and zoning regulations. Occupancy rate is the source of demand from tenants who rent the space that leads to returns and price increases for the space owned by investors.

My main finding is that collateral value is significantly positively correlated with corporate innovation in the subsequent five years after the real estate shock. The relationship between real estate collateral value and innovation is statistically significant and economically large. A one-standard deviation increase in real estate value increases patents filed and granted in the subsequent five years (citations received by patent in the subsequent five years) by 14 (13) percent of its standard deviation. Comparing between the results based on the OLS and IV 
analyses, it appears that OLS biases the effect of real estate value on firm innovation upward due to endogeneity. This observation suggests that certain omitted variables (such as investment opportunities) simultaneously make firms more innovative and more likely to experience an increase in real estate price. Once I use the IV to clean up the correlation between real estate collateral and the omitted variables, the endogeneity of VC staging is largely mitigated and the coefficient estimate decreases. However, the effect still remains positive and significant, suggesting a nontrivial effect of collateral value on innovation.

In addition to the quantity of innovation measured by number of patents and the quality of innovation measured by citations per patent, I examine the novelty of innovation outcome, as measured by originality score and generality score of patent filings. I observe an increase in the originality score starting from the second year after collateral shock, suggesting that filed patents are on average citing a wider range of industries. Finally, I compute the ratio of patents in industries different from the SIC 2-digit industry of the parent firm. The results suggest there is also an increase in the patents in different technological industries following collateral value increases. It implies that firms are expanding into industries with different technologies. Taken together, patent-based metrics suggest that firms are taking more path-breaking, radical innovation as a response to a collateral value increase.

To understand the channels through which patenting activities are affected, I conduct an analysis of underlying channels. I find that firms increase their innovative investment through all three channels as a response to real estate value appreciation. The percentage increases in the three channels are different. For a one-standard deviation increase in the collateral value, acquisitions of innovative targets increase by 30 percent, followed by CVC investment (29 percent), and then $R \& D$ investment (16 percent). It is probably because $R \& D$ has the highest adjustment cost (Hall and Lerner (2010)) and lowest information asymmetry among the three types of investment.

I also trace the deal characteristics of acquisitions and corporate venture investment. I find that following collateral value increases, the acquisitions are more likely to be cash-based. The targets purchased in general have more patent filings and citations per patent prior to the acquisition. Furthermore, these targets are more likely to be in industries that are different from the acquirer. For corporate venture investment, there are also some interesting dynamics going on. Following collateral value increase, firms tend to invest in younger entrepreneurial start-ups 
at earlier rounds. These start-ups also have a higher likelihood to be acquired ex post, and they are more likely to be in industries different from the incumbent firms. The evidence from the innovative investment channels is consistent with the patenting outcomes. It suggests that firms are increasing the quantity, quality and the riskiness of innovation, while expanding into different industry domains.

To further refine the understanding of the effects of collateral shocks on innovation, I explore how real estate value affects innovation differently in the cross section. If real estate is pledged as collateral and mitigates financing constraints, firms subject to higher information asymmetry and agency problems ex-ante should experience larger shifts in innovation as a response to real estate price variation. However, if there is high historical local real estate price volatility, then firms are less likely to increase innovation following collateral value appreciation. In subsample tests, I indeed find that the variation in innovation is more pronounced in firms with more secured debt outstanding, higher credit constraints, and lower historical real estate price volatility. The above cross-sectional tests further lend credence to causal inferences of a positive effect of real estate collateral on corporate innovation. My findings are also robust to various regression and sample specifications.

This paper is the first, of which I am aware, to empirically identify both the underlying channels (R\&D, acquisitions, CVC investment) and a mechanism (collateral pledging) behind the financing and innovation link documented in previous studies. Overall, my findings indicate that collateral value not only improves the innovation rate of public firms in terms of quantity and quality, but also changes the trajectory of innovation away from more incremental innovation to experimental and radical innovations. These effects are more pronounced for firms that are ex-ante credit-constrained, while the effects are mitigated if the variation in the collateral value is likely to be temporary (measured by a high local commercial real estate price volatility).

The remainder of the paper is organized as follows. Section 2 discusses the related literature. Section 3 describes sample construction and reports summary statistics. Section 4 demonstrates the research design. Section 5 presents the baseline results on patenting activities. Section 6 presents results on underlying channels through which collateral shocks affect patenting activities. Section 7 reports cross-section results. Section 8 discusses robustness checks. Section 9 concludes. Variable definitions are in the Appendix. 


\section{Related literature}

This paper contributes to several strands of literature. First, at the broadest level, this paper is related to the literature on finance and investment. As Jensen and Meckling (1976) and Myers (1977) argue, with risky debt outstanding and the separation of ownership and management, managers have incentives to under- and overinvest in future growth opportunities, giving rise to the agency cost of debt. Stulz and Johnson (1985) argue that secured debt can alleviate the "debt-overhang" problems as documented in Myers (1977). While the agency cost could be particularly severe in innovative firms due to the nature of innovation (Homstrom (1989)), I test whether collateral pledging boosts innovation in this paper.

Furthermore, this paper is the first one that shows how the external capital market affects within-firm capital allocation, through the lens of innovation budgets. Instead of using a simplified representation of innovation by either patents or R\&D, I investigate three intermediate channels through which a firm increases its innovation budgets: in-house R\&D, corporate venture capital investment, and acquisitions of innovative targets. While theory suggests that firms can obtain innovation by acquiring targets that are more efficient at innovation (Aghion and Tirole (1994)), empirical studies confirms that acquisitions create synergies for innovation (Bena and Li (2013), Sevilir and Tian (2012)). In addition to acquisitions, corporate venture capital investment has also been shown as a way to source external knowledge (e.g. Chesbrough (2002), Chemmanur, Loutskina, and Tian (2013), Dushnisty and Lenox (2005, 2006), Gompers and Lerner (2000), Gompers (2002), Lerner (2012), etc.). While previous literature has explored the relations between each channel and innovation outcomes, I fill a gap in the literature by investigating how the cost of external finance affects allocation of the innovation budgets through these channels ex ante.

Second, this paper contributes to the literature on financial constraints and innovation. Prior studies recognize well the difficulty of financing innovation due to severe information and agency problems (Hall and Lerner (2010)). Focusing on the 1990s R\&D boom, the seminal work of Brown et al. (2009) uncovers that finance matters for R\&D and economic growth, while Brown et al. (2012) show that access to internal and external equity finance matters a lot for R\&D, especially in firms that are likely to face financing constraints. However, these studies rely on standard investment-cash flow methods, which are likely to be subject to bias in estimations. I use an "ideal" experiment, in which firms are hit by funding shocks independent of investment 
opportunities, to examine the causal effect of credit constraints on innovation. By employing shocks to the borrowing capacity exogenous to a firm's investment opportunities, I am able to document a causal link.

In addition to establishing the causality between access to finance and innovation, this paper also looks into the forms of innovation (incremental vs. radical innovation). Nanda and Rhodes-Kropf $(2013,2014)$ argue that lower financing risk spurs radical innovation. They test the hypothesis in the setting of a hot market for venture capital investment, and argue that hot market lowers the experimentation cost at early stages and allosw investors to make riskier and more novel investments. In this paper, I examine the hypothesis in the setting of real estate market and corporate innovation, and I find consistent results there.

In particular, this paper is closely related to an emerging literature on credit financing and innovation. It is often argued that the structure of a debt contract could be ill-suited to finance innovation, since creditors do not share upside returns of projects while innovative investment is highly risky with skewed returns (e.g. Atnassov, Nanda, and Seru (2007), Stiglitz (1985)). However, debt financing may also enjoy several advantages over equity financing. While equity financing requires information disclosure that might provide sensitive information to competitors (e.g. Bhattacharya and Ritter (1983), Maksimovic and Pichler (2001)), private debt financing does not share this concern. In addition, short-term pressure from public markets accompanying equity financing often exacerbates managerial myopia and is hostile to innovation (e.g. Graham, Harvey, and Rajgopal (2005), He and Tian (2013)), while the problem is not of concern for debt with a long maturity structure.

Recently, many studies show that bank financing and competition facilitated by deregulation promote innovation (e.g. Amore, et al. (2013), Chava et al. (2013), Cornaggia et al. (2014), Hombert and Matray (2013), Benfratello et al. (2008)). Moreover, Robb and Robinson (2014) show that new entrepreneurial firms heavily rely on external debt financing, which is surprisingly opposite to common beliefs. One reason could be that major creditors such as banks with lending expertise are better at evaluating projects, monitoring the firm, and collecting significant soft information about the firms, and hence promote innovation. Mann (2014) shows a direct channel through which credit financing spurs innovation, i.e. using s patent as collateral. Taken together, more studies begin to acknowledge the positive effects of debt financing on innovation by start-ups and mature firms. This paper is consistent with this line of studies in the 
sense that I also show a positive effect of credit financing on innovation, and the difference is that I focus on the micro channel through real estate collateral. With real estate value appreciation, a firm could pledge collateral for debt with longer maturity (Benmelech, Garmaise, Moskowitz (2005), Shleifer and Vishny (1992)) and less restrictive covenants protections (Cvijanovi (2014)), which is especially conducive to innovation.

Third, this paper speaks to the literature on firm boundaries and corporate resource allocation. This line of studies has mainly discussed the "bright side" and "dark side" of internal capital markets, and has implications about the optimal organizational structures of a firm (e.g., Hadlock et al. (2001), Lerner and Stromberg (2011), Matvos and Seru (2014), Robinson (2008), Schafstein and Stein (2000), Seru (2014), Stein (1997, 2003)). Instead of investigating the expost impact of different organizational forms, this paper investigates the ex-ante effect of credit financing on a firm's capital-allocation on investment portfolios.

Finally, this paper is related to the literature that investigates the impact of real estate on real margins such as financial contracts (Bemelech et al. (2005)), capital expenditure (Gan (2007), Chaney et al. (2012)), financial margins such as leverage (e.g. Cvijanovic (2014), Lin (2014), Mian and Sufi (2011)), capital structure (Rampini and Viswanthan (2013)), cash holdings (Chen, Harford, and Lin (2013)), entrepreneurship (Adelino, Schoar, and Severino (2014)), innovation outcome (Cao et al. (2014)), and others. This paper contributes to this line of studies by examining a firm's resource allocation as a response to shocks from the commercial real estate market through the lens of three innovation channels.

\section{Data and sample characteristics}

\subsection{Sample selection}

The sample examined in this paper includes U.S. listed corporations during the period of 1993-2009. To construct the sample, I start from COMPUSTAT firms in 1993 with non-missing total assets, and then I merge the National Bureau of Economics Research (NBER) patent citation data with the Compustat firm sample using a bridge file provided by the NBER database in which GVKEY is the common identifier. I exclude public firms from consideration if they do not have patent information documented by the NBER patent database. Then I select firms whose headquarters are located in the United States and exclude from the sample firms operating in the finance, insurance, real estate, construction and mining industries. I also require firms to 
have available data every consecutive year as they appear in the sample, and appear at least three consecutive years in the sample. This leaves me with a sample of 1,633 firms, and 18,312 firmyear observations.

\subsection{Variable construction}

\subsubsection{Measuring innovation}

To measure the output of innovation, I follow the standards of literature and use patents (e.g., Acharya et al. (2014), Aghion et al. (2013), Nanda and Rhodes-Kropf (2013)). There are different types of patents, including design patent, plant patent, utility patents, and others. ${ }^{7}$ For the purpose of the study, I restrict my attention to utility patents, which appear to be the most relevant measure of innovation. As a matter of fact, utility patents are called "patents for invention". According to US Patent and Trademark Office (USPTO), approximately 90\% of the patent documents issued by the in recent years have been utility patents.

I compile patent citation information from several datasets. First, I extract annual patent and citation data from the latest version of the NBER patent database, which provides information on all patents granted by the US Patent and Trademark Office (USPTO) over the period of 1976-2006. Second, Since NBER database does not provide information about patents after 2006, I use patents granted over the period of 2007-2009 provided by Kogan et al. (2012). ${ }^{8}$ Finally, I attach to patents from Kogan et al. (2012) information about citations over the period of 2007-2009 using the Harvard Business School (HBS) patent and inventor database. ${ }^{9}$

Based on the information collected, I construct three measures. The first measure is a firm's number of patent applications filed in a year that are eventually granted. It is argued that application year better captures the actual time of innovation rather than the grant year (Grilliches, Pakes and Hall (1988)). In addition, when a patent is associated with multiple assignees in different firms, I evenly distribute the patent to each firm. Though straightforward to compute, the number of patents does not tell one the impact of them. Hence, I construct a second measure capturing the importance of each patent by counting the number of citations each patent receives in subsequent years.

\footnotetext{
${ }^{7}$ For a detailed description of each type of patent, refer to the USPTO website http://www.uspto.gov/web/offices/ac/ido/oeip/taf/patdesc.htm.

${ }^{8}$ The database constructed by Kogan et al. (2012) is available at https://iu.box.com/patents.

${ }^{9} \mathrm{HBS}$ database is available at http://dvn.iq.harvard.edu/dvn/dv/patent.
} 
However, patent and patent citations are subject to truncation bias. There are two types of bias. First, there is a decrease in the number of patents observed in the last few years of sample period (e.g., 2005 and 2006) in the NBER patent database. It is because patents appear in the database only after they are granted, and on average there are two years average between the application year and patent granting year. Many patent applications filed in the end of the sample period are still under review and have not been granted by 2006. Following Hall, Jaffe and Trajtenberg (2001), I adjust patent counts using the "weight factor" computed from the application-grant empirical distribution. Second, the citation counts observed in the NBER database are only collected till 2006, though patents keep receiving citations over a long period of time. Following Hall, Jaffe and Trajtenberg (2001), I adjust the citation counts using the shape of the citation-lag distribution.

Besides number of patents and citations per patent, I construct two citation-based measures following Hall, Jaffe and Trajtenberg (2001) and Trajtenberg, Henderson, and Jaffe (1997): patent originality and patent generality. ${ }^{10} \mathrm{~A}$ high originality score of patents indicates that patents cite patents from a wide range of technological fields. A high generality score of patents indicates that the citations of the patent are spread over a large number of technological fields. Both originality and generality measures have been used by the literature as proxies for the novelty of patents, and the extent to which firms are risk-taking or conservative in their innovation strategy (Acharya and Xu (2013), Lerner et al. (2011), Nanda and Nicholas (2014)).

Finally, I measure industry distribution of patents. I define patents that are in a parent firm's main two-digit SIC industry as related patents, and patents that are not in a parent firm's main two-digit SIC industry as unrelated patents. However, USPTO adopts a patent classification system that assigns patents to three-digit technology classes that are based on technology categorization, instead of SIC industry membership based on final product categorization. To convert patents in each technology class to two-digit SIC codes, I use a concordance table that connects most USPTO technology classes to two-digit SIC codes constructed in Hsu, Tian, and $\mathrm{Xu}$ (2014). The scope (diversification) of a patent is the ratio of number of related patents to total number patents of a firm in one year.

\footnotetext{
${ }^{10}$ Refer to Appendix for definitions of generality and originality.
} 


\subsubsection{Measuring real estate values}

I measure firm-level real estate holdings using COMPUSTAT data, and I also obtain commercial real estate prices and national occupancy rate from a proprietary database. ${ }^{11}$

The construction of real estate variables closely follows Chaney, Sraer and Thesmar (2012). First, I define real estate assets of a firm as the summation of three major categories in $1993^{12}$ : Buildings, Land and Improvement, and Construction in Progress. I also subtract the book value of leases from these three items, to make sure the value I am capturing is real estate owned by the firm. Since these assets are not marked to market but valued at historical cost, I need to recover their market value. The procedure goes as follows. First, I estimate the average age of buildings for each firm base. I compute the proportion of the original value of a building claimed as depreciation by counting the ratio of the accumulated depreciation of buildings to the historic cost of buildings. Based on a depreciable life of 40 years, the average age of buildings is 40 multiplied by the proportion. Then I estimate the market value of a firm's real estate assets for each year as inflating their historical cost at the year the buildings were established by state or MSA level commercial real estate inflation after 1975, and CPI inflation before 1975.

One caveat is in calculating the real estate values I made two assumptions here. The first assumption is that firm's real estate assets are located in the same state where the firm's headquarter is located at. It is because COMPUSTAT does not provide the geographic location of all the real estate held by the firm, but only the headquarter location. ${ }^{13}$ The second assumption is that the firms do not repurchase or sell real estate after 1993. Though it might add noise to the analysis, it also avoids endogeneity between real estate purchases and investment opportunities.

\subsubsection{Measuring acquisitions}

I retrieve acquisitions of public firms in my sample from the SDC M\&A database, excluding events that are not acquisitions of a majority of interest of the target's stock. Specifically, I exclude spinoffs, recapitalizations, self-tenders, exchange offers, repurchases,

\footnotetext{
${ }^{11}$ I thank Dr. Jeffrey Fisher for providing me with this database.

12 The reason I pick 1993 is because the accumulated depreciation on buildings is no longer available in COMPUSTAT after 1993, and I need this variable to recover the real estate value.

${ }^{13}$ I use the geographic distribution data from Garcia and Norli (2012) to examine the robustness of results. In particular, in unreported regressions, I construct a relative exposure of each firm to state-level real estate market. The relative exposure to real estate market is computed as the average of real estate prices across different states weighted by a firm's operation exposure to each state in a year. I find that this measure of real estate market exposure positively and significantly affects innovation outputs. The results are available upon requests.
} 
minority stake purchases, acquisitions of remaining interest, and privatizations, while I include leveraged buyouts, and tender offers. For each firm in my sample, I also compute its annual volume and number of M\&A transactions, by aggregating the individual M\&A deals taken by the firm in a year. However, one concern is that simply aggregating all acquisition deals together might include too much noise from acquisition deals, which do not serve the purpose of promoting the acquirers' innovation. To address the concern, I filter the sample by only including targets, that generate at least one patent prior to acquisition. In order to determine whether the target and the parent firm are in the same industry, I trace the SIC industries of targets.

\subsubsection{Measuring corporate venture capital investment}

To identify CVC investors, I start from the universe of VC investors in the VentureXpert database. I only include those VC investors that are identified as "Corporate Subsidiary or Affiliate" and "Corporate Venture Program" in the VentureXpert database. Then I manually identify VCs with a unique corporate parent. ${ }^{14} \mathrm{I}$ also retrieve all investment information for these CVC investors from the VentureXpert. From year 1990 and 2010, I identify 426 distinct CVC programs which are affiliated with 385 publicly traded parent. ${ }^{15}$ Finally, $127 \mathrm{CVC}$ programs enter into the regression analysis, since some of the parent firms of CVC programs have missing real estate prices, or do not fit sample filtering process described in section 3.1.

I also measure whether the entrepreneurial start-up invested by the corporate venture capital program is in the same industry with the incumbent firm. A practical difficulty, however, is that these start-ups are typically not associated with a SIC code since they are not yet publicly traded companies. Rather, they are associated with a proprietary industry classification scheme in VentureXpert. I manually assign a 2-digit SIC to each startup following the method introduced in Dushnitsky and Lenox (2005). Basically, the idea is to generate a mapping table between SIC code and VentureXpert industry classification scheme, by using IPO firms that are associated with both classifications. ${ }^{16}$ Then, I utilize this mapping table to assign 2-digit SIC codes to

\footnotetext{
${ }^{14}$ Basically, I use information searched on GOOGLE to identify the CVC and what its corporate parent is. Then I use COMPUSTAT to find the GVKEY identifier of the corporate parent.

${ }^{15}$ Some firms have more than one corporate venture capital programs.

${ }^{16}$ Refer to page 623 of Dushnitsky and Lenox (2005) for details.
} 
entrepreneurial ventures. The CVC investment is considered as being in the industry different from the parent firm when the venture is in the same SIC 2-digit industry with the parent firm. ${ }^{17}$

\subsubsection{Measuring control variables}

I construct a vector of corporate and industry characteristics to control for factors that affect an IPO firm's innovation output. Following the innovation literature, I control for a vector of innovation variables for firm $i$ over its fiscal year t. Control variables include cash flow (income before extraordinary items and depreciation and amortization (Kaplan and Zingales (1997) plus R\&D), firm size (the natural logarithm of net sales), firm age (the natural logarithm of number of years since the firm appears in COMPUSTAT), profitability (ROA), asset tangibility (net PPE scaled by total assets), leverage, growth opportunities (Tobin's Q), industry concentration (the herfindahl index based on sales), and institutional ownership (Aghion et al. (2013)). Since product market competition might have a non-linear effects on innovation outputs (Aghion et al. (2005)), I include the squared herfindahl index in the controls. I provide detailed descriptions about variable definition in the Appendix.

\subsubsection{Summary statistics}

To minimize the effect of outliers, I winsorize all independent variables at the $1^{\text {st }}$ and $99^{\text {th }}$ percentiles. Table 1 provides summary statistics of the variables. Panel A presents the firm-year level descriptive statistics used in this study at the firm-year level. For a median firm in the entire sample, the book value of real estate represents 9 percent of the book value of assets, which is a sizable fraction of the tangible assets on the balance sheet. MSA Prices are commercial real estate prices at a local MSA area in the current year scaled by the real estate price in 2010 . Regarding accounting variables, an average firm has book value assets of $\$ 1.21$ billion, R\&D as 8 percent of assets, leverage as 21 percent of assets, ROA as -0.01, Tobin's Q as 2.26, institutional ownership as 34 percent, herfindahl index as 15 percent, and 20 years old since its IPO date.

\footnotetext{
${ }^{17}$ Sometimes, one entrepreneurial venture is associated with more than one 2 -digit SIC code. In this case, I assign one to the diversification measure if the 2-digit SIC code of the venture is the same with the parent firm, and zero other wise. Then I take average of the diversification measure for each venture to obtain a final measure of diversification.
} 
I measure innovation of a firm using both innovation output proxied by patents and citations per patent, and innovation input measured by acquisitions, CVC investment, and R\&D. On average, a firm in my sample files 8.4 patents (and eventually granted) each year, and each patent receives 5.8 citations. On average, each firm has 0.4 acquisitions each year. In other words, an average firm has one acquisition every 2 years. I also examine acquisitions where targets file at least one patent prior to acquisition. An average firm in my sample has 0.04 number of acquisition deals each year where targets file some patents before acquisition. In addition to the number of deals, I also examine the volume of deals measured by dollar amount. On average, the dollar amount spent on acquisitions is $4 \%$ of the book value of total assets, and dollar amount spent on innovative acquisitions is $1 \%$ of the book value of total assets. Regarding CVC investment, since only 127 firms in my sample has CVC programs, I report summary statistics for the subsample of firms with CVC programs. For these firms, they have 1.1 CVC investment each year, and the volume of their CVC investment is 10 basis point of the total book value of assets. Not all the firms report their R\&D spending, so R\&D investment for some firms is missing in COMPUSTAT. I replace these missing R\&D investment by 0 . One common characteristic of these innovation variables is that they are all highly skewed. The medians of these variables are 0 while the means are positive. To mitigate the econometric problems associated with a skewed dependent variable, I take natural logarithm of one plus the variable in the regression analysis.

Panel B reports the geographic distribution of sample firms. My sample firms are distributed among 40 states. I observe that $19.9 \%$ of sample firms are headquartered in California, followed by Massachusetts (7.16\%), New York (6.92\%), and New Jersey (5.88\%).

\section{Research design}

\subsection{Baseline specification}

I first explore the effect of real estate value changes on innovation outputs in a naïve OLS panel regression framework. Specifically, I estimate the following reduced form model:

$$
\operatorname{Ln}\left(\text { Innov }_{i, t+1 \sim t+5}^{l}\right)=\beta_{0}+\beta_{1} \text { ReValue }_{i t}+\gamma P_{t}^{l}+\text { Controls }_{i t}+\alpha_{i}+\delta_{t}+\varepsilon_{i t},
$$

where Innov $_{i, t+1 \sim t+5}^{l}$ refers to the innovation output (measured by patent counts and patent citations) scaled by beginning-of-year assets of firm $i$ in the following five years. ReValue $i t$ is the ratio of the market value of real estate holdings of firm $i$ in year $t$ to beginning-of-year assets, 
and $P_{t}^{l}$ controls for the level of real estate prices in location 1 (MSA) in year $t$, which is supposed to account for the overall real estate cycle effect on innovation for firms that do not own real estate. $\alpha_{i}$ is firm fixed effect, which controls for the effect of unobserved firm characteristics on innovation. $\delta_{t}$ represents year fixed effect, which control for time trend in innovation. I cluster the standard errors at the state/MSA $\times$ year level.

Controls $_{i t}$ include a set of firm-specific control variables following the innovation literature, including cash flow, leverage, profitability, investment opportunities, market competition, institutional ownership, age, and tangibility of assets. Since I have scaled innovation and real estate value by assets, I do not control for it again in the regression.

The coefficient $\beta_{1}$ measures how sensitive innovation output is to real estate value. In particular, it measures the percentage increase in innovation when real estate value (scaled by beginning-of-year assets) increases by one unit.

\subsection{Identification}

The market value of real estate holdings is likely to be endogenous in the proposed setting in two ways. First, real estate prices might be correlated with unobservable investment opportunities, and such correlation might drive innovation outputs. Second, real estate holding decisions are endogenous to the firm, and hence are jointly determined by firms' characteristics and investment opportunities, which might also affect innovation.

How would these endogeneity issues bias my results? For the first issue, if the demand of a firm for innovation increases, then this firm might have a higher demand for labor and other local activities. And if this firm is a large land-holding one, it might trigger increase in local real estate prices. If this is true, then I might overestimate the sensitivity of innovation to real estate prices. For the second issue, I might also overestimate innovation to real estate prices sensitivity, since firms that are more likely to own real estate are also more sensitive to local demand shocks.

To address the first concern, I instrument local real estate price changes by the interaction of local land supply elasticity with a proxy for national demand of real estate. This methodology improves upon Mian and Sufi (2011) and Chaney, Sraer and Thesmar (2012) by using occupancy rate as a proxy for commercial real estate demand. If a building has 10 units, and 8 of are rented, then the occupancy rate is $80 \%$. For commercial real estate, occupancy rate is the source of demand from tenants who rent the space that leads to returns and price increases for the 
space owned by investors (e.g. Brucegeman and Fisher (2010)). A higher occupancy rate indicates a higher demand for commercial real estate, and it would affect the price changes in an MSA area through the local land supply elasticity.

Saiz (2010) develops a measure for price elasticities of the housing stock at the MSA level, by using GIS techniques to measure geographical constraints on local land supply, as well as factors that account for endogenous restrictions on land use through zoning regulations. This identification strategy partially allows me to capture the effect of the real estate prices on access to credit for each firm, by taking advantage of the fact the high-elasticity area experience higher price variations compared to low-elasticity when they hit by the same real estate demand shock from the national level. It is because if the local supply of land were elastic, the increased demand would lead to more housing construction rather than higher land prices. I estimate real estate price percentage changes ReRet $_{t}$ for MSA 1 in year $\mathrm{t}$ using the following regression framework:

$$
\operatorname{ReRet}_{t}^{l}=\gamma_{0}+\gamma_{1} \cdot \frac{1}{\text { Elasticity }^{l}} \times \text { OccupancyRate }_{t}+\alpha^{l}+\delta_{t}+u_{t}^{l},
$$

where Elasticity ${ }^{1}$ is the elasticity on land supply at the MSA area l, OccupancyRate is $_{t}$ the nationwide occupancy rate of commercial real estate, $\alpha^{1}$ is an MSA fixed effect, and $\delta_{t}$ is year fixed effect. Then I use $\widehat{P}_{t}^{1}$ predicted from equation (2) to compute real estate value in regression (1), and as control for local prices. Table 2 reports regression results of this first-stage regression. As one can see from the table, elasticity and interest rate have significant effects on MSA prices. In addition, I show the evolution of commercial real estate prices from 1990 to 2010 for MSAs with high and low local land supply elasticity in Figure 1. The figure shows that the boom of commercial real estate market was more dramatic for places with low land supply elasticity. This is consistent with the idea that expansion in housing supply in places with high local land supply elasticity put an upper bound on real estate prices.

To address the second concern, I follow Chaney, Sraer, and Thesmar (2012) by controlling for the determinants in the real estate ownership decisions in the estimation of innovation sensitivity to real estate value. Specifically, I interact initial characteristics of firm i which proxy for the likelihood for the firm to own real estate, $\mathrm{X}_{\mathrm{i}}$, with real estate prices $\mathrm{P}_{\mathrm{t}}^{\mathrm{l}}$, and control for them in the regression as fixed effects. The idea is that firms that are more likely to 
own real estate should be more sensitive to real estate prices. The $\mathrm{X}_{\mathrm{i}}$ is a vector of five quintiles of Age, Assets, Return on Assets, two-digit industry dummies and state dummies.

Controlling for the potential bias caused by two types of endogeneity, the new baseline specification becomes:

$\operatorname{Ln}\left(\right.$ Innov $\left._{i, t+1 \sim t+5}^{l}\right)=\beta_{0}+\beta_{1}$ ReValue $_{i t}+\gamma \hat{P}_{t}^{l}+\sum_{k} \mathcal{K}_{k} X_{k}^{i} \times \hat{P}_{t}^{l}+$ Controls $_{i t}+\alpha_{i}+\delta_{t}+$ $\varepsilon_{i t}$,

where REValue is real estate value computed using local prices proxied by equation (2), $\widehat{\mathrm{P}}$ is predicted local prices using equation (2), $\mathrm{X}$ is control of initial characteristics of the firm.

\section{Collateral shocks and patenting activities}

\subsection{Patents and citations per patent}

Table 3 reports estimates of various specifications of equations (1) and (3). Panel A1 reports the regressions results using $L n P a t_{t+1 \sim t+5}$ as the dependent variable. Column (1) - (3) reports the OLS regression results, and column (4) - (6) presents IV estimates. Column (1) starts with the simplest estimation of equation (1) without any additional controls. Firms owning real estate increase their patent filings more than firms not owning real estate when real estate prices increase. In column (2), I add the local real estate prices and initial controls interacted with real estate prices that account for the observed heterogeneity in ownership decisions and its potential impact on the sensitivity of innovation to real estate prices. In column (3), I add standard controls for innovation following innovation literature in addition to real estate prices and initial controls. The coefficient estimates on $R E$ Value remain positive and significant at one percent confidence level across all three columns. In column (4) - (6), I also gradually add in controls as in column (1) - (3) with IV regressions. The coefficient estimates on RE Value stay positive and significant at one percent confidence level across all three columns. and the magnitude gets larger compared to the corresponding regressions in Panel A. The baseline coefficient in column (6) is 0.767 . The economic magnitude is sizable. A one-standard deviation increase in real estate value---which brings the real estate value from sample mean (the 65 percentile) to the 86 percentile---leads to a 25 percent increase in patents filed and granted in the subsequent five years, which is 14 percent 
of standard deviation of patent counts. ${ }^{18}$ This change brings the patent filed and granted in the subsequent five years from 76 percentile to 79 percentile.

With regard to control variables in Panel A1, firms that are larger, and those with lower leverage, higher Tobin's Q, higher institutional ownership, more tangible assets, and younger file more patents as a response to positive collateral shocks. Firms located in MSA areas with higher prices are also likely to be more innovative, which is likely to be due to the fact that higher MSA area prices proxy for higher investment opportunities. Firms with larger sales have less innovation, and this is because I have scaled the dependent variable innovation by book value of assets. According to prior studies, small firms normally account for a disproportionate size of innovation since large firms are inefficient at mixing routine tasks with innovation (Holmstrom (1989)). These results are consistent with intuition and existing literature.

Panel A2 presents IV estimates using patent filings year by year as the dependent variable. The coefficient estimates on ReValue is positive and significant for all 5 years. In Panels B1 and B2, I replicate the estimation performed in Panels A1 and A2 using citations per patent instead of patents as the dependent variable, and find qualitatively similar results. The economic magnitude is also sizable. A one-standard deviation increase in real estate value---which brings the real estate value from sample mean (the 65 percentile) to the 86 percentile---leads to a 28 percent increase in average citations received by a patent filed and granted in the subsequent five years, which is 13 percent of standard deviation of citations per patent. ${ }^{19}$ This change brings the citations received by each patent filed and granted in the subsequent five years from 80 percentile to 82 percentile. The results suggest that firms increase both their innovation quantity and innovation quality as a response to collateral shocks.

\subsection{Originality and generality}

In addition to patent quantity and quality, I also explore the effect of collateral shocks on patent novelty and riskiness. Patents that cite a wider array of technology classes of patents are viewed as having greater originality. I thus define Originality as one minus the Herfindahl index

\footnotetext{
${ }^{18}$ Increasing ReValue by one standard deviation $(0.324)$ increases LnPat $t_{t+1 \sim t+5}$ by $0.767 \times 0.324=0.248$, which represents $0.248 \times 0.129$ (mean) $=0.032$ number of citations per patent, and it is 14 percent of the standard deviation (0.229) of citations per patent.

${ }^{19}$ Increasing ReValue by one standard deviation (0.324) increases by LnCitePat $t_{t+1 \sim++5} 0.886 \times 0.324=0.287$, which represents $0.287 \times 0.156$ (mean) $=0.045$ number of patents, and it is 13 percent of the standard deviation $(0.333)$ of patents.
} 
of the three-digit technology class distribution of all the patents that the current patent cites. A higher patent originality score means that the patent is drawing on a more diverse array of existing knowledge. In a similar spirit, patents that are being cited by a wider array of technology classes of patents are viewed as having greater generality. Specifically, I define Generality as one minus the Herfindahl index of the three-digit technology class distribution of all the patents that cite the current patent. The greater the variable, the broader industries the current patent affects subsequent innovations are. Both Originality and Generality can be used to measure the riskiness in a firm's pursuit of $R \& D$ and how fundamental the research is. The rationale is that the more fundamental and radical the research is, the more likely it is going to draw from a wide range of industries. It is very rare that fundamental and radical innovation comes from scientists work in a narrow area alone.

Table 4 reports the $2^{\text {nd }}$-stage estimates from the 2SLS regressions for patent Generality and Originality. Panel A uses Originality as dependent variable. The coefficient estimates of ReValue are positive and significant starting from the second year after collateral shocks to fifth year after collateral shocks. They suggest that higher collateral value leads to higher patent originality. It implies that the booming real estate market encourages a firm to take more radical innovation, and pursues in risk-taking strategy. Panel B uses Generality as dependent variable. The coefficient estimates of ReValue are positive but not significantly different from zero. It suggests that even though firms file patents that are more fundamental and cite a wider range of industries, the citations of these patents are not significantly spread over a larger number of technological fields.

\subsection{Industry distribution}

In addition to measures on the characteristics of individual patents, I examine the structure of patent portfolio. In particular, I focus on the industry distribution of patents, by examining whether collateral value increase leads to patents filed more in industries different from the parent firm. If firms are prone to a more risk-taking strategy of innovation, they are very likely to expand into industries that are different from parent firm.

Table 5 reports the effect of collateral shocks on industry distribution of patents. The dependent variable is the percentage of patents that are in a different 2-digit SIC industry from the incumbent firm. Consistent with the conjecture, the percentage of patents in industries 
different from the parent firm increases in the subsequent five years after a positive collateral shock.

\section{Collateral shocks and innovative investment}

After establishing a first-order impact from collateral shocks on innovation output, I investigate how collateral shocks affect innovation budgets through three channels. The first one is in-house innovative investment --- internal $\mathrm{R} \& \mathrm{D}$, the second one is external innovation --acquisitions of innovative targets, and the third one is a "hybrid" model --- CVC investment that combines laboratory research and venture capital investment.

Prior studies have shown that each channel contributes to innovation output respectively. R\&D conducted in a corporate lab is probably the most widely known form of innovation. The literature on patent race and the endogenous growth has largely used R\&D as a simplified representation of innovative activities in a firm. Recently more studies have argued that acquisitions promote innovation of the parent firm when there are synergies obtained from combining innovation capabilities of the acquirers and the targets (e.g. Bena and Li (2014), Rhodes-Kprof and Robinson (2008)). Finally, a firm may also move innovation outside its boundaries through CVC programs. ${ }^{20}$ Corporations operate CVC programs as subsidiaries, and they act as venture capitalists through CVC programs by investing in entrepreneurial start-ups. Prior studies suggest that CVC programs are associated with higher innovation productivity and firm value (Dushitsky and Lenox $(2005,2006)$ ). The three channels, accompanied with exogenous variation in collateral value, provide an excellent testing laboratory for how access to finance affects firms' capital allocation.

There has been a lot of debate on the bright side and the dark side of diversification (e.g. Hadlock, Ryngaert, and Thomas (2001), Lamont and Polk (2002), Scharfstein and Stein (2000)). In particular, Stein (1997) argues that the principal benefit of diversification is that the headquarters (HQ) can better channel resources within the firm from divisions with poor investment opportunities to divisions with more promising prospects. However, he also points out that internal capital market might also fail to redeploy capital to sectors with better investment opportunities because of information advantage enjoyed by subdivisions and the

\footnotetext{
${ }^{20}$ Strategic alliance is also an important way for a firm to conduct its innovative activities outside of the boundaries (Robinson (2008)). I do study it in this paper since it is empirically difficult for me to observe a firm's resource allocation on strategic alliance.
} 
costs associated with evaluating and monitoring multiply projects. Finally, he shows that a credit-constrained firm should focus its resources and take related projects.

While Stein (1997) fixes the cost of external finance, and derives the optimal size and scope of an internal capital market, I examine the comparative statics of the effects of access to finance on capital allocation through the internal capital market. A large literature has discussed the effect of internal capital market on resource allocation (e.g. Berger and Ofek (1995), Stein (2003)), and in particular whether internal capital market provides an important force countervailing financial market dislocation (Matvos and Seru (2014), Gertner, Scharfstein, and Stein (1994)). In this paper, instead of focusing on the ex-post effect of internal markets on resource allocation, I focus on how access to capital shapes the distribution of resource allocation ex ante.

\subsection{Size effect}

In this section, instead of examining the relation between innovative investment and outputs that have already been explored a lot by prior studies, I take a step back and investigate how access to capital affects a firm's resource allocation through these three channels. To mitigate the concern that some acquisitions may not be made to enhance the acquirers' innovation, I filter the acquisition deals by only including ones where targets generate at least one patent prior to acquisition. The underlying assumption is that these types of deals are made to promote parent firm innovation. One caveat is that innovative targets may not necessarily produce patents prior to acquisition, and they might just be in process of innovation and would file patents after being acquired. In addition, acquisitions that intend to increase the innovation of the acquirer may not necessarily involve acquiring targets with patents, and the human capital acquired from the targets could also be valuable to the acquirer. In the end there is a tradeoff between using all acquisition deals with noise or restricting the acquisitions deals to a small group, which might also induce some noise by missing some relevant deals.

Table 4 reports the effects of collateral shocks on these three channels separately. It appears that a firm increases its investment on all the three channels as a response to positive collateral shocks, and the increase is significant at one percent level. A firm does not only increase the dollar amount spend on CVC investment and acquisitions, but also take more CVC projects and acquisition deals. As we observe an increase in patenting outcome starting from the 
first year after collateral shock to the fifth year, an increase in the investment in three channels suggest that the patenting outcomes in the first year is likely to be associated with an increase in acquisitions which may provide some patents to the acquirer immediately. An example is Google's purchase of Motorola in 2011, and Google obtained the patents of Motorola. Aside from a direct transfer of patents, it generally takes a longer time for innovation to reach the patenting stage. The synergy effects of combining the innovation capabilities of the acquirer and the target, the in-house $\mathrm{R} \& \mathrm{D}$, and the corporate venture capital investment may take a longer time than one year to generate patents and are associated with patent increase in later years.

Furthermore, the investment through three channels increases by different magnitudes. The percentage increase in innovative acquisitions is the most, the percentage increase in CVC investment is the second most, and the percentage increase in internal R\&D is the least. The results can be explained both by information asymmetry and adjustment cost.

The information asymmetry problem is probably most severe on acquisitions out of the three channels. It is generally difficult for an outsider to know the true state of a firm, and the nature of innovation intensifies the problem. A target could not reduce the information asymmetry problem by revealing much information to acquirer, since innovation loses value if it could be imitated after disclosure (e.g. Bhattacharya and Ritter (1983)). The information asymmetry gets slightly reduced in a CVC investment, since the incumbent firm could monitor the entrepreneurial ventures. However, given ventures conduct innovative research outside the boundaries of the incumbent firms, there is still a certain degree of information asymmetry. Out of the three channels, in-house $R \& D$ investment suffers the least from information asymmetries. Therefore, as collateral pledging alleviates underinvestment, a firm has incentives to accelerate investment in the project that suffers the most from agency problems. Acquisitions, which were likely greatly impeded when the firm is credit constrained, gets the highest percentage increase when the credit constraint is relaxed.

The adjustment costs are also different for three types of investment. R\&D probably has the highest adjustment cost (e.g. Lach and Schankermann (1988)). As pointed out by Hall and Lerner (2010), "fifty per cent or more of R\&D spending is the wages and salaries of highly educated scientists and engineers" and "part of the resource base of the firm itself disappears when such workers leave or are fired". So firms tend to smooth R\&D spending over time, in order to avoid the costs stemming from laying off knowledgeable workers. For a CVC 
investment, it typically takes several rounds, and it is also costly for a firm to suddenly withdraw. Acquisitions tend to have the lowest adjustment costs out of the three channels, and CEOs withdraw acquisitions sometimes. As a result, when there is a variation in capital access, a firm could adjust acquisition in a faster mode than the other two types of investment.

\subsection{Acquisitions}

The evidence so far shows that collateral shocks have a positive effect on innovative investment. For acquisitions and corporate venture investment, both the dollar volume and number of deals increase as a response to improved credit access. In this section, I explore whether the characteristics of acquisition deals are affected by the collateral shocks. Table 7 reports the effect of collateral shocks on the characteristics of acquisitions. The regressions are based on deal-year level. First, I find that acquisitions associated with an increase in real estate value are more likely to be cash-based. This lends further credence to the collateral mechanism. If real estate value increase results in higher borrowing capacity and firms pledge real estate to issue secured debt, then firms have more cash available and their acquisitions are more likely to be financed by cash.

I also examine the characteristics of targets in Table 7. It seems that targets acquired when the firm experiences an increase in the collateral value are more likely to be industries different from the SIC 2-digit industry of the parent firm. This result is consistent with evidence in Table 5 that patents filed following improved access to credit are more likely to spread in SIC 2-digit industries different from the parent firm. In addition, these targets on average have higher

patents and citations per patent prior to the acquisition. It implies that firms are more likely to acquire those innovative targets following relaxed financial constraints.

\subsection{Corporate venture capital investment}

In addition to the characteristics of acquisitions, I examine the characteristics of corporate venture capital investment in Table 8 . Corporate venture capital investment is equity investment in startups by incumbent firms. I investigate the characteristics of the startups invested by the incumbent firms, when there is an increase in the real estate value for incumbent firms. I find that these startups invested by incumbent firms when there is higher collateral value are more likely to be in different 2-digit SIC industries from the incumbent firms. This is consistent with 
the findings on the industry distribution of patent filings and targets. Overall, the results imply that firms are taking riskier approach in the pursuit of innovation, by expanding into industries with different technologies.

In addition to industry distribution, I also investigate when the firm enters into the investment for entrepreneurial firms, and the age of the entrepreneurial firms when the firm invests. When there is an increase in the collateral value of the firm, the firm seems to enter into the investment in startups at earlier rounds, and invest in those younger startups. This can be interpreted as that the firms are taking a more risky approach in the pursuit of innovation when there is a relaxation of financial constraint following collateral value increase. With higher access to credit, they pursue more radical, path-breaking innovation through investment in younger startups at their earlier stages.

Finally, I examine the exit of these startups as an ex-post measure for their quality. Interestingly, these startups have a significant chance to be acquired in the end, while the chance of IPO or bankruptcy is insignificant for them. It indicates that these startups are of good innovation potential. The fact they get acquired in the end is consistent with the findings in the literature that firms use corporate venture capital programs to identify potential targets (Benson and Ziedonis (2010)).

Taken together, the evidence in this section suggests that following improved access to credit, firms shift their trajectory of innovation from incremental and sustaining innovation to more experimental and path-breaking innovation. They acquire more innovative targets, and also invest in younger, risky startups with higher innovation potential.

\section{Cross-sectional variations}

In the previous sections, I provide evidence that collateral shocks positively affected innovation. One may expect that the magnitude of this effect could differ across different firms. In this section, I examine the innovation implications of collateral shocks across different sections. I first explore the cross-sectional variation in secured debt in section 7.1. Next, in Section 7.2, I explore the cross-sectional heterogeneity in innovation difficulty. Then, in Section 7.3, I explore debt the cross-sectional differences in financial constraints. In Section 7.4, I examine the cross-sectional differences in cash holdings. Finally, in Section 7.5, I examine the cross-sectional variations in local real estate volatility. 


\subsection{Secured Debt}

An increase in real estate value has two effects on a firm. First, an appreciation of real estate value leads to an increase in the asset liquidation value of a firm. It boosts up the debt capacity, since a debt contract allows a lender to seize firm assets in the case of bankruptcy. A firm may issue more unsecured debt against the increase in the asset value induced by real estate appreciation. Second, real estate could be used as collateral for a firm to issue secured debt. As pointed out by Stulz and Johnson (1985), by securing new lenders with collateral, a firm would be able to mitigate "debt overhang” problem documented in Myers (1977).

Underinvestment problem could be particularly severe in innovative firms, since innovation is associated with acute agency problems due to the nature of it. As a result, an innovative firm may not be able to issue unsecured debt, and the option of issuing secured debt would relax its financial constraints. To test whether a firm uses real estate as collateral, I rely on two tests. First, I examine the effect of real estate shocks on the level of outstanding secured debt. If a firm does use real estate as collateral, we should observe an increase in secured debt issuance. $^{21}$ Second, I examine whether the effects of collateral shocks on innovation are more pronounced in groups of firms that are more dependent on secured debt borrowing. If collateral pledging is important for financing innovation, we shall observe a higher increase in innovation as a response to real estate appreciate for firms with higher levels of secured debt. ${ }^{22}$

Table A1 shows the response of the capital structure to real estate shocks. As we can see in column (3) and column (4), there is an increase in the level of long-term secured debt, and a decrease in the level of long-term unsecured debt. The results suggest that the firm is using real estate as collateral to issue new secured debt. Aside from secured and unsecured debt, Table A1 also shows that, following real estate value appreciation there is an increase in net long-term debt issuance and net short-term debt issuance. This is probably because that real estate loans are of longer maturity compared to other loans. Finally, Table A1 also shows that there is no increase in equity issuance as a response to real estate value appreciation.

\footnotetext{
${ }^{21}$ Since COMPUSTAT only reports the level of outstanding long-term secured debt, I have to rely on that. Ideally, it would be better that I can examine the issuance of secured debt.

${ }^{22}$ It is possible that a firm does not directly use real estate collateral to finance innovation, but use it to finance capital expenditure. Even so, some of the previously occupied resources are released now and allow a firm to increase its input in innovation. I do not distinguish these two cases in this study, since either case is consistent with the idea that an increase in access to capital allows more innovative investment of a firm.
} 
Panel A in Table 9 presents cross-sectional variations of the IV estimates using secured debt reliance to split samples. Secured debt category assignments use the ratio of long-term secured debt outstanding to total long-term debt outstanding in the current year, where firms above the median of the ratio are regarded as those with more collateral pledging and firms below the median are assigned as less collateral pledging firms. The results suggest that firms that issue more secured debt have a higher sensitivity of patents and citations per patent to real estate shocks. It is consistent with the hypothesis collateral pledging mitigates underinvestment problems for innovative firms.

\subsection{Innovation difficulty}

Firms in industries with higher innovation difficulty might require more resources to innovate, and hence they might face stricter financial constraints. In this section, I examine whether the effect of collateral shocks on innovation is driven by firms in industries which are more demanding innovation. As in Hall, Jaffe, and Trajtenberg (2005), more demanding industries include pharmaceutical, medical instrumentation, chemicals, computers, communications, and electrical industries, and the rest are classified as less demanding industries, which include software programming, internet applications, and other low-tech industries. I group firms in the industries that are more difficult to achieve innovation and that are less difficult to achieve innovation following standard methods in the literature (e.g. Tian and Wang (2014), Mao, Tian, and Yu (2013)).

Panel $\mathrm{B}$ in Table 9 reports the IV estimation results for two subsamples of firms. I observe that collateral shocks significantly affect patents and citations in industries that are more difficult to innovate, and collateral shocks only affect patent counts in industries where innovation is less difficult to achieve. In addition, the magnitude of the effects is smaller in less demanding industries.

\subsection{Ex-ante financial constraints}

To provide more direct evidence on whether financial constraints are the underlying force for the changes in the firm's innovation output, I examine in this subsection how the change in innovation output upon collateral shocks differs among firms being subject to different degrees of financial constraints. If firms indeed pledge the increased collateral value for more borrowing, 
I expect that firms with higher financial constraints would benefit more from collateral value increases and get hurt more from collateral value drops.

To test the hypothesis, I divide firms into financially constrained groups and financially unconstrained groups according and repeat the regressions in Eq. (3). I use three measures for financial constraint, including firm size, dividend payout policy, and bond ratings. Dividend payout ratio is computed as dividends on common stocks divided by income before extraordinary items adjusted for common stock equivalents. I put a firm in the constrained category in it does not pay dividend are regarded as constrained firms, and firms paying dividend are unconstrained firms. A firm is regarded as financially constrained if the size of its book assets falls in the bottom tercile of the whole distribution, and unconstrained if the size of its book assets falls in the top tercile of the whole distribution. Firms without bond rating (splticrm) are categorized as financially constrained, and financially unconstrained firms are those whose bonds are rated.

Panel $\mathrm{C} 1$ and Panel $\mathrm{C} 2$ in Table 9 report subsample results for firms facing different financial constraints. The dependent variables in Panel $\mathrm{C} 1$ are patents per firm as a measure of the quantity of innovation, and citations per patent as a measure of the quality of innovation. Across all the measures of financial constraint, I consistently find that the estimated coefficients of ReValue are significantly larger in the constrained firms than unconstrained firms. In addition, I also run a t-test of equality of the ReValue coefficients between the constrained sample and the unconstrained sample, and I find that the difference between the coefficients is significant at the 1 percent level for all three measures of credit constraints.

One issue that is worth noticing is that though patent count and citations appear to be more sensitive to collateral shocks in the subsample where firms face higher financial constraints, the results are not entirely driven by financially constrained firms. Firms that face relatively less tight financial constraint also experience increase in innovation as a response to collateral shocks.

\subsection{Cash holdings}

In this section, I examine the effect of collateral shocks on cash holdings of a firm. If firms have enough internal fund for financing innovation, then innovation in a firm should not be sensitive to collateral shocks. In other words, if firms are generally financially constrained, we 
shall expect to the effect of collateral shocks on innovation more pronounced for firms with low internal fund. I use annual cash holdings to proxy for a firm's internal fund.

Panel $\mathrm{D}$ in Table 9 reports the $2^{\text {nd }}$. stage regression results of collateral values on innovation for low cash holding and high cash holding firms. Consistent with the conjecture, real estate price variables have a larger impact on the subgroup of firms with lower cash holdings.

\subsection{Historical real estate price volatility}

Finally, I look at local real estate price volatility. If firms are located in an MSA with a history of high real estate price fluctuations, then the collateral value of their real estate is worth less to banks. In other words, banks would lend less against the same level of real estate in MSA areas with high historical local real estate price fluctuations. I directly test this conjecture in this subsection, as a further verification of the identification strategy.

I measure local real estate price volatility by the standard deviation of the commercial real estate price index in the previous five years for a given MSA area. Then I divide the firms into two groups according to their local real estate price volatility. If their local real estate price volatility is higher than the median of local real estate price volatility for all firms in a given year, then I assign the firm into the group with high real estate price volatility, and vice versa. Consistent with the conjecture, Panel E in Table 9 shows that the effect of collateral shocks on innovation is more pronounced for the subset of firms located in MSAs with low real estate price volatility.

Overall, the cross-sectional tests further lend credence to the causal inferences of the positive effect of collateral value on corporate innovation. While it is possible that some omitted variables drive the documented results, it is difficult to conceive of an omitted variable that biases the results equally along all cross-sections. The differential effects of collateral shocks on innovation along these dimensions alleviate the identification concern to some extent, as my results are unlikely to be entirely driven by an omitted variable that decides real estate prices and innovation simultaneously. Instead, it appears to suggest that a treatment effect is at least partially at play. 


\section{Robustness checks}

\subsection{Exclusion restrictions}

In my identification strategy, I use local land supply elasticity to instrument for local commercial real estate price growth. Local land supply elasticity is a geography-based measure developed by Saiz (2010). Geographical constraints (e.g. steep-sloped terrain) affect land supply elasticity both directly and indirectly: (1) geographical constraints directly limit the amount of land available for real estate developers; (2) geographical constraints indirectly impose higher incentives for antigrowth regulations via increased land values. Either way, local land supply elasticity puts an upper bound on the growth of real estate prices in a local area by restricting the expansion of real estate property volumes.

The identification assumption here is that local land supply elasticity is exogenous to local demand shocks. If the assumption is true, price growth instrumented by local land supply elasticity is orthogonal to factors that might drive innovation growth in an area. By this argument, the difference in innovation growth in two MSA areas is purely driven by different real estate price growth instead of some differential economic trends. Therefore, the innovation difference for firms across different MSA areas is likely to be driven by differential increases in the collateral value. A potential drawback of this argument is that MSA areas with different local land supply elasticity might be subject to different demand shocks. If an inelastic MSA area is more likely to be subject to higher investment opportunity shocks, then the growth in innovation and real estate prices could be naturally correlated. As a result, what I am capturing could be just spurious correlations between innovation and real estate prices.

Mian and Sufi (2011) and Cvijanovic (2014) have excellent discussions confirming the validity of the exclusion restrictions. They invesigate the economic trends in elastic and inelastic MSA areas (Mian and Sufi (2011) focus on 2002-2006, and Cvijanovic (2014) focuses on 19932006). More precisely, they examine local land supply elasticity and MSA-level economic indicators including: real GDP growth, per capita GDP growth, disposable personal income growth, per capital income growth, and wage growth. In addition, Mian and Sufi (2011) examine the shocks to these economic indicators. The obtained evidence of them suggests that elastic and inelastic metro areas were not experiencing different economic trends that may have driven corporate or individual borrowing in their sample periods. 


\subsection{Other robustness checks}

Table A2 provides various robustness checks of the baseline estimation of equation of equation (3). I use both patent and citation per patent as the dependent variables, measured during the 5-year period post collateral shocks. A higher number of patents indicates higher quantity of innovation output, and a higher number of citations per patent indicates higher quality of innovation output.

Panel A reproduces the estimations on two different subsamples of firms: firms with their headquarters in California or Massachusetts in column (2) and (4), firms with their headquarters outside California or Massachusetts in column (1) and (3). This panel addresses the potential concern about reverse causality. Firms that are located in California or Massachusetts are most likely to be subject to reverse causality problem, since there are many innovative firms in the area and it is likely that their innovation drives real estate prices in the area. The coefficient estimates is positive and significant at 1 percent level in both subsamples. Interestingly, the magnitude of the coefficient appears to be larger in the subsample of firms the headquarters of which are not in California or Massachusetts, and it is not statistically different from, the coefficient estimated on the entire sample ( 0.820 compared to 0.767 , and 0.883 compared to 0.886). Neither the significance not the magnitude of the coefficient of interest seems to come from the subsample of firms that are headquartered at California of Massachusetts.

Panel B estimates equation (3) for two subsamples of firms: small firms in large MSAs in column (1) and (3), large firms in small MSAs in column (2) and (4). This specification also addresses the concern of reverse causality. It is likely that large firm's innovation affect real estate prices in the local area especially when it is not a large MSA. Small firms in large MSAs would suffer less from this type of reverse causality. For small firms, I consider firms in the lower three quartiles of size, and in the largest 20 MSAs. For large firms, I consider only firms in top quartile of size, and in the MSAs smaller than the largest 20 MSAs. The estimated coefficient remains significant at 1 percent level for patents and citations for small firms in large cities. While the magnitude of patent measure is smaller than the full sample, the magnitude of citation measure is higher than the full sample. It seems unlikely that large firms in small MSAs drive the results.

Panel C reproduces the estimation on two different subsample periods: before 2000 in column (1) and (3), and after 2001 in column (2) and (4). A potential concern with pooled 
regressions as the ones presented in Table 3 is that they ignore the time-variation of sensitivities of innovation to collateral shocks. So I estimate equation (3) separately on two different sub periods, 1993-2000, and 2001 to 2009. The estimated coefficients are positive and significant at 1 percent level for both sub periods, with the magnitude in 2001-2009 higher than in 1993-2000. It might be related to the higher volatility of real estate prices in the later period. Overall, neither the significance nor the magnitude of full sample results seems to come from a particular time period.

Panel D estimates equation (3) replacing ReValue by ReOwn. ReOwn is the interaction of a dummy variable that equals to 1 when a firm owns real estate initially and commercial real estate price index at the MSA level. The tests in this panel are designed to examine whether the empirical distribution of real estate value affects results. The coefficient estimates are positive and significant, indicating that my results are not driven by large real estate holding firms. The magnitude of coefficients implied by the dummy regressions is also very similar to specification that uses the value of real estate in Table 3. The results in this panel lend further support to the validity of the main empirical framework.

\section{Conclusion}

In this paper, I aim to tackle the question that how external financing cost affects the way a corporation innovates. Using plausibly exogenous variation in the real estate collateral value as shocks to credit constraints, I find that the relaxation of credit constraints spurs a firm's patenting outcomes through three channels: R\&D, acquisitions of innovative targets, and CVC investment. Among these three channels, acquisitions enjoy the largest increase, CVC investment experiences the second largest increase, and R\&D has the least increase. I further show that, following improved credit access firms begin to take a riskier approach in the pursuit of innovation, and invest more in radical innovation. Finally, subsample analysis shows that the increases in innovation is more pronounced for firms that are credit constrained, issue more secured debt, in industries where innovation is more difficult to achieve, or in MSA areas with lower historical real estate price volatility.

My paper contributes to the literature in several ways. First, this paper is the first one that combines the three innovation channels, and examines how access to finance affects resource allocations through these three channels. Second, this paper examines the forms of innovation 
(incremental vs. radical) as a response to collateral shocks, in addition to the level of innovation. Innovation provides a nice testing avenue since the agency problems are particularly severe, and the data on patents and the three channels allows me to explore in a granular level the industry diversification of the investment. Third, this paper contributes to the emerging literature on credit constraints and corporate innovation. In particular, I use firm-level real estate collateral to investigate the causal impact of credit access on innovation through the micro channel.

While I show a positive effect of credit access on firm innovation, one needs to be cautious in interpreting the results. It is possible that collateral pledging mitigates underinvestment problems. However, I cannot rule out the possibility that managers use collateral to take extra risk. It is extremely difficult to empirically test whether a firm over invests due to the lack of a benchmark- a firm's optimal level of investment mix.

To take one step further toward a normative conclusion, I rely on prior literature. As shown by Hall, Jaffe, and Trajenberg (2005), patent citations are significantly positively related to a firm's market value, measured by its Tobin's Q. More precisely, they find that an extra citation per patent boosts a firm's market value by 3\%. As this paper shows higher citations per patent, it is consistent with the hypothesis that a firm's market value increases following real estate value appreciate. However, we still need to remain cautious in interpreting the results in this paper. 


\section{References}

Acharya,V., Baghai, R., and K. Subramanian, 2014. Wrongful discharge laws and innovation. Review of Financial Studies 27, 301-346.

Acharya, V. and Z. Xu, 2013. Financial dependence and innovation: the case of public versus private firms. Unpublished Working Paper.

Akcigit, U., and W. Kerr, 2012. Growth through heterogeneous innovations. NBER Working Paper No. 16443.

Adelino, M. A. Schoar, and F. Severino, 2014. House prices, collateral and self-employment. Journal of Financial Economics, forthcoming.

Aghion, P., J. Van Reenen, and L. Zingales, 2013. Innovation and institutional ownership. American Economic Review 103: 277-304.

Aghion, P., N. Bloom, R. Blundell, R. Griffith, and P. Howitt, 2005. Competition and innovation: An inverted U relationship. Quarterly Journal of Economics 120: 701-728.

Aghion, P. and J. Tirole, 1994. On the management of innovation. Quarterly Journal of Economics 109, 1185-1209.

Almeida, H. and M. Campello, 2007. Financial constraints, asset tangibility, and corporate investment. Review of Financial Studies 20, 1429-60.

Almeida, H., M. Campello, and C. Liu, 2006. The financial accelerator: evidence from international housing markets. Review of Finance 3, 1-32.

Amore, M., Schneider, C., Zaldokas, A., 2013. Credit supply and corporate innovation. Journal of Financial Economics 109, 835-855.

Atanassov, J., V. Nanda, and A. Seru. 2007. Finance and innovation: The case of publicly traded Firms. Working Paper, University of Oregon.

Bao, J. and A. Kolasinski, 2014. Why do firms issue secured debt? Unpublished working paper.

Barro, R., 1976. The loan market, collateral, and rates of interest. Journal of Money, Credit, and Banking 8: 439-56.

Bena, J. and K. Li, 2014. Corporate innovations and mergers and acquisitions, Journal of Finance 5, 1923-1960.

Benfratello, L., Schiantarelli, F., Sembenelli, A., 2008. Banks and innovation: Microeconometric evidence on Italian firms. Journal of Financial Economics 90, 197-217.

Benmelech, E., and N. Bergman, 2009. Collateral pricing. Journal of Financial Economics 123: 1635-77.

Benmelech, E., M. Garmaize, and T. Moskowitz, 2005. Do liquidation values affect financial contracts? Evidence from commercial loan contracts and zoning regulations. Quarterly Journal of Economics 120, 1121-54.

Benson, D., and R. Ziedonis, 2010. Corporate venture capital and the returns to acquiring portfolio companies. Journal of Financial Economics 98, 479-499.

Berger, P., and E. Ofek, 1995. Diversification's effect on firm value. Journal of Financial Economics 37, 39-65. 
Berger, A. and G. Udell, 1995. Relationship lending and lines of credit in small firm finance. Journal of Business 68, 351-81.

Bernanke, B. and M. Gertler, 1989. Agency costs, net worth, and business fluctuations. American Economic Review 79: 14-31.

Bernstein, S, 2014. Does going public affect innovation? Journal of Finance. Forthcoming.

Bhattacharya, S., Ritter, J., 1983. Innovation and Communication: Signalizing with Partial disclosure. Review of Economic Studies 50, 331-346.

Boot, A., A. Thakor, and Udell. 1991. Secured lending and default risk: equilibrium analysis, policy implications and empirical results 101, 458-72.

Brown, J., G. Martinsson, and B. Petersen, 2012. Do financing constraints matter for R\&D? European Economic Review 56, 1512-29.

Brown, J., S. Fazzari, and B. Petersen, 2009. Financing innovation and growth: Cash flow, external equity, and the 1990s R\&D boom. Journal of Finance 64, 151-185.

Brueggeman W., and J. Fisher, 2010. Real estate finance and investments. McGraw-Hill/Irwin, fourteenth edition.

Cao, J., J. Goh, F. Jiang, and Y. Yu, 2014. Corporate real estate collateral and innovation. Unpublished working paper.

Chaney, T., D. Sraer, and D. Thesmar, 2012. The collateral channel: How real estate shocks affect corporate investment? American Economic Review 102, 2381-2409.

Chan, Y. and A. Thakor, 1987. Collateral and competitive equilibria with moral hazard and private information. Journal of Finance 42, 345-63.

Chava, S., Oettl, A., Subramanian, A., Subramanian, K., 2013. Banking deregulation and innovation. Journal of Financial Economics 109, 759-774.

Chemmanur, T., E. Loutskina, and X. Tian, 2013. Corporate venture capital, value creation, and innovation. Review of Financial Studies 27, 2434-2473.

Chen, T., J. Harford, and C. Lin, 2013, Financial flexibility and corporate cash policy. Unpublished Working Paper.

Chesbrough, H. W. 2002. Making Sense of Corporate Venture Capital. Harvard Business Review March: 4-11.

Chesbrough H. and C. Tucci, 2004. Corporate venture capital in the context of corporate innovation. Unpublished working paper.

Cornaggia, J., Y. Mao, X. Tian, and B. Wolfe, 2013. Does banking competition affect innovation? Journal of Financial Economics, forthcoming.

Cvijanovic, D. 2014. Real estate prices and firm capital structure. Review of Financial Studies, forthcoming.

Dushnitsky G. and M. J. Lenox, 2005, When do incumbents learn from entrepreneurial ventures? Corporate venture capital and investing firm innovation rates. Research Policy 34, 615-639.

Dushnitsky G. and M. J. Lenox, 2006. When does corporate venture capital investment create firm value? Journal of Business Venturing 21, 753-772. 
Fulgeier, P. and M. Sevilir, 1009. Organization and financing of innovation, and the choice between corporate and independent venture capital. Journal of Financial and Quantitative Analysis 44, 12-91.

Gan, J., 2007. Collateral, debt capacity, and corporate investment: Evidence from a natural experiment. Journal of Financial Economics 85, 709-34.

Gao, H., P. Hsu, and K. Li, 2014. Managerial Short-Termism and Corporate Innovation Strategies. Unpublished Working Paper.

Garcia, D., and O. Norli, 2012. Geographic dispersions and stock returns. Journal of Financial Economics 106, 547-565.

Gertner, R., D. Scharfstein, and J. Stein, 1994. Internal versus external capital markets. Quarterly Journal of Economics 109: 1211-1230.

Glaeser, E., J. Gyourko, and A. Saiz, 2008. Symposium: Mortgages and the housing crash: housing supply and housing bubbles. Journal of Urban Economics 64: 198-216.

Grilliches, Z., A. Pakes, and B. Hall, 1988. The value of patents as indicators of inventive activity. Unpublished working paper.

Gompers, P. 2002. Corporations and the financing of innovation: The corporate venturing experience. In P. Gompers (editor), The Atlanta Federal Reserve Bank Conference Volume.

Gompers, P., and J. Lerner. 2000. The determinants of corporate venture capital success: organizational structure, incentives, and complementarities. In R. Morck (editor), Concentrated Ownership, University of Chicago Press.

Graham, J., Harvey, and C., Rajgopal, S., 2005. The economic implications of corporate financial reporting. Journal of Accounting and Economics 40, 3-73.

Hadlock, C., M. Ryngaert, and S. Thomas, 2001. Corporate structure and equity offerings: are there benefits to diversification? Journal of Business 74: 194-199.

Hall, B. H. and J. Lerner, 2010. The financing of R\&D and innovation. Handbook of the Economics of Innovation, ed. Bronwyn H. Hall and Nathan Rosenberg. Elsevier-North Holland.

Hall, B., A. Jaffe, and M. Trajtenberg, 2001. The NBER patent citation data file: Lessons, insights and methodological tools, NBER Working paper.

Hall, B., A. Jaffe, and M. Trajtenberg, 2005. Market value and patent citations. Rand Journal of Economics 36, 16-38.

He, J., and X. Tian, 2013. The dark side of analyst coverage: The case of innovation. Journal of Financial Economics 109, 856-878.

Higgins, M. and D. Rodriguez, 2006. The outsourcing of R\&D through acquisitions in the pharmaceutical industry. Journal of Financial Economics 80, $351-383$.

Himmelberg, C., C. Mayer, and T. Sinai, 2005. Assessing high house prices: Bubbles, fundamentals and misperceptions. Journal of Economic Perspectives 19, 67-92.

Holmstrom, B., 1989. Agency costs and innovation. Journal of Economic Behavior and Organization 12, 305-327.

Hombert, J., Matray, A., 2013. The real effects of hurting lending relationships: Evidence from banking deregulation and innovation. Unpublished working paper. HEC Paris. 
Hsu, Po-Hsuan, Tian, Xuan, and Yan, Xu, 2014. Financial development and innovation: Crosscountry evidence, Journal of Financial Economics 112 (1), 116-135.

Jensen, M., and W. Meckling, 1976. Theory of the firm: Managerial behavior, agency costs, and ownership structure. Journal of Financial Economics 3:305.60.

Jimenez, G., J. Salas, J. Saurina, 2006. Determinates of collateral. Journal of Financial Economics 81, 255-281.

Kerr, W., and R. Nanda, 2014. Financing innovation. Unpublished working paper.

Knight, F., 1921. Risk, uncertainty, and profit. Boston, MA: Houghton Mifflin.

Kogan, L., D. Papanikolaou, A. Seru, and N. Stoffman, 2012. Technological innovation, resource allocation, and growth. Unpublished working paper.

Lach, S., Schankerman, M. (1988). Dynamics of R\&D and investment in the scientific sector. Journal of Political Economy 97, 880-904.

Lamont, O., and C. Polk, 2002. Does diversification destroy value? Evidence from the industry shocks. Journal of Financial Economics 63, 51-77.

Lerner, J., 2012. The architecture of innovation: the economics of creative organizations. Harvard Business Review Press, Cambridge.

Lerner, J., M. Sorensen, and P. Stromberg, 2011. Private equity and long-run investment: the case of innovation. Journal of Finance 66: 445-477.

Lin, L., 2014. Collateral and the choice between bank debt and public debt. Management science, Forthcoming.

Mann, W., 2014.Creditor rights and innovation: evidence from patent collateral. Unpublished Working Paper.

Maksimovic and Pichler, 2001. Technological innovation and initial public offerings. Review of Financial Studies 14: 459-494.

Manso, G., 2011. Motivating innovation. Journal of Finance 66, 1823-1860.

Mao, Y., X. Tian, and X. Yu, 2013. Unleashing innovation. Unpublished working paper.

Matthews, R. and D. Robinson. 2008. Market structure, internal capital markets, and the boundaries of the firm. Journal of Finance 63, 2703-2736.

Matvos, G., and A. Seru, 2014. Resource allocation within firms and financial market dislocation: evidence from diversified conglomerates. Review of Financial Studies, forthcoming.

Mian, A. and A. Sufi, 2011. House Prices, home equity-based borrowing, and the US household leverage crisis. American Economic Review 101, 2132-56.

Myers, S. C. 1977. Determinants of corporate borrowing. Journal of Financial Economics 5:147175.

Nanda, R., and T. Nicholas, 2014. Did bank distress stifle innovation during the Great Depression? Journal of Financial Economics 114, 273-292.

Nanda, R., and M. Rhodes-Kropf, 2013. Investment cycles and startup innovation. Journal of Financial Economics 110, 403-418.

Nanda, R., and M. Rhodes-Kropf, 2014. Financing risk and innovation. Unpublished Working Paper. 
Porter, M., 1992. Capital disadvantage: America's failing capital investment system. Harvard Business Review 70, 65-82.

Rampini, A., and S. Viswanathan, 2013. Collateral and capital structure. Journal of Financial Economics 109, 466-492.

Robb, A., and D. Robinson, 2012. The capital structure decisions of new firms. Review of Financial Studies.

Robinson, D., 2008. Strategic alliances and the boundaries of the firm. Review of Financial Studies 21: 649-681.

Saiz, A., 2010. The geographic determinants of housing supply. Quarterly Journal of Economics 125 (23): 1253-96.

Scharfstein, D. and J. Stein, 2000. The dark side of internal capital markets: Divisional rent seeking and inefficient investment. Journal of Finance 55: 2537-2564.

Scherer, F. and D. Harhoff, 2000. Technology policy for a world of skew-distributed outcomes. Reseach Policy 29, 559-566.

Schumpeter, J., 1911. The theory of economic development. Harvard University Press, Cambridge, MA.

Seru, A., 2014, Firm boundaries matter: Evidence from conglomerates and R\&D activity, Journal of Financial Economics 111, 381-405.

Sevilir, M. and X. Tian. 2012. Acquiring innovation. Unpublished working paper.

Shleifer, A., and R. Vishny, 1992. Liquidation values and debt capacity: a market equilibrium approach. Journal of Finance, 1343-1366.

Solow, R. 1957. Technological change and the aggregate production function. Review of Economics and Statistics 39: 312-320.

Stein, J., 1997. Internal capital markets and the competition for corporate resources. Journal of Finance 52, 111-133.

Stein. J., 2003. Agency, information and corporate investment. In: Constantinides, G., Harris, M., Stuz, R. (Eds.), Handbook of the Economics of Finance, Elsevier, North Holland, pp. 111-165.

Stiglitz, J. and A. Weiss, 1981. Credit rationing in markets with imperfect information. American Economic Review 71 (3): 393-410.

Stiglitz, J., 1985. Credit markets and capital control. Journal of Money, Credit and Banking 17, $133-152$.

Stulz, R., H. Johnson, 1985. An analysis of secured debt. Journal of Financial Economics 14, 501-521.

Trajtenberg, M., Henderson, R., and Jaffe, A., 1997. University versus Corporate Patents: A Window on the Basicness of Invention. Economics of Innovation and New Technology 5, 19-50.

Zhao, X., 2009. Technological innovation and acquisitions. Management Science 55, 1170-1183. 


\section{Appendix: Variable Definitions and Data Sources}

\begin{tabular}{|c|c|}
\hline Variable & Definition \\
\hline \multicolumn{2}{|c|}{ Measures of innovation } \\
\hline LnPat $_{t+1 \sim t+5}$ & $\begin{array}{l}\text { Ln }\left(\frac{1+\text { Patent } t+1 \sim t+5}{\text { beginning-of-year book assets }}\right) \text {, where Patent } \\
t+1 \sim t+5 \\
\text { total number of patents a firm filed (and eventually granted) in } \\
\text { the subsequent five years. }\end{array}$ \\
\hline LnCitePat $_{t+1 \sim t+5}$ & $\begin{array}{l}\text { Ln }\left(\frac{1+\text { CitePat }}{\text { beginning-of }- \text { year book assets }}\right) \text {, where CitePat } \\
t+1 \sim t+5 \\
\text { total number of citations received on a firm's patents filed (and } \\
\text { eventually granted) scaled by the number of by the number of the } \\
\text { patents filed (and eventually granted) in the subsequent five } \\
\text { years. }\end{array}$ \\
\hline $\operatorname{LnPat}_{t+i}$ & $\begin{array}{l}\text { Ln }\left(\frac{1+\text { Patent }_{t+i}}{\text { beginning-of-year book assets }}\right) \text {, where Patent } \\
t+i \\
\text { number of patents a firm filed (and eventually granted) in year } \\
t+\mathrm{i} \text {. }\end{array}$ \\
\hline LnCitePat $_{t+i}$ & $\begin{array}{l}\text { Ln }\left(\frac{1+\text { CitePat }_{t+i}}{\text { beginning-of-year book assets }}\right) \text {, where CitePat } \\
t+i \\
\text { number of citations received on a firm's patents filed (and } \\
\text { eventually granted) scaled by the number of by the number of the } \\
\text { patents filed (and eventually granted) in year } \mathrm{t}+\mathrm{i} \text {. }\end{array}$ \\
\hline Generality $_{t+i}$ & $\begin{array}{l}\text { One minus the Herfindahl index of the three-digit technology } \\
\text { class distribution of all the patents that cite a given patent. I then } \\
\text { take the average for all patents generated by a firm in year } \mathrm{t}+\mathrm{i} \text {. }\end{array}$ \\
\hline Originality $_{t+i}$ & $\begin{array}{l}\text { One minus the Herfindahl index of the three-digit technology } \\
\text { class distribution of all the patents that a given patent cites. I then } \\
\text { take the average for all patents generated by a firm in year } \mathrm{t}+\mathrm{i} \text {. }\end{array}$ \\
\hline \multicolumn{2}{|c|}{ Measures of real estate } \\
\hline ReValue & $\begin{array}{l}\text { The market value of real estate assets normalized by book value } \\
\text { of assets (See Section } 3.2 .2 \text { for the construction of the variable) } \\
\text { at the beginning of a year for a firm in a given year. This variable } \\
\text { is constructed using industrial commercial real estate prices at } \\
\text { the MSA level and the state level. The market value of real estate } \\
\text { is measured in millions of dollars. }\end{array}$ \\
\hline ReOwn & $\begin{array}{l}\text { The interaction of a dummy that equals to } 1 \text { when a firm initially } \\
\text { owns real estate assets and the real estate price index. }\end{array}$ \\
\hline MSA Prices & $\begin{array}{l}\text { Industrial commercial real estate prices at the MSA level in a } \\
\text { given year. }\end{array}$ \\
\hline OccupancyRate & $\begin{array}{l}\text { The number of units in a building that have been rented out as a } \\
\text { ratio of the total number of units in the building. It is measured at } \\
\text { national level in a given year. }\end{array}$ \\
\hline Elasticity & $\begin{array}{l}\text { Local housing supply elasticity at the MSA level in a given year } \\
\text { (Saiz (2010)). }\end{array}$ \\
\hline \multicolumn{2}{|c|}{ Measures of acquisitions } \\
\hline AcqVol (Innov) & $\begin{array}{l}\text { Transaction value of "innovative" acquisition deals (measured in } \\
\text { millions of dollars) undertaken by a firm in a given year scaled }\end{array}$ \\
\hline
\end{tabular}


by beginning-of-year assets. "Innovative" acquisition deals refer to acquisitions refer to acquisitions where targets produce at least one patent prior to acquisition.

The number of "innovative" acquisition deals undertaken by a firm in a given year. "Innovative" acquisition deals refer to acquisitions where targets produce at least one patent prior to acquisition.

\begin{tabular}{ll}
\hline Measures of CVC investment & \\
\hline CvcVol & The amount of investment undertaken by CVC fund of a firm in \\
a given year scaled by beginning-of-year assets. \\
The numbers of deals undertaken by CVC fund of a firm in a \\
given year.
\end{tabular}




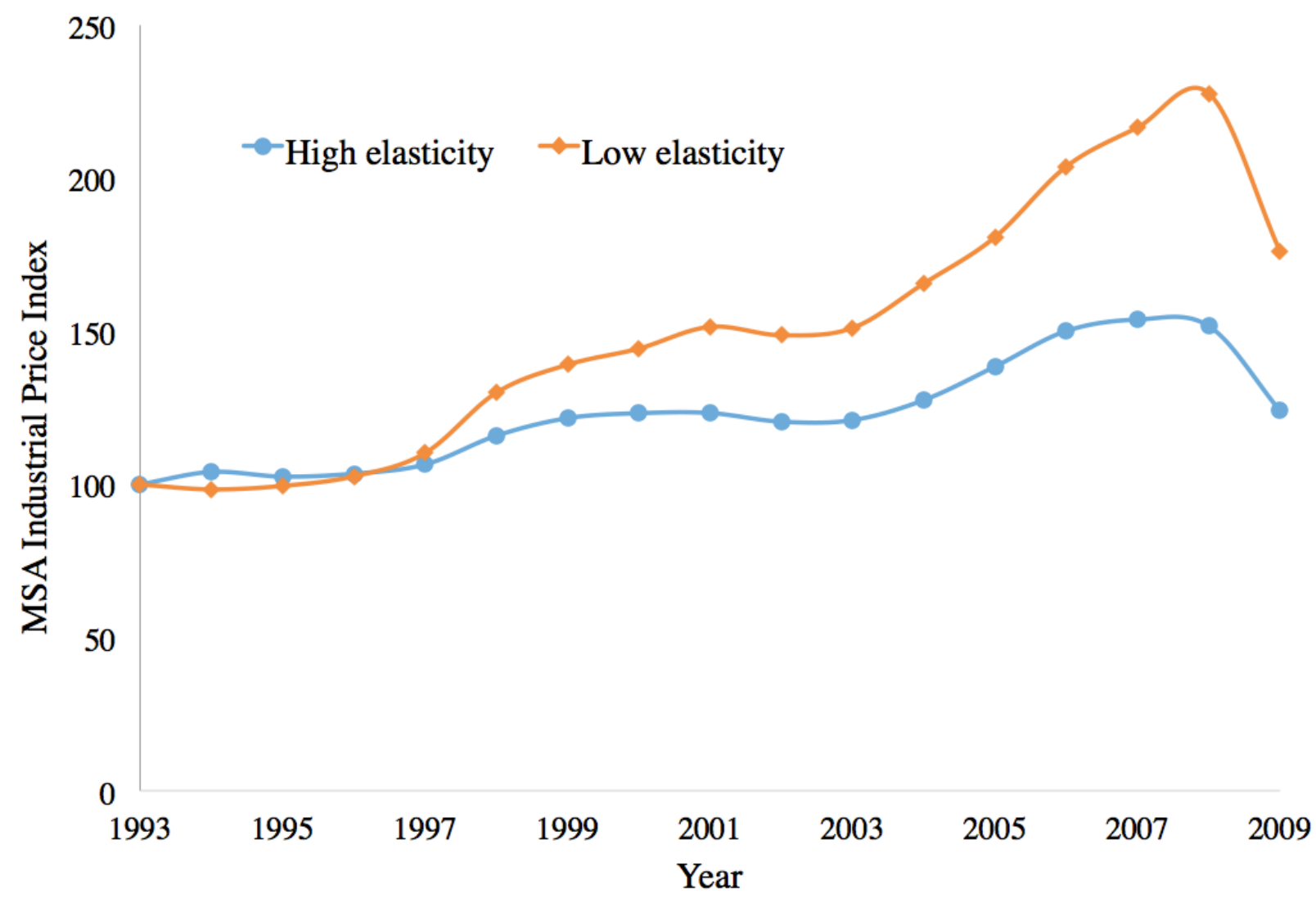

Figure 1. Relative evolution of industrial prices (high versus low elasticity MSA, 1993-2009). This figure shows the average industrial price index (normalized to 100 in 1993) for MSAs in the bottom quartile of land supply elasticity ("Low elasticity") and MSAs in the top quartile of land supply elasticity ("High elasticity"). 
Table 1

Summary Statistics

This table reports the summary statistics for firm-year observations of the variables used in the paper. The definitions of variables are listed in the Appendix.

Panel A: Firm-year level variables

\begin{tabular}{|c|c|c|c|c|c|c|}
\hline Variable & Mean & Median & SD & $25^{\text {th }}$ & $75^{\text {th }}$ & $\mathrm{N}$ \\
\hline \multicolumn{7}{|l|}{ Innovation variables } \\
\hline Pat & 8.387 & 0 & 23.861 & 0 & 3.247 & 18,312 \\
\hline CitePat & 5.843 & 0 & 10.873 & 0 & 7.585 & 18,312 \\
\hline \multicolumn{7}{|c|}{ Real estate variables } \\
\hline ReValue & 0.232 & 0.092 & 0.324 & 0 & 0.344 & 15,077 \\
\hline MSA Prices & 0.679 & 0.661 & 0.209 & 0.503 & 0.820 & 15,547 \\
\hline Elasticity & 1.099 & 0.860 & 0.618 & 0.650 & 1.180 & 15,686 \\
\hline \multicolumn{7}{|c|}{ Acquisition variables } \\
\hline AcqCount & 0.395 & 0 & 1.015 & 0 & 0 & 18,312 \\
\hline AcqCount (Innov) & 0.049 & 0 & 0.251 & 0 & 0 & 18,312 \\
\hline AcqVol & 0.043 & 0 & 0.177 & 0 & 0 & 16,615 \\
\hline AcqVol (Innov) & 0.011 & 0 & 0.102 & 0 & 0 & 17,848 \\
\hline \multicolumn{7}{|c|}{ CVC variables (for the subsample of firms with CVC programs) } \\
\hline CvcCount & 1.110 & 0 & 2.455 & 0 & 1 & 1,643 \\
\hline CveVol & 0.001 & 0 & 0.005 & 0 & 0 & 1,626 \\
\hline \multicolumn{7}{|l|}{ Other variables } \\
\hline Rd & 0.089 & 0.035 & 0.122 & 0 & 0.123 & 18,058 \\
\hline CashAssets & 0.100 & 0.120 & 0.183 & 0.035 & 0.200 & 17,961 \\
\hline$R O A$ & -0.011 & 0.068 & 0.237 & -0.039 & 0.127 & 18,128 \\
\hline Leverage & 0.208 & 0.174 & 0.195 & 0.023 & 0.329 & 18,143 \\
\hline Hindex & 0.159 & 0.086 & 0.201 & 0.016 & 0.219 & 18,312 \\
\hline InstOwn & 0.336 & 0.279 & 0.314 & 0 & 0.611 & 16,478 \\
\hline TobinQ & 2.267 & 1.642 & 1.657 & 1.174 & 2.641 & 17,449 \\
\hline SaleAssets & 1.178 & 1.120 & 0.639 & 0.742 & 1.563 & 18,012 \\
\hline Age & 20 & 18 & 12 & 10 & 33 & 18,312 \\
\hline Assets (million) & 1,217 & 153 & 2,472 & 30.773 & 899.877 & 18,199 \\
\hline PPEAssets & 0.262 & 0.234 & 0.180 & 0.112 & 0.373 & 18,023 \\
\hline NetLtIssue & 0.013 & 0 & 0.074 & -0.017 & 0.014 & 16,840 \\
\hline StIssue & 0.001 & 0 & 0.019 & 0 & 0 & 18,058 \\
\hline LtSecureD & 0.054 & 0.001 & 0.100 & 0.000 & 0.053 & 16,548 \\
\hline NetStkIssue & 0.039 & 0 & 0.168 & -0.023 & 0.011 & 16,134 \\
\hline NetFinancing & 0.006 & 0 & 0.020 & 0 & 0 & 15,136 \\
\hline
\end{tabular}


Panel B: Geographic distribution of firms

\begin{tabular}{cc}
\hline State & \% of Firms \\
\hline AL & $0.43 \%$ \\
AZ & $0.86 \%$ \\
CA & $19.90 \%$ \\
CO & $2.14 \%$ \\
CT & $3.00 \%$ \\
DC & $0.12 \%$ \\
DE & $0.37 \%$ \\
FL & $2.63 \%$ \\
GA & $2.57 \%$ \\
IA & $0.43 \%$ \\
ID & $0.06 \%$ \\
IL & $5.39 \%$ \\
IN & $1.47 \%$ \\
KS & $0.55 \%$ \\
KY & $0.37 \%$ \\
LA & $0.31 \%$ \\
MA & $7.16 \%$ \\
MD & $1.84 \%$ \\
MI & $3.37 \%$ \\
MN & $3.98 \%$ \\
MO & $1.59 \%$ \\
MT & $0.06 \%$ \\
NC & $2.27 \%$ \\
NH & $0.24 \%$ \\
NJ & $5.88 \%$ \\
NV & $0.80 \%$ \\
NY & $6.92 \%$ \\
OH & $4.16 \%$ \\
OK & $0.37 \%$ \\
OR & $1.41 \%$ \\
PA & $4.72 \%$ \\
RI & $0.37 \%$ \\
SC & $0.49 \%$ \\
TN & $0.86 \%$ \\
TX & $5.76 \%$ \\
UT & $0.86 \%$ \\
VA & $2.20 \%$ \\
VT & $0.06 \%$ \\
WI & $2.08 \%$ \\
\hline & $1.96 \%$ \\
\hline WA & \\
\hline
\end{tabular}




\section{Table 2:}

First-stage regression

This table reports the first-stage regression results. The dependent variable is the percentage change of industrial commercial real estate price. The independent variable the interaction of real occupancy rate interacted with the local elasticity of land supply developed by Siaz (2010). Definitions of variables are listed in the Appendix. Robust standard errors clustered by MSA are displayed in parentheses. ${ }^{* * *}, * *$, and $*$ indicate significance at the $1 \%, 5 \%$, and $10 \%$ level, respectively.

\begin{tabular}{lc}
\hline Dep. Var. & MSA Price Changes \\
\hline$\frac{1}{\text { Elasticity }} \times$ OccupancyRate & \\
& $0.010^{* * *}$ \\
Year FE & $(0.002)$ \\
MSA FE & Yes \\
Observations & Yes \\
Adjusted $\mathrm{R}^{2}$ & 1,953 \\
\hline
\end{tabular}




\section{Table 3}

Patent count and citations per patent

This table reports the effect of collateral shocks on patent counts and citations per patent. In Panel A1, the dependent variable is $L_{n P a t} t_{t+1 \sim t+5}$. In Panel A2, the dependent variable is $L_{n P a t} t_{t+i}$. In Panel B1, the dependent variable is LnCitePat $_{t+1 \sim t+5}$. In Panel B2, the dependent variable is LnCitePat $_{t+i}$. In Panels A1 and B1, column (1) - (3) presents OLS regression results, and column (4) - (6) presents IV regression estimates. In Panels A2 and B2, all columns present IV estimates. Init. Controls $\times$ RePrice are fixed effects computed as firm-level initial characteristics (five quintiles of age, asset, ROA, two-digit industry, and state of headquarter location) interacted with industrial commercial real estate prices. Definitions of variables are listed in the Appendix. In the IV specifications, standard errors are bootstrapped within MSAyear level, and are displayed in parentheses. $* * *, * *$, and $*$ indicate significance at the $1 \%, 5 \%$, and $10 \%$ level, respectively. 
Panel A1: Aggregate patents in subsequent five years

\begin{tabular}{|c|c|c|c|c|c|c|}
\hline \multirow[t]{3}{*}{ Dep. Var. } & \multicolumn{6}{|c|}{ LnPat $_{t+1 \sim t+5}$} \\
\hline & \multicolumn{3}{|c|}{ OLS } & \multicolumn{3}{|c|}{ IV } \\
\hline & (1) & $(2)$ & (3) & (4) & (5) & (6) \\
\hline ReValue & $\begin{array}{c}2.125 * * * \\
(0.096)\end{array}$ & $\begin{array}{c}2.271 * * * \\
(0.098)\end{array}$ & $\begin{array}{c}0.821 * * * \\
(0.114)\end{array}$ & $\begin{array}{c}2.088 * * * \\
(0.093)\end{array}$ & $\begin{array}{c}2.222 * * * \\
(0.096)\end{array}$ & $\begin{array}{c}0.767 * * * \\
(0.111)\end{array}$ \\
\hline CashAssets & & & $\begin{array}{c}0.834 * * * \\
(0.101)\end{array}$ & & & $\begin{array}{c}0.830 * * * \\
(0.100)\end{array}$ \\
\hline Leverage & & & $\begin{array}{c}-0.156^{* *} \\
(0.077)\end{array}$ & & & $\begin{array}{c}-0.179 * * \\
(0.077)\end{array}$ \\
\hline$R O A$ & & & $\begin{array}{c}0.238 * * \\
(0.100)\end{array}$ & & & $\begin{array}{c}0.254 * * * \\
(0.098)\end{array}$ \\
\hline TobinQ & & & $\begin{array}{c}0.123 * * * \\
(0.008)\end{array}$ & & & $\begin{array}{c}0.124 * * * \\
(0.008)\end{array}$ \\
\hline Hindex & & & $\begin{array}{c}0.079 \\
(0.134)\end{array}$ & & & $\begin{array}{c}0.041 \\
(0.135)\end{array}$ \\
\hline Hindex Squared & & & $\begin{array}{l}-0.072 \\
(0.202)\end{array}$ & & & $\begin{array}{c}0.022 \\
(0.203)\end{array}$ \\
\hline InstOwn & & & $\begin{array}{c}-0.541 * * * \\
(0.076)\end{array}$ & & & $\begin{array}{c}-0.578 * * * \\
(0.078)\end{array}$ \\
\hline LnAge & & & $\begin{array}{c}-0.363 * * * \\
(0.107)\end{array}$ & & & $\begin{array}{l}-0.151 \\
(0.128)\end{array}$ \\
\hline PPEAssets & & & $\begin{array}{c}1.400 * * * \\
(0.102)\end{array}$ & & & $\begin{array}{c}1.449 * * * \\
(0.100)\end{array}$ \\
\hline LnSales & & & $\begin{array}{c}-0.604 * * * \\
(0.022)\end{array}$ & & & $\begin{array}{c}-0.605 * * * \\
(0.023)\end{array}$ \\
\hline MSA Prices & & $\begin{array}{c}-14.290 * * * \\
(5.045)\end{array}$ & $\begin{array}{c}-11.501 * * \\
(5.172)\end{array}$ & & $\begin{array}{c}0.226 \\
(3.431)\end{array}$ & $\begin{array}{c}1.906 \\
(4.137)\end{array}$ \\
\hline Init. Controls $\times$ RePrice & NO & YES & YES & NO & YES & YES \\
\hline Firm FE & YES & YES & YES & YES & YES & YES \\
\hline Year FE & YES & YES & YES & YES & YES & YES \\
\hline Observations & 12,223 & 11,917 & 11,376 & 12,223 & 11,917 & 11,376 \\
\hline Adjusted $\mathrm{R}^{2}$ & 0.828 & 0.843 & 0.864 & 0.828 & 0.846 & 0.866 \\
\hline
\end{tabular}


Panel A2: Patents by individual years

\begin{tabular}{|c|c|c|c|c|c|}
\hline \multirow[t]{3}{*}{ Dep. Var. } & \multicolumn{5}{|c|}{$\operatorname{LnPat}_{t+i}$} \\
\hline & $t+1$ & $t+2$ & $t+3$ & $\mathrm{t}+4$ & $t+5$ \\
\hline & $(1)$ & (2) & (3) & (4) & $(5)$ \\
\hline ReValue & $\begin{array}{c}0.716^{* * *} \\
(0.092)\end{array}$ & $\begin{array}{c}0.790 * * * \\
(0.091)\end{array}$ & $\begin{array}{c}0.838^{* * *} \\
(0.086)\end{array}$ & $\begin{array}{c}0.947 * * * \\
(0.089)\end{array}$ & $\begin{array}{c}0.988 * * * \\
(0.097)\end{array}$ \\
\hline CashAssets & $\begin{array}{c}0.810^{* * *} \\
(0.089)\end{array}$ & $\begin{array}{c}0.685^{* * *} \\
(0.093)\end{array}$ & $\begin{array}{c}0.814 * * * \\
(0.094)\end{array}$ & $\begin{array}{c}0.848^{* * * *} \\
(0.098)\end{array}$ & $\begin{array}{c}0.778 * * * \\
(0.084)\end{array}$ \\
\hline Leverage & $\begin{array}{c}-0.155^{* *} \\
(0.070)\end{array}$ & $\begin{array}{c}-0.145^{* *} \\
(0.070)\end{array}$ & $\begin{array}{c}-0.146^{* *} \\
(0.070)\end{array}$ & $\begin{array}{l}-0.102 \\
(0.067)\end{array}$ & $\begin{array}{l}-0.025 \\
(0.069)\end{array}$ \\
\hline$R O A$ & $\begin{array}{c}0.081 \\
(0.091)\end{array}$ & $\begin{array}{c}0.310^{* * * *} \\
(0.097)\end{array}$ & $\begin{array}{c}0.179 * * \\
(0.090)\end{array}$ & $\begin{array}{c}0.223^{* *} \\
(0.095)\end{array}$ & $\begin{array}{c}0.268 * * * \\
(0.089)\end{array}$ \\
\hline Tobin $Q$ & $\begin{array}{c}0.125 * * * \\
(0.007)\end{array}$ & $\begin{array}{c}0.139 * * * \\
(0.008)\end{array}$ & $\begin{array}{c}0.127 * * * \\
(0.007)\end{array}$ & $\begin{array}{c}0.118 * * * \\
(0.007)\end{array}$ & $\begin{array}{c}0.103 * * * \\
(0.008)\end{array}$ \\
\hline Hindex & $\begin{array}{c}0.085 \\
(0.109)\end{array}$ & $\begin{array}{l}-0.115 \\
(0.111)\end{array}$ & $\begin{array}{c}0.100 \\
(0.114)\end{array}$ & $\begin{array}{c}0.021 \\
(0.118)\end{array}$ & $\begin{array}{c}0.002 \\
(0.121)\end{array}$ \\
\hline Hindex Squared & $\begin{array}{c}0.079 \\
(0.153)\end{array}$ & $\begin{array}{l}0.306^{*} \\
(0.165)\end{array}$ & $\begin{array}{c}-0.006 \\
(0.165)\end{array}$ & $\begin{array}{c}0.094 \\
(0.169)\end{array}$ & $\begin{array}{c}0.010 \\
(0.181)\end{array}$ \\
\hline InstOwn & $\begin{array}{c}-0.215 * * * \\
(0.061)\end{array}$ & $\begin{array}{c}-0.428 * * * \\
(0.061)\end{array}$ & $\begin{array}{c}-0.540^{* * *} \\
(0.063)\end{array}$ & $\begin{array}{c}-0.586 * * * \\
(0.063)\end{array}$ & $\begin{array}{c}-0.583 * * * \\
(0.066)\end{array}$ \\
\hline LnAge & $\begin{array}{c}-0.303 * * * \\
(0.104)\end{array}$ & $\begin{array}{c}-0.258 * * \\
(0.103)\end{array}$ & $\begin{array}{c}-0.260 * * \\
(0.110)\end{array}$ & $\begin{array}{c}-0.207^{*} \\
(0.114)\end{array}$ & $\begin{array}{c}-0.304 * * * \\
(0.116)\end{array}$ \\
\hline PPEAssets & $\begin{array}{c}1.485^{* * * *} \\
(0.092)\end{array}$ & $\begin{array}{c}1.480 * * * \\
(0.094)\end{array}$ & $\begin{array}{c}1.407 * * * \\
(0.095)\end{array}$ & $\begin{array}{c}1.421 * * * \\
(0.091)\end{array}$ & $\begin{array}{c}1.380 * * * \\
(0.096)\end{array}$ \\
\hline LnSales & $\begin{array}{c}-0.563 * * * \\
(0.021)\end{array}$ & $\begin{array}{c}-0.594 * * * \\
(0.021)\end{array}$ & $\begin{array}{c}-0.612 * * * \\
(0.021)\end{array}$ & $\begin{array}{c}-0.636^{* * * *} \\
(0.021)\end{array}$ & $\begin{array}{c}-0.656^{* * * *} \\
(0.022)\end{array}$ \\
\hline MSA Prices & $\begin{array}{c}2.132 \\
(2.488)\end{array}$ & $\begin{array}{c}1.231 \\
(2.497)\end{array}$ & $\begin{array}{c}2.724 \\
(2.377)\end{array}$ & $\begin{array}{c}5.070^{* *} \\
(2.574)\end{array}$ & $\begin{array}{c}9.832 * * * \\
(2.534)\end{array}$ \\
\hline Init. Controls $\times$ RePrice & YES & YES & YES & YES & YES \\
\hline Firm FE & YES & YES & YES & YES & YES \\
\hline Year FE & YES & YES & YES & YES & YES \\
\hline Observations & 12,690 & 12,690 & 12,607 & 12,006 & 11,376 \\
\hline Adjusted $\mathrm{R}^{2}$ & 0.874 & 0.869 & 0.872 & 0.877 & 0.884 \\
\hline
\end{tabular}


Panel B1: Citations per patent in subsequent five years

\begin{tabular}{|c|c|c|c|c|c|c|}
\hline \multirow[t]{3}{*}{ Dep. Var. } & \multicolumn{6}{|c|}{ LnCitePat $_{t+1 \sim t+5}$} \\
\hline & \multicolumn{3}{|c|}{ OLS } & \multicolumn{3}{|c|}{ IV } \\
\hline & (1) & (2) & (3) & (4) & (5) & (6) \\
\hline ReValue & $\begin{array}{c}2.332 * * * \\
(0.092)\end{array}$ & $\begin{array}{c}2.545^{* * * *} \\
(0.088)\end{array}$ & $\begin{array}{c}0.933 * * * \\
(0.111)\end{array}$ & $\begin{array}{c}2.311^{* * *} \\
(0.086)\end{array}$ & $\begin{array}{c}2.500 * * * \\
(0.088)\end{array}$ & $\begin{array}{c}0.886^{* * *} \\
(0.109)\end{array}$ \\
\hline CashAssets & & & $\begin{array}{c}0.834^{* * *} \\
(0.119)\end{array}$ & & & $\begin{array}{c}0.832 * * * \\
(0.118)\end{array}$ \\
\hline Leverage & & & $\begin{array}{l}-0.097 \\
(0.084)\end{array}$ & & & $\begin{array}{l}-0.092 \\
(0.084)\end{array}$ \\
\hline$R O A$ & & & $\begin{array}{l}0.199^{*} \\
(0.115)\end{array}$ & & & $\begin{array}{l}0.215^{*} \\
(0.114)\end{array}$ \\
\hline Tobin $Q$ & & & $\begin{array}{c}0.132 * * * \\
(0.009)\end{array}$ & & & $\begin{array}{c}0.135 * * * \\
(0.009)\end{array}$ \\
\hline Hindex & & & $\begin{array}{l}0.269^{* *} \\
(0.132)\end{array}$ & & & $\begin{array}{c}0.271 * * \\
(0.131)\end{array}$ \\
\hline Hindex Squared & & & $\begin{array}{c}-0.525^{* * * *} \\
(0.181)\end{array}$ & & & $\begin{array}{c}-0.528^{* * *} \\
(0.177)\end{array}$ \\
\hline InstOwn & & & $\begin{array}{c}-0.616^{* * *} \\
(0.076)\end{array}$ & & & $\begin{array}{c}-0.619 * * * \\
(0.078)\end{array}$ \\
\hline LnAge & & & $\begin{array}{c}-0.844^{* * * *} \\
(0.123)\end{array}$ & & & $\begin{array}{c}-0.972 * * * \\
(0.149)\end{array}$ \\
\hline PPEAssets & & & $\begin{array}{c}1.562 * * * \\
(0.120)\end{array}$ & & & $\begin{array}{c}1.553 * * * \\
(0.121)\end{array}$ \\
\hline LnSales & & & $\begin{array}{c}-0.651 * * * \\
(0.026)\end{array}$ & & & $\begin{array}{c}-0.655^{* * * *} \\
(0.026)\end{array}$ \\
\hline MSA Prices & & $\begin{array}{c}0.679 \\
(4.918)\end{array}$ & $\begin{array}{c}5.480 \\
(7.126)\end{array}$ & & $\begin{array}{c}8.877 * * * \\
(2.173)\end{array}$ & $\begin{array}{c}15.243 * * * \\
(2.839)\end{array}$ \\
\hline Init. Controls $\times$ RePrice & NO & YES & YES & $\mathrm{NO}$ & YES & YES \\
\hline Firm FE & YES & YES & YES & YES & YES & YES \\
\hline Year FE & YES & YES & YES & YES & YES & YES \\
\hline Observations & 12,223 & 11,917 & 11,376 & 12,223 & 11,917 & 11,376 \\
\hline Adjusted $\mathrm{R}^{2}$ & 0.851 & 0.870 & 0.892 & 0.852 & 0.872 & 0.893 \\
\hline
\end{tabular}


Panel B2: Citations per patent by individual years

\begin{tabular}{|c|c|c|c|c|c|}
\hline \multirow[t]{3}{*}{ Dep. Var. } & \multicolumn{5}{|c|}{ LnCitePat $_{t+1 \sim t+5}$} \\
\hline & $t+1$ & $t+2$ & $t+3$ & $t+4$ & $t+5$ \\
\hline & $(1)$ & (2) & (3) & (4) & $(5)$ \\
\hline ReValue & $\begin{array}{c}0.780 * * * \\
(0.103)\end{array}$ & $\begin{array}{c}0.867 * * * \\
(0.107)\end{array}$ & $\begin{array}{c}0.859^{* * *} \\
(0.101)\end{array}$ & $\begin{array}{c}0.980 * * * \\
(0.095)\end{array}$ & $\begin{array}{c}1.057^{* * *} \\
(0.101)\end{array}$ \\
\hline CashAssets & $\begin{array}{c}0.925^{* * *} \\
(0.132)\end{array}$ & $\begin{array}{c}0.751 * * * \\
(0.116)\end{array}$ & $\begin{array}{c}0.928^{* * *} \\
(0.118)\end{array}$ & $\begin{array}{c}0.964 * * * \\
(0.111)\end{array}$ & $\begin{array}{c}0.731^{* * *} \\
(0.108)\end{array}$ \\
\hline Leverage & $\begin{array}{l}-0.109 \\
(0.094)\end{array}$ & $\begin{array}{l}-0.075 \\
(0.088)\end{array}$ & $\begin{array}{l}-0.126 \\
(0.081)\end{array}$ & $\begin{array}{l}-0.118 \\
(0.078)\end{array}$ & $\begin{array}{c}0.014 \\
(0.078)\end{array}$ \\
\hline$R O A$ & $\begin{array}{c}0.149 \\
(0.130)\end{array}$ & $\begin{array}{c}0.277^{* *} \\
(0.121)\end{array}$ & $\begin{array}{c}0.049 \\
(0.119)\end{array}$ & $\begin{array}{c}0.138 \\
(0.110)\end{array}$ & $\begin{array}{c}0.291^{* * *} \\
(0.108)\end{array}$ \\
\hline Tobin $Q$ & $\begin{array}{c}0.134 * * * \\
(0.010)\end{array}$ & $\begin{array}{c}0.142 * * * \\
(0.010)\end{array}$ & $\begin{array}{c}0.136 * * * \\
(0.009)\end{array}$ & $\begin{array}{c}0.119 * * * \\
(0.008)\end{array}$ & $\begin{array}{c}0.098 * * * \\
(0.010)\end{array}$ \\
\hline Hindex & $\begin{array}{l}0.265^{*} \\
(0.158)\end{array}$ & $\begin{array}{c}0.065 \\
(0.142)\end{array}$ & $\begin{array}{c}0.099 \\
(0.133)\end{array}$ & $\begin{array}{c}0.050 \\
(0.127)\end{array}$ & $\begin{array}{c}0.247 * * \\
(0.123)\end{array}$ \\
\hline Hindex Squared & $\begin{array}{l}-0.143 \\
(0.206)\end{array}$ & $\begin{array}{l}-0.053 \\
(0.197)\end{array}$ & $\begin{array}{l}-0.186 \\
(0.184)\end{array}$ & $\begin{array}{l}-0.061 \\
(0.180)\end{array}$ & $\begin{array}{c}-0.426^{* *} \\
(0.179)\end{array}$ \\
\hline InstOwn & $\begin{array}{c}-0.354 * * * \\
(0.074)\end{array}$ & $\begin{array}{c}-0.556 * * * \\
(0.072)\end{array}$ & $\begin{array}{c}-0.626^{* * *} \\
(0.069)\end{array}$ & $\begin{array}{c}-0.667 * * * \\
(0.068)\end{array}$ & $\begin{array}{c}-0.631 * * * \\
(0.071)\end{array}$ \\
\hline LnAge & $\begin{array}{c}-0.227^{*} \\
(0.131)\end{array}$ & $\begin{array}{c}-0.418^{* * *} \\
(0.134)\end{array}$ & $\begin{array}{c}-0.507 * * * \\
(0.136)\end{array}$ & $\begin{array}{c}-0.582 * * * \\
(0.157)\end{array}$ & $\begin{array}{c}-0.782 * * * \\
(0.156)\end{array}$ \\
\hline PPEAssets & $\begin{array}{c}1.320^{* * *} \\
(0.125)\end{array}$ & $\begin{array}{c}1.568^{* * * *} \\
(0.125)\end{array}$ & $\begin{array}{c}1.590 * * * \\
(0.123)\end{array}$ & $\begin{array}{c}1.362 * * * \\
(0.109)\end{array}$ & $\begin{array}{c}1.305^{* * *} \\
(0.114)\end{array}$ \\
\hline LnSales & $\begin{array}{c}-0.613 * * * \\
(0.028)\end{array}$ & $\begin{array}{c}-0.627 * * * \\
(0.026)\end{array}$ & $\begin{array}{c}-0.637 * * * \\
(0.028)\end{array}$ & $\begin{array}{c}-0.667 * * * \\
(0.027)\end{array}$ & $\begin{array}{c}-0.701 * * * \\
(0.028)\end{array}$ \\
\hline MSA Prices & $\begin{array}{c}6.190^{* *} \\
(2.716)\end{array}$ & $\begin{array}{c}7.831 * * * \\
(2.466)\end{array}$ & $\begin{array}{c}10.297 * * * \\
(2.211)\end{array}$ & $\begin{array}{c}14.127 * * * \\
(2.203)\end{array}$ & $\begin{array}{c}17.288 * * * \\
(1.927)\end{array}$ \\
\hline Init. Controls $\times$ RePrice & YES & YES & YES & YES & YES \\
\hline Firm FE & YES & YES & YES & YES & YES \\
\hline Year FE & YES & YES & YES & YES & YES \\
\hline Observations & 12,690 & 12,690 & 12,607 & 12,006 & 11,376 \\
\hline Adjusted $\mathrm{R}^{2}$ & 0.847 & 0.856 & 0.872 & 0.886 & 0.897 \\
\hline
\end{tabular}




\section{Table 4}

Originality and generality

This table reports the effect of collateral shocks on patent novelty. The dependent variable is patent originality in panel A, and patent generality in panel B. All columns present IV estimates. Init. Controls $\times$ RePrice are fixed effects computed as firm-level initial characteristics (five quintiles of age, asset, ROA, two-digit industry, and state of headquarter location) interacted with industrial commercial real estate prices. Definitions of variables are listed in the Appendix. Standard errors are bootstrapped within MSA-year level, and are displayed in parentheses. $* * *, * *$, and $*$ indicate significance at the $1 \%, 5 \%$, and $10 \%$ level, respectively. 
Panel A: Patent originality

\begin{tabular}{|c|c|c|c|c|c|}
\hline \multirow[t]{3}{*}{ Dep. Var } & \multicolumn{5}{|c|}{ Originality } \\
\hline & $\mathrm{t}+1$ & $t+2$ & $\mathrm{t}+3$ & $\mathrm{t}+4$ & $t+5$ \\
\hline & (1) & (2) & (3) & (4) & (5) \\
\hline \multirow[t]{2}{*}{ ReValue } & 0.047 & $0.063^{*}$ & $0.068^{*}$ & $0.097 * *$ & $0.122^{* *}$ \\
\hline & $(0.036)$ & $(0.035)$ & $(0.037)$ & $(0.043)$ & $(0.052)$ \\
\hline \multirow[t]{2}{*}{ CashAssets } & 0.021 & -0.016 & 0.027 & $-0.062 *$ & 0.013 \\
\hline & $(0.030)$ & $(0.036)$ & $(0.034)$ & $(0.038)$ & $(0.045)$ \\
\hline \multirow[t]{2}{*}{ Leverage } & -0.018 & 0.003 & 0.018 & 0.000 & $-0.084 * *$ \\
\hline & $(0.027)$ & $(0.030)$ & $(0.030)$ & $(0.031)$ & $(0.041)$ \\
\hline \multirow[t]{2}{*}{$R O A$} & -0.018 & -0.008 & 0.015 & -0.008 & -0.080 \\
\hline & $(0.036)$ & $(0.045)$ & $(0.037)$ & $(0.053)$ & $(0.056)$ \\
\hline \multirow[t]{2}{*}{ TobinQ } & 0.000 & -0.002 & 0.001 & 0.004 & -0.004 \\
\hline & $(0.003)$ & $(0.003)$ & $(0.003)$ & $(0.004)$ & $(0.003)$ \\
\hline \multirow[t]{2}{*}{ Hindex } & 0.035 & 0.058 & 0.020 & 0.006 & -0.075 \\
\hline & $(0.047)$ & $(0.048)$ & $(0.049)$ & $(0.056)$ & $(0.061)$ \\
\hline \multirow[t]{2}{*}{ Hindex Squared } & -0.018 & -0.085 & 0.019 & 0.003 & 0.139 \\
\hline & $(0.068)$ & $(0.069)$ & $(0.071)$ & $(0.091)$ & $(0.098)$ \\
\hline \multirow[t]{2}{*}{ InstOwn } & 0.005 & -0.021 & -0.017 & -0.002 & 0.018 \\
\hline & $(0.021)$ & $(0.027)$ & $(0.027)$ & $(0.028)$ & $(0.035)$ \\
\hline \multirow[t]{2}{*}{ LnAge } & -0.047 & $-0.098 * *$ & -0.061 & -0.036 & -0.005 \\
\hline & $(0.038)$ & $(0.040)$ & $(0.047)$ & $(0.046)$ & $(0.049)$ \\
\hline \multirow[t]{2}{*}{ PPEAssets } & 0.022 & 0.043 & -0.026 & 0.002 & -0.014 \\
\hline & $(0.036)$ & $(0.039)$ & $(0.041)$ & $(0.045)$ & $(0.051)$ \\
\hline \multirow[t]{2}{*}{ LnSales } & -0.000 & -0.000 & 0.002 & 0.010 & -0.010 \\
\hline & $(0.009)$ & $(0.009)$ & $(0.009)$ & $(0.011)$ & $(0.011)$ \\
\hline \multirow[t]{2}{*}{ MSA Prices } & $-5.204 * *$ & $-15.480 * * *$ & $-28.559 * * *$ & $-57.801 * * *$ & $175.910 * * *$ \\
\hline & (2.139) & $(2.980)$ & (9.949) & $(2.318)$ & $(6.447)$ \\
\hline \multicolumn{6}{|l|}{ Init. Controls $\times$} \\
\hline RePrice & YES & YES & YES & YES & YES \\
\hline Firm FE & YES & YES & YES & YES & YES \\
\hline Year FE & YES & YES & YES & YES & YES \\
\hline Observations & 5,482 & 4,862 & 4,215 & 3,605 & 3,013 \\
\hline Adjusted $\mathrm{R}^{2}$ & 0.548 & 0.551 & 0.582 & 0.591 & 0.619 \\
\hline
\end{tabular}


Panel C: Patent generality

\begin{tabular}{|c|c|c|c|c|c|}
\hline \multirow[t]{3}{*}{ Dep. Var } & \multicolumn{5}{|c|}{ Generality } \\
\hline & $t+1$ & $\mathrm{t}+2$ & $t+3$ & $t+4$ & $t+5$ \\
\hline & (1) & (2) & (3) & (4) & (5) \\
\hline \multirow[t]{2}{*}{ ReValue } & 0.008 & 0.064 & 0.110 & 0.040 & 0.111 \\
\hline & $(0.060)$ & $(0.067)$ & $(0.079)$ & $(0.098)$ & $(0.133)$ \\
\hline \multirow[t]{2}{*}{ CashAssets } & 0.023 & -0.055 & -0.061 & -0.029 & -0.057 \\
\hline & $(0.054)$ & $(0.055)$ & $(0.072)$ & $(0.085)$ & $(0.089)$ \\
\hline \multirow[t]{2}{*}{ Leverage } & 0.042 & 0.022 & 0.053 & 0.023 & 0.084 \\
\hline & $(0.038)$ & $(0.051)$ & $(0.061)$ & $(0.077)$ & $(0.102)$ \\
\hline \multirow[t]{2}{*}{$R O A$} & $0.147^{* * *}$ & 0.055 & 0.072 & 0.099 & -0.011 \\
\hline & $(0.056)$ & $(0.069)$ & $(0.087)$ & $(0.088)$ & $(0.120)$ \\
\hline \multirow{2}{*}{ TobinQ } & -0.002 & 0.004 & 0.005 & -0.001 & -0.006 \\
\hline & $(0.004)$ & $(0.004)$ & $(0.005)$ & $(0.007)$ & $(0.009)$ \\
\hline \multirow[t]{2}{*}{ Hindex } & 0.026 & -0.024 & $-0.246^{* * *}$ & 0.046 & -0.052 \\
\hline & $(0.068)$ & $(0.078)$ & $(0.093)$ & $(0.113)$ & $(0.157)$ \\
\hline \multirow[t]{2}{*}{ Hindex Squared } & 0.025 & -0.057 & $0.274 * *$ & -0.143 & 0.063 \\
\hline & $(0.109)$ & $(0.120)$ & $(0.134)$ & $(0.167)$ & $(0.271)$ \\
\hline \multirow[t]{2}{*}{ InstOwn } & 0.009 & 0.015 & 0.012 & -0.059 & -0.053 \\
\hline & $(0.033)$ & $(0.044)$ & $(0.045)$ & $(0.064)$ & $(0.081)$ \\
\hline \multirow[t]{2}{*}{ LnAge } & 0.026 & -0.027 & -0.004 & 0.025 & -0.137 \\
\hline & $(0.047)$ & $(0.060)$ & $(0.073)$ & $(0.080)$ & $(0.112)$ \\
\hline \multirow[t]{2}{*}{ PPEAssets } & -0.002 & 0.068 & 0.003 & 0.023 & -0.109 \\
\hline & $(0.052)$ & $(0.063)$ & $(0.073)$ & $(0.087)$ & $(0.127)$ \\
\hline \multirow[t]{2}{*}{ LnSales } & $-0.034 * * *$ & -0.006 & -0.014 & 0.013 & 0.032 \\
\hline & $(0.012)$ & $(0.015)$ & $(0.018)$ & $(0.026)$ & $(0.036)$ \\
\hline \multirow[t]{2}{*}{ MSA Prices } & $-5.443 * * *$ & $-15.326^{* * *}$ & $-38.915 * * *$ & -24.813 & $52.449 * * *$ \\
\hline & $(1.960)$ & (4.676) & $(8.960)$ & (22.611) & (15.984) \\
\hline \multicolumn{6}{|l|}{ Init. Controls $\times$} \\
\hline RePrice & YES & YES & YES & YES & YES \\
\hline Firm FE & YES & YES & YES & YES & YES \\
\hline Year FE & YES & YES & YES & YES & YES \\
\hline Observations & 4,239 & 3,622 & 3,002 & 2,416 & 1,861 \\
\hline Adjusted $\mathrm{R}^{2}$ & 0.538 & 0.557 & 0.588 & 0.613 & 0.649 \\
\hline
\end{tabular}




\section{Table 5}

Patent industry

This table reports the effect of collateral shocks on patent industry distribution. The dependent variable is the percentage of patents that are in a different 2-digit SIC industry from the incumbent firm. Since patent is typically not associated with an SIC code, but is instead assigned to a three-digit technology class by USPTO database, I use a concordance table that connects the USPTO technology classes to two-digit SIC code following Hsu, Tian and Xu (2014). All columns present IV estimates. Init. Controls $\times$ RePrice are fixed effects computed as firm-level initial characteristics (five quintiles of age, asset, ROA, two-digit industry, and state of headquarter location) interacted with industrial commercial real estate prices. Definitions of variables are listed in the Appendix. Standard errors are bootstrapped within MSA-year level, and are displayed in parentheses. $* * *, * *$, and $*$ indicate significance at the $1 \%, 5 \%$, and $10 \%$ level, respectively. 


\begin{tabular}{|c|c|c|c|c|c|}
\hline \multirow[t]{3}{*}{ Dep. Var } & \multicolumn{5}{|c|}{ Industry } \\
\hline & $\mathrm{t}+1$ & $\mathrm{t}+2$ & $\mathrm{t}+3$ & $\mathrm{t}+4$ & $\mathrm{t}+5$ \\
\hline & (1) & $(2)$ & (3) & (4) & $(5)$ \\
\hline ReValue & $\begin{array}{c}0.049 * * * \\
(0.010)\end{array}$ & $\begin{array}{c}0.046 * * * \\
(0.011)\end{array}$ & $\begin{array}{c}0.049 * * * \\
(0.012)\end{array}$ & $\begin{array}{c}0.045^{* * *} \\
(0.013)\end{array}$ & $\begin{array}{c}0.058 * * * \\
(0.016)\end{array}$ \\
\hline CashAssets & $\begin{array}{c}-0.159 * * * \\
(0.024)\end{array}$ & $\begin{array}{c}-0.159 * * * \\
(0.024)\end{array}$ & $\begin{array}{c}-0.121 * * * \\
(0.028)\end{array}$ & $\begin{array}{c}-0.110 * * * \\
(0.033)\end{array}$ & $\begin{array}{c}-0.072 * \\
(0.039)\end{array}$ \\
\hline Leverage & $\begin{array}{c}0.016 \\
(0.019)\end{array}$ & $\begin{array}{c}0.008 \\
(0.020)\end{array}$ & $\begin{array}{c}0.037 \\
(0.022)\end{array}$ & $\begin{array}{l}0.044^{*} \\
(0.024)\end{array}$ & $\begin{array}{l}0.050^{*} \\
(0.026)\end{array}$ \\
\hline$R O A$ & $\begin{array}{c}0.132 * * * \\
(0.025)\end{array}$ & $\begin{array}{c}0.133 * * * \\
(0.025)\end{array}$ & $\begin{array}{c}0.111 * * * \\
(0.029)\end{array}$ & $\begin{array}{c}0.110 * * * \\
(0.029)\end{array}$ & $\begin{array}{c}0.123 * * * \\
(0.036)\end{array}$ \\
\hline TobinQ & $\begin{array}{c}-0.012 * * * \\
(0.002)\end{array}$ & $\begin{array}{c}-0.012 * * * \\
(0.002)\end{array}$ & $\begin{array}{c}-0.010 * * * \\
(0.002)\end{array}$ & $\begin{array}{c}-0.012 * * * \\
(0.002)\end{array}$ & $\begin{array}{c}-0.010 * * * \\
(0.003)\end{array}$ \\
\hline Hindex & $\begin{array}{c}0.132 * * * \\
(0.031)\end{array}$ & $\begin{array}{c}0.101 * * * \\
(0.033)\end{array}$ & $\begin{array}{c}0.112 * * * \\
(0.036)\end{array}$ & $\begin{array}{c}0.113 * * * \\
(0.039)\end{array}$ & $\begin{array}{c}0.091 * * \\
(0.044)\end{array}$ \\
\hline Hindex Squared & $\begin{array}{c}-0.135^{* * *} \\
(0.036)\end{array}$ & $\begin{array}{c}-0.114 * * * \\
(0.037)\end{array}$ & $\begin{array}{c}-0.125^{* * *} \\
(0.041)\end{array}$ & $\begin{array}{c}-0.120 * * \\
(0.048)\end{array}$ & $\begin{array}{l}-0.091 \\
(0.056)\end{array}$ \\
\hline InstOwn & $\begin{array}{c}0.030 * * * \\
(0.009)\end{array}$ & $\begin{array}{c}0.033^{* * *} \\
(0.009)\end{array}$ & $\begin{array}{c}0.033 * * * \\
(0.011)\end{array}$ & $\begin{array}{c}0.043 * * * \\
(0.011)\end{array}$ & $\begin{array}{c}0.037 * * * \\
(0.012)\end{array}$ \\
\hline LnAge & $\begin{array}{l}-0.019 \\
(0.016)\end{array}$ & $\begin{array}{l}-0.019 \\
(0.016)\end{array}$ & $\begin{array}{l}-0.032 * \\
(0.018)\end{array}$ & $\begin{array}{l}-0.024 \\
(0.019)\end{array}$ & $\begin{array}{l}-0.019 \\
(0.022)\end{array}$ \\
\hline PPEAssets & $\begin{array}{c}0.004 \\
(0.019)\end{array}$ & $\begin{array}{l}-0.016 \\
(0.022)\end{array}$ & $\begin{array}{l}-0.029 \\
(0.024)\end{array}$ & $\begin{array}{l}-0.033 \\
(0.026)\end{array}$ & $\begin{array}{l}-0.052 * \\
(0.027)\end{array}$ \\
\hline LnSales & $\begin{array}{c}-0.001 \\
(0.003)\end{array}$ & $\begin{array}{c}-0.001 \\
(0.003)\end{array}$ & $\begin{array}{l}-0.001 \\
(0.003)\end{array}$ & $\begin{array}{l}-0.002 \\
(0.004)\end{array}$ & $\begin{array}{c}-0.004 \\
(0.004)\end{array}$ \\
\hline MSA Prices & $\begin{array}{c}-17.272 * * * \\
(0.252)\end{array}$ & $\begin{array}{c}-21.374 * * * \\
(0.475)\end{array}$ & $\begin{array}{l}-0.391 \\
(2.145)\end{array}$ & $\begin{array}{c}-3.049 * * \\
(1.192)\end{array}$ & $\begin{array}{c}-41.701 * * * \\
(4.085)\end{array}$ \\
\hline $\begin{array}{l}\text { Init. Controls } \times \\
\text { RePrice }\end{array}$ & YES & YES & YES & YES & YES \\
\hline Firm FE & YES & YES & YES & YES & YES \\
\hline Year FE & YES & YES & YES & YES & YES \\
\hline Observations & 5,566 & 4,928 & 4,268 & 3,645 & 3,040 \\
\hline Adjusted $\mathrm{R}^{2}$ & 0.638 & 0.639 & 0.633 & 0.633 & 0.640 \\
\hline
\end{tabular}


Table 6

Collateral shocks and innovative investment

This table investigates the effect of collateral shocks on innovation input. The dependent variable is $L n R D$ in column (1), LnCvcVol in column (2), LnCvcCount in column (3), LnAcqVol in column (4), LnAcqCount in column (5). The estimates are from IV regressions. All the independent variables are lagged by one year. Definitions of variables are in Appendix. In the IV specifications, standard errors are bootstrapped within MSA-year level, and are displayed in parentheses. $* * *, * *$, and $*$ indicate significance at the $1 \%, 5 \%$, and $10 \%$ level, respectively.

\begin{tabular}{|c|c|c|c|c|c|}
\hline Dep. Var & $\begin{array}{c}\operatorname{LnRD} \\
\text { (1) }\end{array}$ & $\begin{array}{c}\mathrm{LnCvcVol} \\
\text { (2) }\end{array}$ & $\begin{array}{c}\text { LnCvcCount } \\
\text { (3) }\end{array}$ & $\begin{array}{c}\text { LnAcqVol } \\
\text { (4) }\end{array}$ & $\begin{array}{c}\text { LnAcqCount } \\
\text { (5) }\end{array}$ \\
\hline ReValue & $\begin{array}{c}0.502 * * * \\
(0.070)\end{array}$ & $\begin{array}{c}0.910 * * * \\
(0.049)\end{array}$ & $\begin{array}{c}0.852 * * * \\
(0.143)\end{array}$ & $\begin{array}{c}0.939 * * * \\
(0.048)\end{array}$ & $\begin{array}{c}1.102 * * * \\
(0.103)\end{array}$ \\
\hline Cash & $\begin{array}{c}0.792 * * * \\
(0.079)\end{array}$ & $\begin{array}{c}0.664 * * * \\
(0.067)\end{array}$ & $\begin{array}{c}0.865 * * * \\
(0.117)\end{array}$ & $\begin{array}{c}0.641 * * * \\
(0.067)\end{array}$ & $\begin{array}{c}0.712 * * * \\
(0.092)\end{array}$ \\
\hline Leverage & $\begin{array}{l}-0.025 \\
(0.062)\end{array}$ & $\begin{array}{c}0.079 \\
(0.054)\end{array}$ & $\begin{array}{c}0.124 \\
(0.098)\end{array}$ & $\begin{array}{c}0.031 \\
(0.056)\end{array}$ & $\begin{array}{c}-0.159 * \\
(0.087)\end{array}$ \\
\hline$R O A$ & $\begin{array}{c}-1.142 * * * \\
(0.082)\end{array}$ & $\begin{array}{c}-0.809 * * * \\
(0.077)\end{array}$ & $\begin{array}{c}-1.115^{* * *} \\
(0.116)\end{array}$ & $\begin{array}{c}-0.771 * * * \\
(0.078)\end{array}$ & $\begin{array}{c}-0.819 * * * \\
(0.097)\end{array}$ \\
\hline TobinQ & $\begin{array}{c}0.110^{* * * *} \\
(0.005)\end{array}$ & $\begin{array}{c}0.079 * * * \\
(0.005)\end{array}$ & $\begin{array}{c}0.078 * * * \\
(0.013)\end{array}$ & $\begin{array}{c}0.081 * * * \\
(0.005)\end{array}$ & $\begin{array}{c}0.107 * * * \\
(0.011)\end{array}$ \\
\hline Hindex & $\begin{array}{c}0.029 \\
(0.088)\end{array}$ & $\begin{array}{c}0.064 \\
(0.064)\end{array}$ & $\begin{array}{c}0.039 \\
(0.149)\end{array}$ & $\begin{array}{c}0.049 \\
(0.061)\end{array}$ & $\begin{array}{l}-0.014 \\
(0.157)\end{array}$ \\
\hline Hindex Squared & $\begin{array}{c}0.089 \\
(0.136)\end{array}$ & $\begin{array}{l}-0.075 \\
(0.092)\end{array}$ & $\begin{array}{l}-0.053 \\
(0.218)\end{array}$ & $\begin{array}{l}-0.079 \\
(0.083)\end{array}$ & $\begin{array}{l}-0.147 \\
(0.246)\end{array}$ \\
\hline InstOwn & $\begin{array}{c}-0.229 * * * \\
(0.044)\end{array}$ & $\begin{array}{c}-0.587 * * * \\
(0.037)\end{array}$ & $\begin{array}{c}-0.557 * * * \\
(0.104)\end{array}$ & $\begin{array}{c}-0.536 * * * \\
(0.036)\end{array}$ & $\begin{array}{c}-0.474 * * * \\
(0.078)\end{array}$ \\
\hline LnAge & $\begin{array}{c}0.151 * * \\
(0.075)\end{array}$ & $\begin{array}{l}-0.011 \\
(0.057)\end{array}$ & $\begin{array}{l}-0.100 \\
(0.122)\end{array}$ & $\begin{array}{c}0.001 \\
(0.055)\end{array}$ & $\begin{array}{l}-0.007 \\
(0.096)\end{array}$ \\
\hline$P P E$ & $\begin{array}{c}-0.448 * * * \\
(0.066)\end{array}$ & $\begin{array}{c}-0.721 * * * \\
(0.058)\end{array}$ & $\begin{array}{c}-0.745^{* * *} \\
(0.141)\end{array}$ & $\begin{array}{c}-0.697 * * * \\
(0.058)\end{array}$ & $\begin{array}{c}-0.783 * * * \\
(0.099)\end{array}$ \\
\hline LnSales & $\begin{array}{c}-0.295 * * * \\
(0.017)\end{array}$ & $\begin{array}{c}-0.561 * * * \\
(0.020)\end{array}$ & $\begin{array}{c}-0.455^{* * *} \\
(0.034)\end{array}$ & $\begin{array}{c}-0.576 * * * \\
(0.020)\end{array}$ & $\begin{array}{c}-0.538 * * * \\
(0.025)\end{array}$ \\
\hline MSA Prices & $\begin{array}{c}-3.411 * * * \\
(0.650)\end{array}$ & $\begin{array}{l}-0.414 \\
(0.675)\end{array}$ & $\begin{array}{l}-1.578 \\
(1.065)\end{array}$ & $\begin{array}{l}-0.274 \\
(0.677)\end{array}$ & $\begin{array}{l}-1.395 \\
(1.129)\end{array}$ \\
\hline $\begin{array}{l}\text { Init. Controls } \times \\
\text { RePrice }\end{array}$ & YES & YES & YES & YES & YES \\
\hline Firm FE & YES & YES & YES & YES & YES \\
\hline Year FE & YES & YES & YES & YES & YES \\
\hline Observations & 11,451 & 11,451 & 11,441 & 11,451 & 11,314 \\
\hline Adjusted $\mathrm{R}^{2}$ & 0.956 & 0.976 & 0.806 & 0.976 & 0.854 \\
\hline
\end{tabular}




\section{Table 7}

Acquisitions

This table investigates the effect of collateral shocks on deal characteristics of acquisition. The regressions are run at deal-year level. The dependent variable in column (1) is CashPercent, which is the percentage of cash in the funding of an acquisition. The dependent variable in column (2) is a dummy variable --- CashDummy, which is equal to one if the acquisition is partially funded by cash and zero otherwise. The dependent variable in column (3) is a dummy variable --- TargetInd, which is equal to one if the target belongs to a different 2-digit SIC industry from the parent firm. The dependent variable in column (4) is TargetPat, which is number of patents filed by a target prior to acquisition. The dependent variable in column (5) is TargetCite, which is the number of citation received by the patents filed by the target prior to acquisition. The estimates are from IV regressions. All the independent variables are lagged by one year. Definitions of variables are in Appendix. In the IV specifications, standard errors are bootstrapped within MSA-year level, and are displayed in parentheses. ***, **, and * indicate significance at the $1 \%, 5 \%$, and $10 \%$ level, respectively. 


\begin{tabular}{|c|c|c|c|c|c|}
\hline Dep. Var & $\begin{array}{c}\text { CashPercent } \\
\text { (1) }\end{array}$ & $\begin{array}{c}\text { CashDummy } \\
\text { (2) }\end{array}$ & $\begin{array}{l}\text { TargetInd } \\
\text { (3) }\end{array}$ & $\begin{array}{c}\text { TargetPat } \\
(4)\end{array}$ & $\begin{array}{c}\text { TargetCite } \\
(5)\end{array}$ \\
\hline ReValue & $\begin{array}{c}0.268 * * * \\
(0.100)\end{array}$ & $\begin{array}{c}0.403 * * * \\
(0.107)\end{array}$ & $\begin{array}{l}0.199 * \\
(0.113)\end{array}$ & $\begin{array}{c}0.757 * * * \\
(0.285)\end{array}$ & $\begin{array}{l}0.804 * \\
(0.461)\end{array}$ \\
\hline CashAssets & $\begin{array}{c}0.041 \\
(0.150)\end{array}$ & $\begin{array}{l}-0.044 \\
(0.158)\end{array}$ & $\begin{array}{l}-0.245 * \\
(0.138)\end{array}$ & $\begin{array}{c}1.410 * * * \\
(0.276)\end{array}$ & $\begin{array}{c}1.480 * * * \\
(0.492)\end{array}$ \\
\hline Leverage & $\begin{array}{c}0.255 * * * \\
(0.096)\end{array}$ & $\begin{array}{c}0.287 * * * \\
(0.104)\end{array}$ & $\begin{array}{c}0.093 \\
(0.092)\end{array}$ & $\begin{array}{c}0.273 \\
(0.193)\end{array}$ & $\begin{array}{c}0.445 \\
(0.357)\end{array}$ \\
\hline$R O A$ & $\begin{array}{c}0.201 \\
(0.221)\end{array}$ & $\begin{array}{c}0.157 \\
(0.248)\end{array}$ & $\begin{array}{c}0.127 \\
(0.223)\end{array}$ & $\begin{array}{l}-0.749 \\
(0.559)\end{array}$ & $\begin{array}{l}-1.129 \\
(0.901)\end{array}$ \\
\hline TobinQ & $\begin{array}{l}-0.011 \\
(0.012)\end{array}$ & $\begin{array}{l}-0.010 \\
(0.013)\end{array}$ & $\begin{array}{c}0.001 \\
(0.012)\end{array}$ & $\begin{array}{c}0.129 * * * \\
(0.037)\end{array}$ & $\begin{array}{c}0.150 * * \\
(0.058)\end{array}$ \\
\hline Hindex & $\begin{array}{l}0.190 * \\
(0.100)\end{array}$ & $\begin{array}{c}0.164 \\
(0.107)\end{array}$ & $\begin{array}{c}0.107 \\
(0.113)\end{array}$ & $\begin{array}{c}0.229 \\
(0.253)\end{array}$ & $\begin{array}{c}0.236 \\
(0.445)\end{array}$ \\
\hline Hindex Squared & $\begin{array}{c}-0.298 * * \\
(0.125)\end{array}$ & $\begin{array}{c}-0.291 * * \\
(0.139)\end{array}$ & $\begin{array}{l}-0.094 \\
(0.145)\end{array}$ & $\begin{array}{l}-0.256 \\
(0.325)\end{array}$ & $\begin{array}{l}-0.393 \\
(0.550)\end{array}$ \\
\hline InstOwn & $\begin{array}{c}0.063 \\
(0.074)\end{array}$ & $\begin{array}{c}0.080 \\
(0.079)\end{array}$ & $\begin{array}{c}0.072 \\
(0.082)\end{array}$ & $\begin{array}{l}-0.180 \\
(0.178)\end{array}$ & $\begin{array}{l}-0.117 \\
(0.303)\end{array}$ \\
\hline LnAge & $\begin{array}{l}-0.013 \\
(0.104)\end{array}$ & $\begin{array}{l}-0.061 \\
(0.119)\end{array}$ & $\begin{array}{c}0.107 \\
(0.100)\end{array}$ & $\begin{array}{l}-0.295 \\
(0.182)\end{array}$ & $\begin{array}{l}-0.089 \\
(0.342)\end{array}$ \\
\hline PPEAssets & $\begin{array}{l}0.168 * \\
(0.097)\end{array}$ & $\begin{array}{l}0.214 * \\
(0.112)\end{array}$ & $\begin{array}{c}0.003 \\
(0.103)\end{array}$ & $\begin{array}{c}1.941 * * * \\
(0.261)\end{array}$ & $\begin{array}{c}2.177 * * * \\
(0.405)\end{array}$ \\
\hline LnSales & $\begin{array}{l}-0.036 \\
(0.024)\end{array}$ & $\begin{array}{l}-0.044 \\
(0.029)\end{array}$ & $\begin{array}{c}0.005 \\
(0.026)\end{array}$ & $\begin{array}{c}-0.809 * * * \\
(0.068)\end{array}$ & $\begin{array}{c}-0.871 * * * \\
(0.118)\end{array}$ \\
\hline MSA Prices & $\begin{array}{c}28.141 \\
(19.289)\end{array}$ & $\begin{array}{c}26.031 \\
(20.005)\end{array}$ & $\begin{array}{l}-2.415 \\
(2.619)\end{array}$ & $\begin{array}{c}3.897 \\
(7.376)\end{array}$ & $\begin{array}{c}-0.982 \\
(10.171)\end{array}$ \\
\hline $\begin{array}{l}\text { Init. Controls } \times \\
\text { RePrice }\end{array}$ & YES & YES & YES & YES & YES \\
\hline Firm FE & YES & YES & YES & YES & YES \\
\hline Year FE & YES & YES & YES & YES & YES \\
\hline Observations & 4,936 & 4,936 & 4,936 & 4,936 & 4,936 \\
\hline Adjusted $\mathrm{R}^{2}$ & 0.262 & 0.285 & 0.427 & 0.877 & 0.690 \\
\hline
\end{tabular}




\section{Table 8}

CVC investment

This table investigates the effect of collateral shocks on CVC investment. The regressions are run at deal-year level. The dependent variable in column (1) is a dummy variable, which is equal to one if the incumbent and the start-up firm operate in different two-digit SIC industries, and zero otherwise. The dependent variable in column (2) is the number of round the start-up firm is in when the incumbent firm invests in it. The dependent variable in column (3) is the age of the entrepreneurial firm when it receives funding from incumbents. The dependent variable in column (4) is a dummy variable, and it is equal to one if the startup went IPO and zero otherwise. The dependent variable in column (5) is a dummy variable, and it is equal to one if the startup was acquired or merged and zero otherwise. The dependent variable in column (6) is a dummy variable, and it is equal to one if the startup went bankrupt and zero otherwise. The estimates are from IV regressions. All the independent variables are lagged by one year. Definitions of variables are in Appendix. In the IV specifications, standard errors are bootstrapped within MSA-year level, and are displayed in parentheses. $* * *, * *$, and * indicate significance at the $1 \%$, $5 \%$, and $10 \%$ level, respectively. 


\begin{tabular}{|c|c|c|c|c|c|c|}
\hline \multirow[t]{2}{*}{ Dep. Var } & Industry & Round & Age & IPO exit & $M \& A$ exit & Bankruptcy \\
\hline & (1) & $(2)$ & $(3)$ & (4) & $(5)$ & $(6)$ \\
\hline ReValue & $\begin{array}{c}0.413 * * * \\
(0.148)\end{array}$ & $\begin{array}{l}-0.384^{*} \\
(0.229)\end{array}$ & $\begin{array}{c}-0.002 * * * \\
(0.001)\end{array}$ & $\begin{array}{c}-0.375 \\
(0.237)\end{array}$ & $\begin{array}{c}0.950 * * * \\
(0.304)\end{array}$ & $\begin{array}{c}-0.063 \\
(0.277)\end{array}$ \\
\hline CashAssets & $\begin{array}{c}0.442 \\
(0.287)\end{array}$ & $\begin{array}{c}-0.078 \\
(0.205)\end{array}$ & $\begin{array}{c}0.000 \\
(0.001)\end{array}$ & $\begin{array}{c}0.150 \\
(0.216)\end{array}$ & $\begin{array}{c}0.241 \\
(0.315)\end{array}$ & $\begin{array}{l}-0.245 \\
(0.181)\end{array}$ \\
\hline Leverage & $\begin{array}{l}0.297^{*} \\
(0.154)\end{array}$ & $\begin{array}{l}-0.211 * \\
(0.126)\end{array}$ & $\begin{array}{c}0.001 \\
(0.001)\end{array}$ & $\begin{array}{c}0.182 \\
(0.186)\end{array}$ & $\begin{array}{c}0.290 \\
(0.278)\end{array}$ & $\begin{array}{c}0.019 \\
(0.184)\end{array}$ \\
\hline$R O A$ & $\begin{array}{l}-0.597 \\
(0.425)\end{array}$ & $\begin{array}{c}-0.061 \\
(0.325)\end{array}$ & $\begin{array}{c}0.005 * * * \\
(0.002)\end{array}$ & $\begin{array}{c}0.130 \\
(0.357)\end{array}$ & $\begin{array}{l}-0.850 \\
(0.616)\end{array}$ & $\begin{array}{c}0.271 \\
(0.415)\end{array}$ \\
\hline TobinQ & $\begin{array}{c}0.010 \\
(0.013)\end{array}$ & $\begin{array}{c}0.010 \\
(0.012)\end{array}$ & $\begin{array}{c}0.000 \\
(0.000)\end{array}$ & $\begin{array}{c}-0.001 \\
(0.014)\end{array}$ & $\begin{array}{c}-0.039 * * \\
(0.018)\end{array}$ & $\begin{array}{c}0.019 \\
(0.012)\end{array}$ \\
\hline Hindex & $\begin{array}{c}-0.603 * * \\
(0.303)\end{array}$ & $\begin{array}{c}-0.467^{* *} \\
(0.218)\end{array}$ & $\begin{array}{c}0.000 \\
(0.001)\end{array}$ & $\begin{array}{c}0.308 \\
(0.227)\end{array}$ & $\begin{array}{l}-0.387 \\
(0.344)\end{array}$ & $\begin{array}{l}-0.231 \\
(0.260)\end{array}$ \\
\hline Hindex Squared & $\begin{array}{c}0.722 * * \\
(0.310)\end{array}$ & $\begin{array}{c}0.516^{*} \\
(0.275)\end{array}$ & $\begin{array}{l}-0.000 \\
(0.001)\end{array}$ & $\begin{array}{c}0.085 \\
(0.277)\end{array}$ & $\begin{array}{c}0.060 \\
(0.377)\end{array}$ & $\begin{array}{c}0.014 \\
(0.360)\end{array}$ \\
\hline InstOwn & $\begin{array}{c}-0.124 \\
(0.172)\end{array}$ & $\begin{array}{c}0.168 \\
(0.197)\end{array}$ & $\begin{array}{c}0.001 \\
(0.001)\end{array}$ & $\begin{array}{c}-0.229 \\
(0.242)\end{array}$ & $\begin{array}{c}-0.001 \\
(0.372)\end{array}$ & $\begin{array}{c}-0.002 \\
(0.266)\end{array}$ \\
\hline LnAge & $\begin{array}{l}-0.516 \\
(0.384)\end{array}$ & $\begin{array}{c}0.181 \\
(0.436)\end{array}$ & $\begin{array}{l}-0.001 \\
(0.003)\end{array}$ & $\begin{array}{l}-0.432 \\
(0.654)\end{array}$ & $\begin{array}{l}-0.115 \\
(0.797)\end{array}$ & $\begin{array}{c}0.300 \\
(0.508)\end{array}$ \\
\hline PPEAssets & $\begin{array}{c}-0.003 \\
(0.298)\end{array}$ & $\begin{array}{c}0.286 \\
(0.202)\end{array}$ & $\begin{array}{c}0.003 * * * \\
(0.001)\end{array}$ & $\begin{array}{c}0.021 \\
(0.278)\end{array}$ & $\begin{array}{c}-0.371 \\
(0.326)\end{array}$ & $\begin{array}{c}0.175 \\
(0.214)\end{array}$ \\
\hline LnSales & $\begin{array}{c}0.095 * * \\
(0.038)\end{array}$ & $\begin{array}{l}-0.069 \\
(0.056)\end{array}$ & $\begin{array}{c}-0.001 * * * \\
(0.000)\end{array}$ & $\begin{array}{c}-0.073 \\
(0.069)\end{array}$ & $\begin{array}{l}0.140 * \\
(0.081)\end{array}$ & $\begin{array}{l}-0.005 \\
(0.055)\end{array}$ \\
\hline MSA Prices & $\begin{array}{c}8.465 \\
(5.145)\end{array}$ & $\begin{array}{r}-10.733 \\
(7.326)\end{array}$ & $\begin{array}{l}- \\
-\end{array}$ & - & - & - \\
\hline $\begin{array}{l}\text { Init. Controls } \times \\
\text { RePrice }\end{array}$ & YES & YES & YES & YES & YES & YES \\
\hline Firm FE & YES & YES & YES & YES & YES & YES \\
\hline Year FE & YES & YES & YES & YES & YES & YES \\
\hline Observations & 1,175 & 1,605 & 1,145 & 1,285 & 1,285 & 1,285 \\
\hline Adjusted $\mathrm{R}^{2}$ & 0.409 & 0.144 & 0.796 & 0.275 & 0.164 & 0.169 \\
\hline
\end{tabular}


Table 9

Cross-sectional variations

This table reports the subsample tests for the effect of collateral shocks on patenting outcomes, based on secured debt, financial constraints, and the industries in Panel A to Panel C, respectively. The coefficient estimates in all panels are based on IV regressions.

In Panel A, the dependent variable is $L_{n P a t} t_{t+1 \sim t+5}$ in column (1) - (2), and LnCitePat $_{t+1 \sim t+5}$ in column (3) - (4). Secured debt category assignments use the ratio of long-term secured debt outstanding to total long-term debt outstanding in the current year, where firms above the median of the ratio are regarded as those with more collateral pledging and firms below the median are assigned as less collateral pledging firms.

In Panel B, the dependent variable is $L n P a t_{t+1 \sim t+5}$ in column (1) - (2), and LnCitePat $t_{t+1 \sim t+5}$ in column (3) - (4). As in Hall, Jaffe, and Trajtenberg (2005), more demanding industries include pharmaceutical, medical instrumentation, chemicals, computers, communications, and electrical industries, and the rest are classified as less demanding industries, which include software programming, internet applications, and other low-tech industries.

In Panel C1, the dependent variable is $\mathrm{LnPat}_{t+1 \sim t+5}$, and in Panel $\mathrm{C} 2$ the dependent variable is $\mathrm{LnCitePat}_{t+1 \sim t+5}$. Financial constraint assignments are based on firm dividend payout policy, firm size, and bond ratings. Firms not paying dividend are regarded as constrained firms, and firms paying dividend are unconstrained firms. Dividend payout ratio is computed as dividends on common stocks divided by income before extraordinary items adjusted for common stock equivalents. A firm is regarded as financially constrained if the size of its book assets falls in the bottom tercile of the whole distribution, and unconstrained if the size of its book assets falls in the top tercile of the whole distribution. Firms without bond rating (splticrm) are categorized as financially constrained, and financially unconstrained firms are those whose bonds are rated.

In Panel D, the dependent variable is $\mathrm{LnPat}_{t+1 \sim t+5}$ in column (1) - (2), and LnCitePat $t_{t+1 \sim t+5}$ in column (3) - (4). Cash holdings are measured as cash and all securities readily transferable to cash in the current asset section. A firm is regarded as with low cash holdings if the amount of its cash holdings falls in the bottom tercile of the whole distribution, and with high cash holdings if the amount of its cash holdings falls in the top tercile of the whole distribution.

In Panel E, the dependent variable is $\operatorname{LnPat}_{t+1 \sim t+5}$ in column (1) - (2), and LnCitePat $_{t+1 \sim t+5}$ in column (3) - (4). Local real estate volatility is measured by the standard deviation of annual commercial real estate prices in an MSA area in the past five years. If a firm is in an MSA area where historical local real estate price volatility is lower than median value, than the firm is assigned to the low group. If a firm is in an MSA area where historical local real estate price volatility is higher than median value, than the firm is assigned to the high group.

Init. Controls $\times$ RePrice are fixed effects computed as firm-level initial characteristics (five quintiles of age, asset, ROA, two-digit industry, and state of headquarter location) interacted with real estate prices.

Definitions of control variables are in the Appendix. Robust standard errors clustered by MSA $\times$ year are displayed in parentheses. $* * *, * *$, and * indicate significance at the $1 \%, 5 \%$, and $10 \%$ level, respectively. 
Panel A: Secured debt

\begin{tabular}{|c|c|c|c|c|}
\hline & \multicolumn{2}{|c|}{$\operatorname{LnPat}_{t+l \sim t+5}$} & \multicolumn{2}{|c|}{ LnCitePat $t_{+1 \sim t+5}$} \\
\hline & More secured & Less secured & More secured & Less secured \\
\hline & (1) & (2) & (3) & (4) \\
\hline \multirow[t]{2}{*}{ ReValue } & $1.264 * * *$ & $1.071 * * *$ & $1.227 * * *$ & $0.818 * * *$ \\
\hline & $(0.197)$ & $(0.238)$ & $(0.225)$ & $(0.169)$ \\
\hline \multirow[t]{2}{*}{ CashAssets } & $0.648 * * *$ & $0.768 * * *$ & $0.871 * * *$ & $0.761 * * *$ \\
\hline & $(0.196)$ & $(0.235)$ & $(0.208)$ & $(0.233)$ \\
\hline \multirow[t]{2}{*}{ Leverage } & -0.081 & 0.059 & -0.030 & -0.158 \\
\hline & $(0.157)$ & $(0.180)$ & $(0.175)$ & $(0.164)$ \\
\hline \multirow[t]{2}{*}{$R O A$} & 0.334 & 0.201 & 0.075 & 0.027 \\
\hline & $(0.213)$ & $(0.255)$ & $(0.234)$ & $(0.241)$ \\
\hline \multirow[t]{2}{*}{ Tobin $Q$} & $0.092 * * *$ & $0.115 * * *$ & $0.103 * * *$ & $0.109 * * *$ \\
\hline & $(0.016)$ & $(0.019)$ & $(0.016)$ & $(0.019)$ \\
\hline \multirow[t]{2}{*}{ Hindex } & 0.060 & $-0.450^{* *}$ & 0.261 & 0.017 \\
\hline & $(0.200)$ & $(0.229)$ & $(0.238)$ & $(0.209)$ \\
\hline \multirow{2}{*}{ Hindex Squared } & 0.278 & $0.747 * *$ & -0.185 & -0.414 \\
\hline & $(0.306)$ & $(0.316)$ & $(0.349)$ & $(0.277)$ \\
\hline \multirow[t]{2}{*}{ InstOwn } & $-0.503 * * *$ & $-0.445^{* * *}$ & $-0.689 * * *$ & -0.154 \\
\hline & $(0.148)$ & $(0.154)$ & $(0.156)$ & $(0.121)$ \\
\hline \multirow[t]{2}{*}{ LnAge } & $-0.464 * *$ & $0.871^{* *}$ & $-1.002 * * *$ & 0.127 \\
\hline & $(0.215)$ & $(0.351)$ & $(0.231)$ & $(0.316)$ \\
\hline \multirow[t]{2}{*}{ PPEAssets } & $1.497 * * *$ & $1.296 * * *$ & $1.589 * * *$ & $1.699 * * *$ \\
\hline & $(0.199)$ & $(0.226)$ & $(0.220)$ & $(0.207)$ \\
\hline \multirow[t]{2}{*}{ LnSales } & $-0.476 * * *$ & $-0.491 * * *$ & $-0.500 * * *$ & $-0.544 * * *$ \\
\hline & $(0.040)$ & $(0.055)$ & $(0.046)$ & $(0.053)$ \\
\hline \multirow[t]{2}{*}{ MSA Prices } & $11.820 * * *$ & $-16.229 * * *$ & $20.129 * * *$ & -3.617 \\
\hline & $(4.309)$ & $(5.400)$ & $(4.730)$ & $(3.815)$ \\
\hline Init. Controls $\times$ RePrice & YES & YES & YES & YES \\
\hline Firm FE & YEs & YEs & YEs & YEs \\
\hline Year FE & YES & YES & YES & YES \\
\hline Test " More = Less" & \multicolumn{2}{|c|}{$7.19 * * *$} & \multicolumn{2}{|c|}{$9.84 * * *$} \\
\hline Observations & 3,888 & 4,060 & 3,888 & 4,060 \\
\hline Adjusted $\mathrm{R}^{2}$ & 0.880 & 0.860 & 0.871 & 0.911 \\
\hline
\end{tabular}


Panel B: Innovation difficulty

\begin{tabular}{|c|c|c|c|c|}
\hline \multirow[t]{3}{*}{ Dep. Var. } & \multicolumn{2}{|c|}{$\operatorname{LnPat}_{t+1 \sim t+5}$} & \multicolumn{2}{|c|}{ LnCitePat $_{t+1 \sim t+5}$} \\
\hline & More demanding & Less demanding & More demanding & Less demanding \\
\hline & (1) & (2) & (3) & (4) \\
\hline \multirow[t]{2}{*}{ ReValue } & $0.818^{* * *}$ & $0.522 * * *$ & $1.117 * * *$ & 0.211 \\
\hline & $(0.128)$ & $(0.168)$ & $(0.118)$ & $(0.185)$ \\
\hline \multirow[t]{2}{*}{ CashAssets } & $0.856^{* * *}$ & $0.847 * * *$ & $0.808 * * *$ & $1.073^{* * *}$ \\
\hline & $(0.114)$ & $(0.209)$ & $(0.133)$ & $(0.256)$ \\
\hline \multirow[t]{2}{*}{ Leverage } & -0.027 & $-0.255^{*}$ & $0.173^{*}$ & $-0.341 * *$ \\
\hline & $(0.091)$ & $(0.145)$ & $(0.100)$ & $(0.151)$ \\
\hline \multirow[t]{2}{*}{$R O A$} & $0.374 * * *$ & 0.167 & $0.433 * * *$ & 0.080 \\
\hline & $(0.118)$ & $(0.199)$ & $(0.137)$ & $(0.245)$ \\
\hline \multirow[t]{2}{*}{ TobinQ } & $0.130^{* * *}$ & $0.101 * * *$ & $0.141 * * *$ & $0.123^{* * *}$ \\
\hline & $(0.009)$ & $(0.015)$ & $(0.010)$ & $(0.021)$ \\
\hline \multirow[t]{2}{*}{ Hindex } & 0.059 & 0.112 & 0.218 & 0.003 \\
\hline & $(0.169)$ & $(0.198)$ & $(0.175)$ & $(0.207)$ \\
\hline \multirow[t]{2}{*}{ Hindex Squared } & -0.008 & -0.241 & $-0.472 *$ & -0.192 \\
\hline & $(0.259)$ & $(0.310)$ & $(0.249)$ & $(0.301)$ \\
\hline \multirow[t]{2}{*}{ InstOwn } & $-0.702 * * *$ & $-0.459 * * *$ & $-0.902 * * *$ & $-0.469 * * *$ \\
\hline & $(0.092)$ & $(0.113)$ & $(0.087)$ & $(0.124)$ \\
\hline \multirow[t]{2}{*}{ LnAge } & $-0.608 * * *$ & $-0.185^{*}$ & $-0.991 * * *$ & $-0.690 * * *$ \\
\hline & $(0.077)$ & $(0.105)$ & $(0.070)$ & $(0.145)$ \\
\hline \multirow[t]{2}{*}{ PPEAssets } & $1.506 * * *$ & $1.564 * * *$ & $1.727 * * *$ & $1.597 * * *$ \\
\hline & $(0.128)$ & $(0.223)$ & $(0.142)$ & $(0.240)$ \\
\hline \multirow[t]{2}{*}{ LnSales } & $-0.615 * * *$ & $-0.692 * * *$ & $-0.615^{* * *}$ & $-0.830 * * *$ \\
\hline & $(0.026)$ & $(0.043)$ & $(0.031)$ & $(0.052)$ \\
\hline \multirow[t]{2}{*}{ MSA Prices } & $-1.378 * *$ & 0.118 & -0.591 & -0.681 \\
\hline & $(0.593)$ & $(0.707)$ & $(0.592)$ & $(0.666)$ \\
\hline Init. Controls $\times$ & YES & YES & YES & YES \\
\hline \multicolumn{5}{|l|}{ RePrice } \\
\hline Firm FE & YES & YES & YES & YES \\
\hline Year FE & YES & YES & YES & YES \\
\hline Test "More = Less" & \multicolumn{2}{|c|}{$8.41 * * *$} & \multicolumn{2}{|c|}{$7.15^{* * *}$} \\
\hline Observations & 7,216 & 4,442 & 7,216 & 4,442 \\
\hline Adjusted $\mathrm{R}^{2}$ & 0.829 & 0.869 & 0.880 & 0.881 \\
\hline
\end{tabular}


Panel C1: Ex-ante financing constraints - patents

\begin{tabular}{|c|c|c|c|c|c|c|}
\hline \multirow[t]{4}{*}{ Dep. Var. } & \multicolumn{6}{|c|}{$\operatorname{LnPat}_{t+1 \sim t+5}$} \\
\hline & \multicolumn{2}{|c|}{ Payout policy } & \multicolumn{2}{|c|}{ Firm size } & \multicolumn{2}{|c|}{ Bond ratings } \\
\hline & Const. & Unconst. & Const. & Unconst. & Const. & Unconst. \\
\hline & (1) & $(2)$ & (3) & (4) & (5) & (6) \\
\hline \multirow[t]{2}{*}{ ReValue } & $0.910 * * *$ & $0.864 * * *$ & $1.196 * * *$ & $0.666 * *$ & $1.674 * * *$ & $0.864 * * *$ \\
\hline & $(0.144)$ & $(0.208)$ & $(0.158)$ & $(0.290)$ & $(0.202)$ & $(0.132)$ \\
\hline \multirow[t]{2}{*}{ CashAssets } & $0.724 * * *$ & $1.875 * * *$ & $0.443 * * *$ & $0.885 * *$ & $0.828 * * *$ & $0.809 * * *$ \\
\hline & $(0.110)$ & $(0.338)$ & $(0.147)$ & $(0.343)$ & $(0.174)$ & $(0.129)$ \\
\hline \multirow[t]{2}{*}{ Leverage } & -0.141 & -0.040 & 0.059 & -0.125 & 0.155 & $-0.256 * * *$ \\
\hline & $(0.103)$ & $(0.176)$ & $(0.134)$ & $(0.216)$ & $(0.137)$ & $(0.095)$ \\
\hline \multirow[t]{2}{*}{$R O A$} & $0.318 * * *$ & -0.254 & $0.405 * * *$ & 0.491 & 0.056 & $0.324 * *$ \\
\hline & $(0.114)$ & $(0.441)$ & $(0.131)$ & $(0.564)$ & $(0.127)$ & $(0.125)$ \\
\hline \multirow[t]{2}{*}{ TobinQ } & $0.136 * * *$ & $0.039 * *$ & $0.113 * * *$ & $0.074 * * *$ & $0.090 * * *$ & $0.119 * * *$ \\
\hline & $(0.010)$ & $(0.020)$ & $(0.012)$ & $(0.024)$ & $(0.015)$ & $(0.009)$ \\
\hline \multirow[t]{2}{*}{ Hindex } & 0.081 & -0.017 & -0.004 & -0.218 & 0.351 & -0.040 \\
\hline & $(0.191)$ & $(0.214)$ & $(0.235)$ & $(0.288)$ & $(0.298)$ & $(0.145)$ \\
\hline \multirow[t]{2}{*}{ Hindex Squared } & -0.044 & -0.064 & 0.325 & -0.067 & -0.297 & -0.000 \\
\hline & $(0.306)$ & $(0.312)$ & $(0.366)$ & $(0.411)$ & $(0.494)$ & $(0.209)$ \\
\hline \multirow[t]{2}{*}{ InstOwn } & $-0.923 * * *$ & -0.132 & $-1.560 * * *$ & $-0.264 *$ & $-0.904 * * *$ & $-0.412 * * *$ \\
\hline & $(0.109)$ & $(0.136)$ & $(0.197)$ & $(0.141)$ & $(0.127)$ & $(0.088)$ \\
\hline \multirow[t]{2}{*}{ LnAge } & $-0.604 * * *$ & 0.344 & $-0.806 * * *$ & 0.400 & -0.246 & -0.111 \\
\hline & $(0.161)$ & $(0.307)$ & $(0.238)$ & $(0.353)$ & $(0.266)$ & $(0.156)$ \\
\hline \multirow[t]{2}{*}{ PPEAssets } & $1.711 * * *$ & $0.508 * *$ & $1.300 * * *$ & $1.266 * * *$ & $1.781 * * *$ & $1.357 * * *$ \\
\hline & $(0.147)$ & $(0.222)$ & $(0.201)$ & $(0.260)$ & $(0.174)$ & $(0.139)$ \\
\hline \multirow[t]{2}{*}{ LnSales } & $-0.578 * * *$ & $-0.430 * * *$ & $-0.520 * * *$ & $-0.454 * * *$ & $-0.699 * * *$ & $-0.573 * * *$ \\
\hline & $(0.028)$ & $(0.076)$ & $(0.044)$ & $(0.102)$ & $(0.041)$ & $(0.026)$ \\
\hline \multirow[t]{2}{*}{ MSA Prices } & -2.649 & -8.163 & $5.873 * *$ & $-45.852^{*}$ & 4.887 & 0.055 \\
\hline & (10.639) & $(7.671)$ & $(2.840)$ & $(26.814)$ & $(5.774)$ & $(2.692)$ \\
\hline Init. Controls $\times$ & YES & YES & YES & YES & YES & YES \\
\hline \multicolumn{7}{|l|}{ RePrice } \\
\hline Firm FE & YES & YES & YES & YES & YES & YES \\
\hline Year FE & YES & YES & YES & YES & YES & YES \\
\hline Test "C.=U." & \multicolumn{2}{|c|}{$6.39 * * *$} & \multicolumn{2}{|c|}{$4.66^{* * *}$} & \multicolumn{2}{|c|}{$12.35^{* * *}$} \\
\hline Observations & 5,901 & 4,551 & 3,352 & 3,410 & 3,566 & 7,810 \\
\hline Adjusted $\mathrm{R}^{2}$ & 0.850 & 0.856 & 0.761 & 0.841 & 0.887 & 0.879 \\
\hline
\end{tabular}


Panel C2: Ex-ante financing constraints - citations per patent

\begin{tabular}{|c|c|c|c|c|c|c|}
\hline \multirow[t]{4}{*}{ Dep. Var. } & \multicolumn{6}{|c|}{ LnCitePat ${ }_{t+1 \sim t+5}$} \\
\hline & \multicolumn{2}{|c|}{ Payout policy } & \multicolumn{2}{|c|}{ Firm size } & \multicolumn{2}{|c|}{ Bond ratings } \\
\hline & Const. & Unconst. & Const. & Unconst. & Const. & Unconst. \\
\hline & (1) & (2) & (3) & (4) & $(5)$ & (6) \\
\hline ReValue & $\begin{array}{c}1.156^{* * *} \\
(0.148)\end{array}$ & $\begin{array}{c}0.496 * * * \\
(0.166)\end{array}$ & $\begin{array}{c}1.154 * * * \\
(0.222)\end{array}$ & $\begin{array}{c}0.533 * * * \\
(0.171)\end{array}$ & $\begin{array}{c}1.552 * * * \\
(0.214)\end{array}$ & $\begin{array}{c}0.940 * * * \\
(0.118)\end{array}$ \\
\hline CashAssets & $\begin{array}{c}0.782 * * * \\
(0.131)\end{array}$ & $\begin{array}{c}1.687 * * * \\
(0.344)\end{array}$ & $\begin{array}{l}0.343 * \\
(0.182)\end{array}$ & $\begin{array}{c}1.380 * * * \\
(0.240)\end{array}$ & $\begin{array}{c}0.834 * * * \\
(0.212)\end{array}$ & $\begin{array}{c}0.831 * * * \\
(0.138)\end{array}$ \\
\hline Leverage & $\begin{array}{c}0.075 \\
(0.115)\end{array}$ & $\begin{array}{l}-0.016 \\
(0.170)\end{array}$ & $\begin{array}{c}0.229 \\
(0.155)\end{array}$ & $\begin{array}{c}0.125 \\
(0.162)\end{array}$ & $\begin{array}{l}0.279^{*} \\
(0.168)\end{array}$ & $\begin{array}{c}-0.249 * * \\
(0.098)\end{array}$ \\
\hline$R O A$ & $\begin{array}{c}0.188 \\
(0.127)\end{array}$ & $\begin{array}{l}0.812 * \\
(0.415)\end{array}$ & $\begin{array}{c}0.426 * * * \\
(0.162)\end{array}$ & $\begin{array}{c}0.012 \\
(0.450)\end{array}$ & $\begin{array}{c}0.248 \\
(0.204)\end{array}$ & $\begin{array}{c}0.168 \\
(0.138)\end{array}$ \\
\hline TobinQ & $\begin{array}{c}0.149 * * * \\
(0.012)\end{array}$ & $\begin{array}{c}0.064 * * * \\
(0.018)\end{array}$ & $\begin{array}{c}0.140 * * * \\
(0.015)\end{array}$ & $\begin{array}{c}0.096 * * * \\
(0.018)\end{array}$ & $\begin{array}{c}0.136^{* * *} \\
(0.019)\end{array}$ & $\begin{array}{c}0.120 * * * \\
(0.011)\end{array}$ \\
\hline Hindex & $\begin{array}{l}0.390 * \\
(0.216)\end{array}$ & $\begin{array}{c}0.059 \\
(0.195)\end{array}$ & $\begin{array}{c}0.259 \\
(0.301)\end{array}$ & $\begin{array}{l}-0.168 \\
(0.197)\end{array}$ & $\begin{array}{c}0.852 * * * \\
(0.314)\end{array}$ & $\begin{array}{c}0.137 \\
(0.135)\end{array}$ \\
\hline Hindex Squared & $\begin{array}{l}-0.645^{*} \\
(0.338)\end{array}$ & $\begin{array}{l}-0.486^{*} \\
(0.249)\end{array}$ & $\begin{array}{l}-0.080 \\
(0.479)\end{array}$ & $\begin{array}{l}-0.273 \\
(0.274)\end{array}$ & $\begin{array}{c}-1.269 * * \\
(0.495)\end{array}$ & $\begin{array}{c}-0.447 * * \\
(0.182)\end{array}$ \\
\hline InstOwn & $\begin{array}{c}-1.014 * * * \\
(0.110)\end{array}$ & $\begin{array}{l}-0.056 \\
(0.096)\end{array}$ & $\begin{array}{c}-1.533 * * * \\
(0.221)\end{array}$ & $\begin{array}{l}-0.101 \\
(0.092)\end{array}$ & $\begin{array}{c}-0.949 * * * \\
(0.142)\end{array}$ & $\begin{array}{c}-0.441 * * * \\
(0.084)\end{array}$ \\
\hline LnAge & $\begin{array}{c}-1.386 * * * \\
(0.184)\end{array}$ & $\begin{array}{l}-0.093 \\
(0.300)\end{array}$ & $\begin{array}{c}-1.495^{* * *} \\
(0.290)\end{array}$ & $\begin{array}{l}-0.332 \\
(0.363)\end{array}$ & $\begin{array}{c}-1.219 * * * \\
(0.315)\end{array}$ & $\begin{array}{c}-0.887 * * * \\
(0.166)\end{array}$ \\
\hline PPEAssets & $\begin{array}{c}1.794 * * * \\
(0.187)\end{array}$ & $\begin{array}{c}0.847 * * * \\
(0.213)\end{array}$ & $\begin{array}{c}1.452 * * * \\
(0.250)\end{array}$ & $\begin{array}{c}1.238 * * * \\
(0.178)\end{array}$ & $\begin{array}{c}1.650 * * * \\
(0.208)\end{array}$ & $\begin{array}{c}1.613 * * * \\
(0.140)\end{array}$ \\
\hline LnSales & $\begin{array}{c}-0.587 * * * \\
(0.030)\end{array}$ & $\begin{array}{c}-0.620 * * * \\
(0.057)\end{array}$ & $\begin{array}{c}-0.501 * * * \\
(0.048)\end{array}$ & $\begin{array}{c}-0.506 * * * \\
(0.065)\end{array}$ & $\begin{array}{c}-0.667 * * * \\
(0.048)\end{array}$ & $\begin{array}{c}-0.640 * * * \\
(0.028)\end{array}$ \\
\hline MSA Prices & $\begin{array}{l}14.890 * \\
(8.432)\end{array}$ & $\begin{array}{c}4.968 \\
(5.068)\end{array}$ & $\begin{array}{c}13.306 * * * \\
(3.279)\end{array}$ & $\begin{array}{c}-34.187 * * \\
(15.651)\end{array}$ & $\begin{array}{l}7.145^{*} \\
(4.076)\end{array}$ & $\begin{array}{c}6.936 * * * \\
(2.189)\end{array}$ \\
\hline $\begin{array}{l}\text { Init. Controls } \times \\
\text { RePrice }\end{array}$ & YES & YES & YES & YES & YES & YES \\
\hline Firm FE & YES & YES & YES & YES & YES & YES \\
\hline Year FE & YES & YES & YES & YES & YES & YES \\
\hline Test "C. $=\mathrm{U} . "$ & \multicolumn{2}{|c|}{$7.24 * * *$} & \multicolumn{2}{|c|}{$6.95 * * *$} & \multicolumn{2}{|c|}{$14.48 * * *$} \\
\hline Observations & 5,901 & 4,551 & 3,352 & 3,410 & 3,566 & 7,810 \\
\hline Adjusted $\mathrm{R}^{2}$ & 0.849 & 0.915 & 0.739 & 0.876 & 0.867 & 0.907 \\
\hline
\end{tabular}


Panel D: Cash holdings

\begin{tabular}{|c|c|c|c|c|}
\hline \multirow[t]{3}{*}{ Dep. Var } & \multicolumn{2}{|c|}{$\operatorname{LnPat}_{t+1 \sim t+5}$} & \multicolumn{2}{|c|}{ LnCitePat $_{t+1 \sim t+5}$} \\
\hline & Low cash & High cash & Low cash & High cash \\
\hline & (1) & (2) & (3) & (4) \\
\hline \multirow[t]{2}{*}{ ReValue } & $0.934 * * *$ & 0.366 & $1.145 * * *$ & 0.222 \\
\hline & $(0.166)$ & $(0.243)$ & $(0.217)$ & $(0.203)$ \\
\hline \multirow[t]{2}{*}{ CashAssets } & $0.907 * * *$ & $0.798 * * *$ & $0.727 * * *$ & $0.995 * * *$ \\
\hline & $(0.190)$ & $(0.257)$ & $(0.224)$ & $(0.221)$ \\
\hline \multirow{2}{*}{ Leverage } & 0.074 & -0.202 & 0.063 & -0.001 \\
\hline & $(0.144)$ & $(0.190)$ & $(0.181)$ & $(0.170)$ \\
\hline \multirow[t]{2}{*}{$R O A$} & 0.051 & $0.801 * *$ & 0.257 & $0.493 *$ \\
\hline & $(0.170)$ & $(0.349)$ & $(0.197)$ & $(0.291)$ \\
\hline \multirow[t]{2}{*}{ TobinQ } & $0.104 * * *$ & $0.107 * * *$ & $0.137 * * *$ & $0.122 * * *$ \\
\hline & $(0.017)$ & $(0.018)$ & $(0.021)$ & $(0.016)$ \\
\hline \multirow[t]{2}{*}{ Hindex } & -0.061 & -0.031 & 0.138 & -0.073 \\
\hline & $(0.197)$ & $(0.298)$ & $(0.241)$ & $(0.220)$ \\
\hline \multirow[t]{2}{*}{ Hindex Squared } & 0.177 & -0.021 & -0.360 & -0.345 \\
\hline & $(0.294)$ & $(0.413)$ & $(0.373)$ & $(0.271)$ \\
\hline \multirow[t]{2}{*}{ InstOwn } & -0.190 & $-0.498 * * *$ & $-0.542 * *$ & $-0.355 * * *$ \\
\hline & $(0.205)$ & $(0.132)$ & $(0.252)$ & $(0.103)$ \\
\hline \multirow[t]{2}{*}{ LnAge } & -0.075 & 0.060 & -0.338 & $-0.943 * * *$ \\
\hline & $(0.258)$ & $(0.313)$ & $(0.297)$ & $(0.271)$ \\
\hline \multirow[t]{2}{*}{ PPEAssets } & $0.954 * * *$ & $1.907 * * *$ & $1.034 * * *$ & $1.953 * * *$ \\
\hline & $(0.214)$ & $(0.263)$ & $(0.249)$ & $(0.265)$ \\
\hline \multirow[t]{2}{*}{ LnSales } & $-0.707 * * *$ & $-0.611 * * *$ & $-0.679 * * *$ & $-0.624 * * *$ \\
\hline & $(0.053)$ & $(0.051)$ & $(0.061)$ & $(0.047)$ \\
\hline \multirow[t]{2}{*}{ MSA Prices } & -9.585 & $-23.810 * * *$ & 40.543 & $-6.192 * *$ \\
\hline & $(14.571)$ & (3.890) & $(27.137)$ & $(2.582)$ \\
\hline \multicolumn{5}{|l|}{ Init. Controls $\times$} \\
\hline RePrice & YES & YES & YES & YES \\
\hline Firm FE & YES & YES & YES & YES \\
\hline Year FE & YES & YES & YES & YES \\
\hline Test "Low=High" & \multicolumn{2}{|c|}{$4.39 * * *$} & \multicolumn{2}{|c|}{$5.66^{* * *}$} \\
\hline Observations & 3,184 & 3,617 & 3,184 & 3,617 \\
\hline Adjusted R2 & 0.885 & 0.859 & 0.851 & 0.912 \\
\hline
\end{tabular}


Panel E: Local real estate price volatility

\begin{tabular}{|c|c|c|c|c|}
\hline \multirow[t]{3}{*}{ Dep. Var } & \multicolumn{2}{|c|}{ LnPat $_{t+1 \sim t+5}$} & \multicolumn{2}{|c|}{ LnCitePat $t_{+1 \sim t^{+} 5}$} \\
\hline & Low volatility & High volatility & Low volatility & High volatility \\
\hline & (1) & (2) & (3) & (4) \\
\hline \multirow[t]{2}{*}{ ReValue } & $1.232 * * *$ & $0.451^{* * *}$ & $1.569 * * *$ & 0.344 \\
\hline & $(0.172)$ & $(0.155)$ & $(0.272)$ & $(0.281)$ \\
\hline \multirow[t]{2}{*}{ CashAssets } & $0.739 * * *$ & $0.908 * * *$ & $0.804 * * *$ & $1.181^{* * *}$ \\
\hline & $(0.148)$ & $(0.167)$ & $(0.258)$ & $(0.255)$ \\
\hline \multirow[t]{2}{*}{ Leverage } & $-0.332 * * *$ & -0.000 & $-0.459 * *$ & -0.103 \\
\hline & $(0.109)$ & $(0.134)$ & $(0.186)$ & $(0.224)$ \\
\hline \multirow[t]{2}{*}{$R O A$} & 0.129 & $0.365^{* *}$ & 0.315 & -0.035 \\
\hline & $(0.155)$ & $(0.152)$ & $(0.240)$ & $(0.238)$ \\
\hline \multirow[t]{2}{*}{ TobinQ } & $0.105^{* * *}$ & $0.127 * * *$ & $0.179 * * *$ & $0.152 * * *$ \\
\hline & $(0.013)$ & $(0.010)$ & $(0.020)$ & $(0.017)$ \\
\hline \multirow[t]{2}{*}{ Hindex } & 0.071 & -0.011 & 0.327 & -0.173 \\
\hline & $(0.180)$ & $(0.208)$ & $(0.295)$ & $(0.359)$ \\
\hline \multirow[t]{2}{*}{ Hindex Squared } & -0.181 & 0.361 & $-0.727^{*}$ & 0.437 \\
\hline & $(0.273)$ & $(0.305)$ & $(0.415)$ & $(0.523)$ \\
\hline \multirow[t]{2}{*}{ InstOwn } & $-0.351 * * *$ & $-0.840 * * *$ & $-0.635^{* * *}$ & $-1.203 * * *$ \\
\hline & $(0.105)$ & $(0.118)$ & $(0.181)$ & $(0.221)$ \\
\hline \multirow[t]{2}{*}{ LnAge } & 0.011 & $-0.739 * * *$ & -0.393 & $-1.728 * * *$ \\
\hline & $(0.161)$ & $(0.203)$ & $(0.305)$ & $(0.332)$ \\
\hline \multirow[t]{2}{*}{ PPEAssets } & $1.432 * * *$ & $1.604 * * *$ & $1.558 * * *$ & $2.021 * * *$ \\
\hline & $(0.163)$ & $(0.149)$ & $(0.270)$ & $(0.249)$ \\
\hline \multirow[t]{2}{*}{ LnSales } & $-0.546 * * *$ & $-0.642 * * *$ & $-0.609^{* * *}$ & $-0.704 * * *$ \\
\hline & $(0.038)$ & $(0.029)$ & $(0.058)$ & $(0.046)$ \\
\hline \multirow[t]{2}{*}{ MSA Prices } & -7.834 & $9.015^{* *}$ & 14.353 & $16.149^{* * *}$ \\
\hline & $(6.851)$ & $(3.951)$ & $(11.238)$ & $(5.653)$ \\
\hline \multicolumn{5}{|l|}{ Init. Controls $\times$} \\
\hline RePrice & YES & YES & YES & YES \\
\hline Firm FE & YES & YES & YES & YES \\
\hline Year FE & YES & YES & YES & YES \\
\hline Test "Low=High" & \multicolumn{2}{|c|}{$12.1 * * *$} & \multicolumn{2}{|c|}{$14.15^{* * *}$} \\
\hline Observations & 6,087 & 5,289 & 6,087 & 5,289 \\
\hline Adjusted R2 & 0.881 & 0.862 & 0.799 & 0.786 \\
\hline
\end{tabular}




\section{Internet Appendix for \\ "Managing innovation: The role of collateral"}

This internet appendix provides robustness tests and supplemental analyses to the main results presented in "Managing innovation: The role of collateral".

Table A1

Collateral shocks and financing behavior

This table presents the effect of collateral shocks on capital structure. The estimates are from IV regressions. The dependent variables are NetLtDebt (column 1), StIssue (column 2), LtSecureD (column 3), LtUnsecureD (column 4), NetStkIssue (column 5), NetFinancing (column 6). All the independent variables are lagged by one year except ReValue, CashAssets, and MSA Prices. Init. Controls $\times$ RePrice are fixed effects computed as firm-level initial characteristics (five quintiles of age, asset, ROA, two-digit industry, and state of headquarter location) interacted with industrial commercial real estate prices. Definitions of variables are in Appendix. In the IV specifications, standard errors are bootstrapped within MSA-year level, and are displayed in parentheses. ${ }^{* * *}, * *$, and $*$ indicate significance at the $1 \%, 5 \%$, and $10 \%$ level, respectively.

\begin{tabular}{lcccccc}
\hline Dep. Var. & $\begin{array}{c}\text { NetLtIssue } \\
(1)\end{array}$ & $\begin{array}{c}\text { NetStIssue } \\
(2)\end{array}$ & $\begin{array}{c}\text { LtSecureD } \\
(3)\end{array}$ & $\begin{array}{c}\text { LtUnsecureD } \\
(4)\end{array}$ & $\begin{array}{c}\text { NetStkIssue } \\
(5)\end{array}$ & $\begin{array}{c}\text { NetFinancing } \\
(6)\end{array}$ \\
\hline & & & & & & \\
ReValue & $0.027^{* * *}$ & $0.011^{* * *}$ & $0.023^{* *}$ & $-0.067^{* * *}$ & 0.008 & $0.005^{* * *}$ \\
& $(0.007)$ & $(0.002)$ & $(0.009)$ & $(0.010)$ & $(0.011)$ & $(0.001)$ \\
CashAssets & $-0.019^{* * *}$ & $-0.009^{* * *}$ & $-0.010^{*}$ & $-0.042^{* * *}$ & $-0.083^{* * *}$ & $-0.020^{* * *}$ \\
& $(0.006)$ & $(0.002)$ & $(0.006)$ & $(0.009)$ & $(0.014)$ & $(0.002)$ \\
TobinQ & $0.006^{* * *}$ & $0.001^{* * *}$ & -0.000 & $0.003^{* * *}$ & $0.030^{* * *}$ & $0.004^{* * *}$ \\
& $(0.001)$ & $(0.000)$ & $(0.001)$ & $(0.001)$ & $(0.002)$ & $(0.000)$ \\
MSA Prices & $0.682^{* *}$ & $0.071^{*}$ & $-0.622^{*}$ & $0.599^{*}$ & $-0.725^{* * *}$ & $-0.039^{* * *}$ \\
& $(0.328)$ & $(0.038)$ & $(0.323)$ & $(0.348)$ & $(0.245)$ & $(0.013)$ \\
Init. Controls & YES & YES & YES & YES & YES & YES \\
$\times$ RePrice & & & & & & \\
Firm FE & YES & YES & YES & YES & YES & YES \\
Year FE & YES & YES & YES & YES & YES & YES \\
Observations & 12,152 & 12,949 & 11,931 & 11,919 & 11,515 & 10,827 \\
Adjusted R ${ }^{2}$ & 0.074 & -0.002 & 0.503 & 0.555 & 0.449 & 0.548 \\
\hline
\end{tabular}




\section{Table A2}

Robustness checks

This table reports the robustness checks of the effect of collateral shocks on the innovation. The dependent variable is $\operatorname{LnPat}_{t+1 \sim t+5}$ in column (1) - (2), and LnCitePat $t_{t+1 \sim t+5}$ in column (3) - (4). Panel A examines whether the effects are driven by firms with their headquarters located in Massachusetts or California. Column (1) and column (3) are regressions on firms with their headquarters not located in Massachusetts or California, and column (2) and column (4) are regressions on firms with their headquarters located in Massachusetts or California. Panel B reports the effects of collateral on small firms in large cities, and large firms in small cities respectively. Column (1) and column (3) report regressions on small firms in large cities, and column (2) and column (4) report regressions on large firms in small cities. Panel C reports sub-period results. Column (1) and (3) are for the period from 1993 to 2000, and column (2) and (4) are for the period from 2001 to 2009. Panel D reports results using ReOwn instead of ReValue in the independent variable list. Column (1) and (3) are OLS, and column (2) and (4) are IV regressions.

Definitions of variables are in Appendix. The regression estimates are based on IV regressions except for column (1) and column (3) in Panel D. For IV regressions, standard errors are bootstrapped within MSA-year level, and are displayed in parentheses. ***, **, and * indicate significance at the $1 \%, 5 \%$, and $10 \%$ level, respectively. 
Panel A

\begin{tabular}{|c|c|c|c|c|}
\hline \multirow[t]{3}{*}{ Dep. Var. } & \multicolumn{2}{|c|}{ LnPat $_{t+1 \sim t^{+} 5}$} & \multicolumn{2}{|c|}{ LnCitePat $_{t^{+1 \sim t+}+5}$} \\
\hline & No CA, MA & $\mathrm{CA}+\mathrm{MA}$ & No CA, MA & $\mathrm{CA}+\mathrm{MA}$ \\
\hline & (1) & (2) & (3) & (4) \\
\hline \multirow[t]{2}{*}{ ReValue } & $0.820 * * *$ & $0.463^{*}$ & $0.883 * * *$ & $0.635^{* *}$ \\
\hline & $(0.122)$ & $(0.236)$ & $(0.123)$ & $(0.272)$ \\
\hline \multirow[t]{2}{*}{ CashAssets } & $0.711 * * *$ & $0.976 * * *$ & $0.844 * * *$ & $0.801 * * *$ \\
\hline & $(0.108)$ & $(0.185)$ & $(0.132)$ & $(0.207)$ \\
\hline \multirow[t]{2}{*}{ Leverage } & $-0.208^{* *}$ & -0.153 & -0.131 & 0.025 \\
\hline & $(0.094)$ & $(0.141)$ & $(0.104)$ & $(0.149)$ \\
\hline \multirow[t]{2}{*}{$R O A$} & 0.156 & $0.395^{* *}$ & $0.267^{*}$ & 0.137 \\
\hline & $(0.119)$ & $(0.173)$ & $(0.137)$ & $(0.185)$ \\
\hline \multirow[t]{2}{*}{ Tobin $Q$} & $0.118 * * *$ & $0.136 * * *$ & $0.142 * * *$ & $0.132 * * *$ \\
\hline & $(0.010)$ & $(0.012)$ & $(0.012)$ & $(0.013)$ \\
\hline \multirow[t]{2}{*}{ Hindex } & 0.155 & -0.046 & $0.249^{*}$ & $0.550^{*}$ \\
\hline & $(0.151)$ & $(0.280)$ & $(0.143)$ & $(0.286)$ \\
\hline \multirow[t]{2}{*}{ Hindex Squared } & -0.256 & 0.237 & $-0.586^{* * *}$ & $-0.824^{*}$ \\
\hline & $(0.222)$ & $(0.451)$ & $(0.188)$ & $(0.432)$ \\
\hline \multirow[t]{2}{*}{ InstOwn } & $-0.372 * * *$ & $-1.062 * * *$ & $-0.413 * * *$ & $-1.042 * * *$ \\
\hline & $(0.083)$ & $(0.105)$ & $(0.088)$ & $(0.121)$ \\
\hline \multirow[t]{2}{*}{ LnAge } & 0.124 & $-0.889 * * *$ & $-0.592 * * *$ & $-1.990^{* * *}$ \\
\hline & $(0.135)$ & $(0.190)$ & $(0.157)$ & $(0.235)$ \\
\hline \multirow[t]{2}{*}{ PPEAssets } & $1.488 * * *$ & $1.472 * * *$ & $1.442 * * *$ & $1.836^{* * *}$ \\
\hline & $(0.119)$ & $(0.201)$ & $(0.143)$ & $(0.245)$ \\
\hline \multirow[t]{2}{*}{ LnSales } & $-0.627 * * *$ & $-0.561 * * *$ & $-0.694 * * *$ & $-0.579 * * *$ \\
\hline & $(0.031)$ & $(0.034)$ & $(0.037)$ & $(0.029)$ \\
\hline \multirow[t]{2}{*}{ MSA Prices } & -10.142 & 8.023 & $9.343 * *$ & $9.354 * *$ \\
\hline & $(6.476)$ & $(5.243)$ & $(4.752)$ & $(4.467)$ \\
\hline Init. Controls $\times$ RePrice & YES & YES & YES & YES \\
\hline Firm FE & YES & YES & YES & YES \\
\hline Year FE & YES & YES & YES & YES \\
\hline Observations & 8,007 & 3,369 & 8,007 & 3,369 \\
\hline Adjusted $\mathrm{R}^{2}$ & 0.877 & 0.819 & 0.903 & 0.855 \\
\hline
\end{tabular}


Panel B

\begin{tabular}{|c|c|c|c|c|}
\hline \multirow[t]{3}{*}{ Dep. Var. } & \multicolumn{2}{|c|}{$\operatorname{LnPat}_{t+1 \sim t+5}$} & \multicolumn{2}{|c|}{ LnCitePat $_{t+1 \sim t+5}$} \\
\hline & Small Firm & Large Firm & Small Firm & Large Firm \\
\hline & (1) & (2) & (3) & (4) \\
\hline \multirow[t]{2}{*}{ ReValue } & $0.506^{* * *}$ & $0.651^{*}$ & $0.913^{* * *}$ & $1.847 * * *$ \\
\hline & $(0.156)$ & $(0.382)$ & $(0.163)$ & $(0.413)$ \\
\hline \multirow[t]{2}{*}{ CashAssets } & $0.869 * * *$ & $1.492 * * *$ & $0.691 * * *$ & $1.306 * * *$ \\
\hline & $(0.140)$ & $(0.444)$ & $(0.169)$ & $(0.400)$ \\
\hline \multirow[t]{2}{*}{ Leverage } & -0.018 & $-0.645^{* *}$ & 0.010 & $-0.631 * *$ \\
\hline & $(0.110)$ & $(0.290)$ & $(0.119)$ & $(0.263)$ \\
\hline \multirow[t]{2}{*}{$R O A$} & $0.304^{* *}$ & -0.470 & 0.193 & 0.185 \\
\hline & $(0.135)$ & $(0.722)$ & $(0.149)$ & $(0.627)$ \\
\hline \multirow[t]{2}{*}{ Tobin $Q$} & $0.145 * * *$ & $0.094 * * *$ & $0.139 * * *$ & $0.085^{* *}$ \\
\hline & $(0.011)$ & $(0.035)$ & $(0.013)$ & $(0.037)$ \\
\hline \multirow[t]{2}{*}{ Hindex } & 0.171 & 0.039 & 0.132 & $0.920 * * *$ \\
\hline & $(0.198)$ & $(0.369)$ & $(0.181)$ & $(0.303)$ \\
\hline \multirow[t]{2}{*}{ Hindex Squared } & -0.197 & -0.270 & -0.284 & $-1.552 * * *$ \\
\hline & $(0.306)$ & $(0.528)$ & $(0.275)$ & $(0.455)$ \\
\hline \multirow[t]{2}{*}{ InstOwn } & $-0.721 * * *$ & -0.339 & $-0.698^{* * *}$ & 0.279 \\
\hline & $(0.109)$ & $(0.224)$ & $(0.122)$ & $(0.228)$ \\
\hline \multirow[t]{2}{*}{ LnAge } & $-0.323^{*}$ & 0.226 & $-1.489 * * *$ & $-0.816^{* *}$ \\
\hline & $(0.174)$ & $(0.484)$ & $(0.216)$ & $(0.359)$ \\
\hline \multirow[t]{2}{*}{ PPEAssets } & $1.466 * * *$ & $0.844 * * *$ & $1.714 * * *$ & $1.083 * * *$ \\
\hline & $(0.156)$ & $(0.326)$ & $(0.185)$ & $(0.367)$ \\
\hline \multirow[t]{2}{*}{ LnSales } & $-0.626 * * *$ & $-0.516 * * *$ & $-0.653 * * *$ & $-0.319 * * *$ \\
\hline & $(0.033)$ & $(0.097)$ & $(0.038)$ & $(0.104)$ \\
\hline \multirow[t]{2}{*}{ MSA Prices } & $6.493 * *$ & $-26.117 *$ & $10.995 * * *$ & -8.579 \\
\hline & $(3.040)$ & $(15.800)$ & $(2.645)$ & $(9.267)$ \\
\hline Init. Controls $\times$ RePrice & YES & YES & YES & YES \\
\hline Firm FE & YES & YES & YES & YES \\
\hline Year FE & YES & YES & YES & YES \\
\hline Observations & 5,300 & 1,119 & 5,300 & 1,119 \\
\hline Adjusted $\mathrm{R}^{2}$ & 0.873 & 0.852 & 0.903 & 0.838 \\
\hline
\end{tabular}


Panel C

\begin{tabular}{|c|c|c|c|c|}
\hline \multirow[t]{3}{*}{ Dep. Var. } & \multicolumn{2}{|c|}{$\operatorname{LnPat}_{t+1 \sim t^{+} 5}$} & \multicolumn{2}{|c|}{ LnCitePat $_{t+1 \sim t+5}$} \\
\hline & $1993-2000$ & $2001-2009$ & $1993-2000$ & $2001-2009$ \\
\hline & (1) & (2) & (3) & (4) \\
\hline \multirow[t]{2}{*}{ ReValue } & $0.834 * * *$ & $1.472 * * *$ & $0.894 * * *$ & $1.318 * * *$ \\
\hline & $(0.112)$ & $(0.361)$ & $(0.143)$ & $(0.152)$ \\
\hline \multirow[t]{2}{*}{ CashAssets } & $0.689 * * *$ & $0.746 * * *$ & $0.683 * * *$ & $0.805 * * *$ \\
\hline & $(0.116)$ & $(0.205)$ & $(0.148)$ & $(0.191)$ \\
\hline \multirow[t]{2}{*}{ Leverage } & $-0.191 * *$ & 0.028 & -0.048 & 0.186 \\
\hline & $(0.086)$ & $(0.218)$ & $(0.114)$ & $(0.151)$ \\
\hline \multirow[t]{2}{*}{$R O A$} & $0.378 * * *$ & 0.138 & $0.357^{* *}$ & -0.023 \\
\hline & $(0.102)$ & $(0.203)$ & $(0.142)$ & $(0.182)$ \\
\hline \multirow[t]{2}{*}{ Tobin $Q$} & $0.095 * * *$ & $0.076 * * *$ & $0.109 * * *$ & $0.090 * * *$ \\
\hline & $(0.008)$ & $(0.021)$ & $(0.011)$ & $(0.019)$ \\
\hline \multirow[t]{2}{*}{ Hindex } & 0.053 & 0.172 & $0.299 *$ & -0.029 \\
\hline & $(0.154)$ & $(0.191)$ & $(0.161)$ & $(0.171)$ \\
\hline \multirow[t]{2}{*}{ Hindex Squared } & -0.007 & -0.200 & $-0.503 * *$ & -0.049 \\
\hline & $(0.237)$ & $(0.308)$ & $(0.240)$ & $(0.242)$ \\
\hline \multirow[t]{2}{*}{ InstOwn } & $-0.465 * * *$ & $-0.498 * *$ & $-0.540 * * *$ & -0.117 \\
\hline & $(0.099)$ & $(0.202)$ & $(0.107)$ & $(0.109)$ \\
\hline \multirow[t]{2}{*}{ LnAge } & $-0.443 * * *$ & $2.155^{* *}$ & $-1.179 * * *$ & 0.480 \\
\hline & $(0.137)$ & $(0.846)$ & $(0.173)$ & $(0.513)$ \\
\hline \multirow[t]{2}{*}{ PPEAssets } & $1.688 * * *$ & $0.735^{* *}$ & $1.783 * * *$ & $1.138 * * *$ \\
\hline & $(0.104)$ & $(0.347)$ & $(0.141)$ & $(0.364)$ \\
\hline \multirow[t]{2}{*}{ LnSales } & $-0.586 * * *$ & $-0.281 * * *$ & $-0.607 * * *$ & $-0.319 * * *$ \\
\hline & $(0.027)$ & $(0.063)$ & $(0.031)$ & $(0.060)$ \\
\hline \multirow[t]{2}{*}{ MSA Prices } & $-10.720 * *$ & 6.521 & $11.385^{* * *}$ & -0.662 \\
\hline & $(5.109)$ & $(9.243)$ & $(4.110)$ & $(9.513)$ \\
\hline Init. Controls $\times$ RePrice & YES & YES & YES & YES \\
\hline Firm FE & YES & YES & YES & YES \\
\hline Year FE & YES & YES & YES & YES \\
\hline Observations & 8,486 & 2,890 & 8,486 & 2,890 \\
\hline Adjusted $\mathrm{R}^{2}$ & 0.887 & 0.915 & 0.882 & 0.969 \\
\hline
\end{tabular}


Panel D

\begin{tabular}{|c|c|c|c|c|}
\hline \multirow[t]{3}{*}{ Dep.Var. } & \multicolumn{2}{|c|}{ LnPat $_{t+1 \sim t+5}$} & \multicolumn{2}{|c|}{ LnCitePat $_{t+1 \sim t+5}$} \\
\hline & OLS & IV & OLS & IV \\
\hline & (1) & (2) & (3) & (4) \\
\hline \multirow[t]{2}{*}{ ReOwn } & $1.218 * * *$ & $1.168 * * *$ & $0.897 * * *$ & $0.787 * *$ \\
\hline & $(0.289)$ & $(0.324)$ & $(0.309)$ & $(0.364)$ \\
\hline \multirow[t]{2}{*}{ CashAssets } & $0.896 * * *$ & $0.881 * * *$ & $0.905 * * *$ & $0.896 * * *$ \\
\hline & $(0.100)$ & $(0.099)$ & $(0.119)$ & $(0.117)$ \\
\hline \multirow[t]{2}{*}{ Leverage } & $-0.168 * *$ & $-0.188 * *$ & -0.110 & -0.105 \\
\hline & $(0.076)$ & $(0.076)$ & $(0.084)$ & $(0.084)$ \\
\hline \multirow[t]{2}{*}{$R O A$} & $0.283 * * *$ & $0.298 * * *$ & $0.252 * *$ & $0.263 * *$ \\
\hline & $(0.098)$ & $(0.096)$ & $(0.114)$ & $(0.113)$ \\
\hline \multirow[t]{2}{*}{ TobinQ } & $0.124 * * *$ & $0.125 * * *$ & $0.134 * * *$ & $0.136 * * *$ \\
\hline & $(0.008)$ & $(0.008)$ & $(0.009)$ & $(0.009)$ \\
\hline \multirow[t]{2}{*}{ Hindex } & 0.100 & 0.059 & $0.296 * *$ & $0.294 * *$ \\
\hline & $(0.132)$ & $(0.133)$ & $(0.131)$ & $(0.130)$ \\
\hline \multirow[t]{2}{*}{ Hindex Squared } & -0.127 & -0.025 & $-0.581 * * *$ & $-0.575 * * *$ \\
\hline & $(0.201)$ & $(0.200)$ & $(0.180)$ & $(0.177)$ \\
\hline \multirow[t]{2}{*}{ InstOwn } & $-0.558 * * *$ & $-0.590 * * *$ & $-0.655^{* * *}$ & $-0.649 * * *$ \\
\hline & $(0.076)$ & $(0.078)$ & $(0.075)$ & $(0.078)$ \\
\hline \multirow[t]{2}{*}{ LnAge } & $-0.299 * * *$ & -0.089 & $-0.773 * * *$ & $-0.894 * * *$ \\
\hline & $(0.104)$ & $(0.125)$ & $(0.122)$ & $(0.147)$ \\
\hline \multirow[t]{2}{*}{ PPEAssets } & $1.558 * * *$ & $1.612 * * *$ & $1.729 * * *$ & $1.725 * * *$ \\
\hline & $(0.102)$ & $(0.102)$ & $(0.120)$ & $(0.121)$ \\
\hline \multirow[t]{2}{*}{ LnSales } & $-0.654 * * *$ & $-0.654 * * *$ & $-0.710 * * *$ & $-0.712 * * *$ \\
\hline & $(0.022)$ & $(0.022)$ & $(0.025)$ & $(0.025)$ \\
\hline \multirow[t]{2}{*}{ MSA Prices } & $-11.392 * *$ & 1.622 & 6.003 & $15.142 * * *$ \\
\hline & $(4.679)$ & $(4.221)$ & $(4.613)$ & $(2.902)$ \\
\hline Init. Controls $\times$ RePrice & YES & YES & YES & YES \\
\hline Firm FE & YES & YES & YES & YES \\
\hline Year FE & YES & YES & YES & YES \\
\hline Observations & 11,539 & 11,539 & 11,539 & 11,539 \\
\hline Adjusted $\mathrm{R}^{2}$ & 0.864 & 0.866 & 0.892 & 0.893 \\
\hline
\end{tabular}

